\title{
RESUMOS DE DISSERTAÇÕES DE MESTRADO E TESES DE DOUTORADO APRESENTADAS NA FACULDADE DE MEDICINA DE RIBEIRÃO PRETO - USP DE JANEIRO A MARÇO DE 2010
}

\section{Biologia Celular e Molecular}

\section{EXPRESSÃO E PURIFICAÇÃO DAS TRIPTOFANIL TRNA SINTETASES DE Leishmania major}

\author{
André Luiz Vieira Zorzetto Fernandes \\ Orientador: Prof. Dr. Luiz Ricardo Orsini Tosi \\ Dissertação de Mestrado apresentada em 14/01/2010
}

As Aminoacil tRNA Sintetase (aaTRS) catalisam a aminoacilação de aminoácidos e a ligação subsequente deste aminoacil ácido a seu respectivo tRNA. Em humanos, além do seu papel na ativação do aminoácido, a Triptofanil tRNA Sintetase (TrpTRS) foi caracterizada como um inibidor da angiogênese após sofrer proteólise por elastase de leucócito.

O genoma de Leishmania major codifica duas TrpTRSs diferentes, uma forma mitocondrial (TrpTRS1) e uma forma citosólica (TrpTRS2). Os genes das TrpTRS1 e 2 foram amplificados a partir de DNA genômico de LV39 e clonados no vetor pET28a. As proteínas foram expressas como corpo de inclusão em Rosetta (DE3) após indução com 0,5mM de IPTG por 4 horas à $37^{\circ} \mathrm{C}$. Esses corpos de inclusão se mostraram passíveis de solubilização por $8 \mathrm{M}$ uréia ou 1,5\% sarcosil, e, após purificação por lavagem do corpo de inclusão foi possível obter as proteínas puras com atividade de aminoacilação e estrutura secundária quando estas eram solubilizadas com detergente. O uso de cromatografia de afinidade em NiSepharose só foi possível após solubilização por uréia.

Foram geradas linhagens de L. major com expressão aumentada para os genes TrpTRS1 e TrpTRS2 assim como uma linhagem heterozigota para TrpTRS2. Essas linhagens foram utilizadas em ensaios de infecção in vivo, no qual foi possível observar um papel das TrpTRSs na formação de lesão. Essas proteínas heterólogas também foram utilizadas na geração de anticorpos policlonais que permitiram confirmar a localização mitocondrial de TrpTRS1. Por experimento de Western blot foi possível caracterizar um possível processamento sofrido por TrpTRS2 envolvendo a perda da extremidade N-terminal.

\section{PROTEOMA DAS LINHAGENS CELULARES MELAN-A, TM1 E TM5: MODELO DE MELANOMA MURINO}

Nívea Maria Rocha Macedo

Orientador: Prof. Dr. José César Rosa

Tese de Doutorado apresentada em 29/01/ 2010

O presente trabalho investigou o proteoma das linhagens Melan-A, TM1 e TM5, um modelo murino de melanoma, por meio de Shotgun Proteomics e ensaios para caracterização das modificações pós-tradução fosforilação e O-GlcNAcilação. Das 84 proteínas identificadas por CID-MS/MS, foi observado que 49 proteínas foram encontradas nas 3 linhagens celulares estudadas, oito proteínas foram encontradas exclusivamente em Melan-A, três em TM1, seis em TM5 e três em TM1 e TM5. Das proteínas identificadas, cinquenta são tipicamente de citoplasma, nove de núcleo, dez de membrana, sete podem ser encontradas em citoplasma e membrana e uma apresenta localização extracelular. Assim, esses estudos contribuíram para o aumento do conhecimento sobre o proteoma dessas linhagens celulares, principalmente, em termos de identificação de proteínas que são um grande desafio em estudos proteômicos, como proteínas de membrana e proteínas básicas. Foram realizados ensaios para caracterização do O-GlcNAc-proteoma e do fosfoproteoma dessas linhagens celulares. Para traçar o perfil de proteínas modificadas por O-GlcNAc nos extratos celulares foi utilizado um anticorpo monoclonal anti-O-GlcNAc, sendo observadas 16 bandas protéicas com marcação positiva para O-GlcNAc nas linhagens estudadas, entretanto não foram observadas diferenças marcantes em termos de O-GlcNAcilação protéica entre as 3 linhagens celulares. Por meio de uma abordagem que utilizou SDS-PAGE/Western blotting foi observada uma marcação diferencial para proteínas modificadas por fosforilação em serina em relação àquelas modificadas por fosforilação em tirosina nas três linhagens celulares, porém as bandas detectadas por densitometria não demonstraram diferenças estatisticamente significantes. Embora existam distintas bandas que foram marcadas tanto para fosfoserina quanto para 
fosfotirosina, não existem marcantes diferenças no estado de fosforilação de proteínas entre Melan-A, TM1 e TM5. Quando fosfopeptídeos foram enriquecidos por precipitação e IMAC, foram identificadas por espectrometria de massas 223 fosfoproteínas. Destas 223 fosfoproteínas identificadas nas três linhagens celulares, 28 foram comuns a todas as três, 28 fosfoproteínas foram identificadas somente em TM1 e TM5, apenas 2 fosfoproteínas foram comuns à Melan-A e TM1 e 6 foram comuns à Melan-A e TM5. Foi observado que 169 fosfopeptídeos identificados contêm fosforilação em Ser ou Thr e, portanto, representam a maioria dos fosfopeptídeos detectados. Além disso, a maioria deles contém apenas um sítio, enquanto 15 sítios foram identificados em Tyr. Este resultado é completamente coerente com outros estudos similares descritos na literatura, uma vez que se estima que mais de $90 \%$ das fosforilações em células eucarióticas ocorrem em Ser e Thr. As fosfoproteínas identificadas em Melan-A, TM1 e TM5 foram agrupadas por função molecular e participação em processos biológicos através do programa GeneTools, que resultou em um agrupamento de fosfoproteínas ligantes de metais em TM1 e TM5 em relação a Melan-A e uma relação inversa quanto a fosfoproteínas funcionalmente envolvidas na adesão celular. Estudos da literatura indicam que células de melanoma são mais suscetíveis à intoxicação por metais do que melanócitos e a diminuição de fosfoproteínas envolvidas em adesão são congruentes com o fenótipo apresentado por TM1 e TM5, que é de perda de adesão e resistência a anoikis. A investigação realizada neste trabalho contribuiu para o estabelecimento de metodologia proteômica para os estudos de modificações pós-traducionais e também contribuiu para um melhor entendimento da biologia das células TM1 e TM5, transformadas em malignantes a partir de Melan-A, no sentido de compreender esse modelo murino de melanoma.

\title{
O PAPEL DAS GALECTINAS NO COMPORTAMENTO FUNCIONAL DOS MASTÓCITOS
}

\author{
Vanina Danuza Toso \\ Orientadora: Profa. Dra. Maria Célia Jamur \\ Dissertação de Mestrado apresentada em 03/02/2010
}

As galectinas têm um papel modulador em vários tipos celulares, regulando a adesão, migração, proliferação celular entre outros processos fisiológicos. Os mastócitos são células imunorreguladoras que participam dos mecanismos de defesa do organismo e são conhecidos por exercerem um papel fundamental na asma e em reações alérgicas, inflamatórias, bem como na eliminação de parasitas. A participação dos mastócitos nesses processos está relacionada com o seu recrutamento para diferentes tecidos, a sua migração, proliferação, adesão e liberação de seus mediadores químicos. O objetivo deste trabalho foi investigar o papel das galectinas-1 e 3 na fisiologia dos mastócitos, utilizando camundongos knockout para estas galectinas. Os resultados mostram que não existem diferenças no número de mastócitos no baço, pele e pulmão entre os camundongos knockout para galectina-1 (gal-1 $\left.1^{(-/)}\right)$e camundongos knockout para galectina-3 (gal-3 ${ }^{(-)}$ -) ) em comparação com camundongos selvagens. Entretanto, nossos resultados mostraram que após 3 e 4 semanas de cultivo o número de mastócitos derivados in vitro da medula óssea de camundongos gal-3 $3^{(-/)}$é bem menor quando comparado com camundongos gal- $1^{(-/)}$e selvagens. Os resultados também mostram que mastócitos derivados da medula óssea de camundongos gal-1 $1^{(-/)}$migram mais em relação aos mastócitos gal- $3^{(-/)}$e selvagens, na presença ou ausência dos fatores quimiotáticos IL-3 e SCF. Estes achados são confirmados pela presença de extensos lamelipódios e filopódios nestes mastócitos. Os experimentos in vivo, porém, mostram um maior recrutamento de mastócitos para a pele de camundongos gal-3 $3^{(-/)}$em comparação com camundongos gal-1 $1^{(-/)}$, após a injeção de IL-3. Por outro lado, a injeção de SCF induz um maior recrutamento para a pele de camundongos gal- $1^{(-/)}$em comparação com camundongos gal-1 $1^{(-/)}$. A adesão de mastócitos derivados da medula óssea de camundongos gal- $1^{(-/)}$, camundongos gal- $3^{(-/)}$e selvagem aos diferentes componentes da matriz extracelular (fibronectina, laminina, colágeno tipo I e colágeno tipo IV) foi semelhante. Portanto, as galectinas-1 e -3 influenciam a migração de mastócitos in vitro e modulam o recrutamento de mastócitos in vivo, mas não alteram o processo de adesão destas células aos diferentes componentes da matriz extracelular.

\section{ESTUDOS PROTEÔMICOS E CARACTERIZAÇÃO DA PROLIFERAÇÃO E MIGRAÇÃO CELULAR EM LINHAGENS CELULARES DEREIVADAS DE GBM ESTIMULADAS POR EGF}

\author{
Anelisa Ramão \\ Orientador: Prof. Dr. José Cesar Rosa \\ Dissertação de Mestrado apresentada em 05/02/2010
}

Glioma é um dos tipos mais comuns de tumor primário no SNC adulto. É classificado em quatro graus, dos quais o glioblastoma multiforme (GBM), grau IV, é o mais agressivo, com média de sobrevivência de até um ano após diagnóstico. 
Surge como consequência do acúmulo de mutações no genoma que provocam desregulação de inúmeras vias de sinalização intracelular, dentre as quais estão aquelas ativadas pelo receptor do fator de crescimento epidermal (EGFR). EGFR pertence a uma família de receptores tirosina-quinases relacionada a cascatas de sinalização intracelular que modulam a proliferação, sobrevivência, adesão, migração e diferenciação celular. O presente trabalho utilizou duas linhagens, U87MG e T98G, derivadas de glioblastoma multiforme para estudos proteômicos e funcionais sob estímulo de EGF. A abordagem proteômica utilizada baseou-se na separação das proteínas por eletroforese bidimensional e shotgun proteomics combinando eletroforese SDS-PAGE e cromatografia liquida em fase reversa (SDS-PAGE-LC-MS/MS). Os ensaios biológicos funcionais incluíram medidas da proliferação e migração celular. As linhagens T98G e U87MG possuem diferentes capacidades para a indução de formação de tumor em camundongos imunossuprimidos. A linhagem celular U87MG apresentou maior taxa de proliferação basal quando comparado a linhagem T98G, mas ambas foram pouco responsivas ao estímulo de EGF. A migração celular na linhagem U87MG também foi maior que em T98G sem estímulo, porém quando as células foram estimuladas por EGF, a linhagem T98G foi mais responsiva e apresentou aumento significativo na migração celular comparada a U87MG e foi seis vezes maior do que seu controle. A comparação de ambas as linhagens por técnicas proteômicas revelou a presença de proteínas relacionadas ao aumento de proliferação e migração/invasão celular, que estavam prevalentes nas células U87MG, sugerindo que elas possam contribuir para o fenótipo tumorigênico das células U87MG. Entre elas estão, a proteína 14-3-3 relacionada à proliferação celular e as proteínas anexina A1 e estatimina envolvidas na migração/ invasão celular. A análise proteômica por gel bidimensional e shotgun proteomics das duas linhagens estimuladas por EGF revelou proteínas envolvidas em vias metabólicas e em processos celulares que estão implicados na manutenção do tumor, tais como triosefosfato isomerase, alfa-enolase e superóxido dismutase. O fosfoproteoma das linhagens foi obtido a partir do enriquecimento dos fosfopeptídeos através de precipitação por fosfato de cálcio e coluna de afinidade por metal (IMAC). As fosfoproteínas identificadas estão envolvidas no metabolismo, tradução de sinais e processos biológicos como proliferação e migração celular. Alguns dos sítios fosforilados encontrados já foram citados na literatura. Entretanto, novos sítios de fosforilação foram demonstrados, os quais abrem perspectivas para estudos funcionais destas proteínas, bem como inferências sobre as enzimas quinases/fosfatases envolvidas nessas modificações pós-tradução, nos quais esses fosfopeptídeos são substratos. Além disso, o processo de enriquecimento de fosfopeptídeos permitiu a detecção de proteínas pouco abundantes que não foram detectados por gel bidimensional ou shotgun proteomics. Esse estudo abre novas perspectivas para investigações sobre a caracterização de mecanismos moleculares envolvidos na capacidade diferencial de U87MG e T98G induzirem a formação de tumores.

\title{
ESTUDOS SOBRE A INTERAÇÃO DE Leishmania RNA VIRUS 1-4 COM Leishmania (V) guyanensis
}

\author{
Marcus Vinícius Gomes da Silva \\ Orientador: Prof. Dr. Eurico de Arruda Neto \\ Dissertação de Mestrado apresentada em 26/02/2010
}

Leishmania virus (LRV) é um virus de RNA de fita dupla que infecta persistentemente algumas espécies de Leishmania, principalmente os da subespécie Viannia. Embora o impacto na saúde pública da leishmaniose nos trópicos seja significativa, muito pouco se sabe sobre os papéis possíveis, se houver, que LRV pode ter sobre a biologia da Leishmania, como por exemplo na infectividade e patogenicidade. Este estudo foi conduzido para avaliar a replicação de LRV1-4 durante o ciclo de crescimento de Leishmania (V.) guyanensis da cepa M4147, que é naturalmente infectada com LRV1-4 (M4147/LRV1-4). Cultivo de M4147/LRV1-4 em meio sólido permitiu o isolamento de um clone sem LRV1-4 (nomeado clone 40), que foi utilizado como controle negativo. Não houve diferença entre as curvas de crescimento de M4147/LRV1-4 e clone 40. A carga viral de LRV1-4 determinada por PCR em tempo real mostrou que não houve replicação viral durante a fase exponencial de crescimento do M4147/LRV1-4 no estado liquido, mas somente após a fase estacionária de Leishmania. Houve uma diminuição progressiva da carga de LRV 1-4 ao longo do tempo durante as passagens de M4147/LRV1-4 na cultura axênica. Comparação de infectividade de macrófagos peritoneais in vitro mostrou que o percentual de macrófagos infectados foi significativamente maior para M4147/LRV1-4 (51\%) do que para o clone 40 (28\%) em 96 horas após a infecção, mas não antes desse tempo. Não houve diferença significativa no número de amastigotas por macrófago infectado. O teste de patogenicidade em coxim plantar de hamster infectados com M4147/LRV1-4 e com o Clone 40 não apresentaram diferenças no tamanho da lesão. LRV1-4 replica-se lentamente em Leishmania (V.) guyanensis, sem efeito aparente sobre o ciclo de crescimento do parasita ou de sua patogenicidade na pata de hamster, porem sua presença aumentou a porcentagem de macrófagos peritoneais infectados ) in nitro, sem alteração da carga parasitária. 


\title{
O PAPEL DO RECEPTORES INTRACELULARES Nod1 E Nod2 NA RESISTÊNCIA CONTRA A INFECÇÃO POR Leishmania major
}

\author{
Eulália Maria Lima da Silva \\ Orientador: Prof. Dr. Dario Simões Zamboni \\ Dissertação de Mestrado apresentada em 26/03/2010
}

Os receptores da imunidade inata, como os receptores Toll-like (TLRs) têm um papel central no controle da infecção por Leishmania major, pois camundongos deficientes em MyD88 são altamente susceptíveis a infecção por este parasito. Recentemente, uma família de receptores intracelulares, conhecida como receptores Nod-like (NLRs), foi descoberta, e de

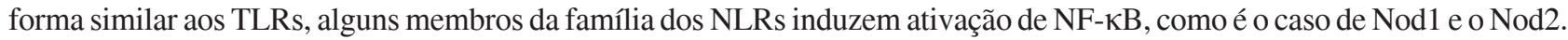
Nosso objetivo foi determinar se Nod1 e Nod2 são também capazes de reconhecer $L$. major. Para avaliar a ativação de NFКB em resposta a infecção por L. major, nós utilizamos um sistema de célula reporter que expressa o gene da luciferase

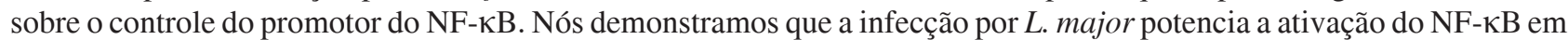
células HEK293 expressando transientemente Nod1 e Nod2. Para determinar o papel de Nod1 e Nod2 no reconhecimento do parasita pela célula hospedeira, nós usamos macrófagos de animais deficientes para Nod1, Nod2 e Rip2, uma quinase

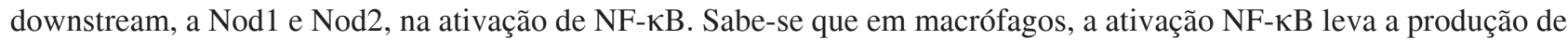
citocinas e a expressão de moléculas co-estimulatórias. Assim, demonstramos que macrófagos deficientes em Nod1 e Nod2 possuem reduzida expressão de moléculas co-estimulatórias, como CD80 e CD86, e deficiência na expressão de citocinas como IFN- $\gamma$ e IL-12. Adicionalmente, Nod1, Nod2 e Rip2 são requeridos para a produção de NO. Além disso, macrófagos deficientes para Nod1, Nod2 e Rip2, são mais permissivos a infecção por L. major. Experimentos realizados in vivo demonstram que Nod1 e Rip2 são importantes para o controle do desenvolvimento das lesões e para a restrição da multiplicação parasitária. Coletivamente nossos dados indicam que Nod1 e Nod2 são importantes sensores que operam no reconhecimento e contribuem para o controle da infecção por Leishmania major.

\section{Bioquímica}

\section{BIOPROSPECÇÃO E PRODUÇÃO DE ENZIMAS FIBROLÍTICAS POR Aspergillus japonicus COM POTENCIAL APLICAÇÃO EM NUTRIÇÃO DE RUMINANTES}

\author{
Fernanda Dell Antonio Facchini \\ Orientadora: Profa. Dra. Maria de Lourdes Teixeira de Moraes Polizeli \\ Dissertação de Mestrado apresentada em 26/03/2010
}

Um programa de bioprospecção em fungos filamentosos em ambientes de pastagens foi inicialmente aplicado neste trabalho com o objetivo de selecionar bons produtores de xilanase e CMCases. Dentre as amostras, foi selecionado o fungo Aspergillus japonicus Saito devido à alta produção destas enzimas, o qual foi cultivado em fermentação submersa (FSm, em meio SR) ou, em fermentação em estado sólido (FES) suplementados com resíduos agroindustriais para finalidade de aplicação em nutrição de ruminantes. Analisando os dados obtidos, pode-se concluir que as xilanases e celulases em estudo foram secretadas em maior quantidade a $30^{\circ} \mathrm{C}$, sendo produzidas a partir do terceiro e sexto dia de incubação em FES e, em FSm, no sexto e quinto dias em condições estáticas, respectivamente. Para ambas as enzimas, a densidade de inóculo adequada foi de 107 conídios/mL e as melhores misturas de fontes de carbono para que o fungo produzisse estas enzimas foram farelo de soja e sabugo de milho (1:3) para xilanase e farelo de trigo e bagaço de cana (3:1) para a CMCase em ambos os tipos de fermentação. A melhor fonte de nitrogênio foi a peptona, tanto em FES quanto em FSm, onde houve suplementação com os sais SR e Khanna no meio sólido para xilanase e celulase, respectivamente. Já em FSm o planejamento fatorial 23 indicou novas proporções de extrato de levedura, peptona e fonte de carbono para ambas as enzimas, acrescidos de sais SR. Ainda, o melhor $\mathrm{pH}$ inicial do meio de cultivo para a produção de celulase foi $\mathrm{pH} 4,0$ e para xilanase foi pH 5,0, em FSm e a presença de Tween 80 no meio líquido reduziu a produção das enzimas. Os ótimos de temperatura e $\mathrm{pH}$ de reação dos extratos brutos corresponderam a $60^{\circ} \mathrm{Ce} 55^{\circ} \mathrm{C}$ para xilanase e $\mathrm{CMCase}$, respectivamente em $\mathrm{pH} 4,0$ para ambas. A termoestabilidade da xilanase foi $100 \%$ até $40^{\circ} \mathrm{C}$, decaindo após esta temperatura, enquanto que a CMCase permaneceu com $70 \%$ de estabilidade até $60^{\circ} \mathrm{C}$ em $120 \mathrm{~min}$. Frente a diferentes $\mathrm{pHs}$, a xilanase e CMCase de A. japonicus mantiveram-se estáveis em pH de 4,0 a 7,0 e 5,0 e 6,0, respectivamente. A presença de $\mathrm{Cu}^{++}$e $\mathrm{Mn}^{++}$na reação aumentaram 
a atividade de xilanase e CMCase em $10 \%$ e 64\%, respectivamente. Os extratos obtidos não apresentaram caráter citotóxico. $\mathrm{Na}$ hidrólise de forrageiras, os extratos apresentaram melhor desempenho nos gêneros Brachiaria e nos testes in vitro realizados no setor de rações houve um aumento significativo na digestibilidade de diversas forrageiras, principalmente em cana-de-açúcar. Ainda, foi verificada uma maior liberação de gases na presença do preparado enzimático, sendo outro indicativo de maior digestibilidade. Nos testes in vivo, as xilanases mantiveram-se estáveis por até 4 horas dentro do rúmen de caprinos.

\title{
PARTICIPAÇÃO DAS CARBOXIPEPTIDASES DO PERFUSATO DO LEITO ARTERIAL MESENTÉRICO DE RATO NO PROCESSAMENTO DE ANGIOTENSINAS
}

\author{
Hugo Juarez Vieira Pereira \\ Orientador: Prof. Dr. Eduardo Brandt de Oliveira \\ Tese de Doutorado apresentada em 30/03/2010
}

O leito arterial mesentérico (LAM) é capaz de secretar algumas proteases solúveis que se acumulam no líquido de perfusão. Nosso laboratório tem se dedicado à caracterizar essas enzimas, entre elas, a elastase-2, anteriormente descrita como uma enzima unicamente digestiva, e, agora, apresentada também como a principal enzima formadora de Ang II no perfusato do LAM de rato. Além desta endopeptidase, atividades de carboxipeptidases foram detectadas neste perfusato, utilizando-se substratos sintéticos e vasopeptídeos, como o ZVF, a Ang I e a Bk. A atividade formadora de des-Arg9-Bk foi recentemente caracterizada como sendo a CPB1. Novamente, uma protease antes descrita unicamente como digestiva, foi encontrada processando vasopeptídeos no perfusato do LAM de rato. Assim, o objetivo deste trabalho foi determinar as enzimas capazes de agir sobre a região C-terminal de angiotensinas, clivando resíduos aromáticos e alifáticos. Inicialmente, as atividades tipo CPA do perfusato do LAM de rato foram separadas cromatograficamente em cinco picos distintos. Frações destes picos foram caracterizadas, determinando quais destas eram capazes de formar Ang 1-9 a partir de Ang I, e, Ang 1-7 a partir de Ang II. A atividade formadora de Ang 1-7 foi caracterizada com substratos e inibidores, e, mostrouse que não correspondia a nenhuma das enzimas formadoras de Ang 1-7 descritas, a saber, ECA2, prolilcarboxipeptidase e catepsina A. Em paralelo, isolamos a atividade formadora de Ang 1-9, utilizando-se uma cromatografia por troca iônica em coluna de DEAESepharose e três cromatografias por afinidade em Arg-Sepharose, PCI-Sepharose e SBTI-Sepharose. Após o isolamento, esta enzima foi digerida com tripsina e cinco de seus fragmentos trípticos foram sequenciados por espectrometria de massas, identificando-se essa enzima como sendo a CPA2, idêntica à pancreática. A enzima formadora de Ang 1-7 foi isolada por duas cromatografias de troca iônica, uma em DEAE-Sepharose e outra em Mono Q. Depois do isolamento, esta enzima foi digerida por tripsina, e três de seus fragmentos trípticos foram sequenciados por espectrometria de massas, identificando-se essa enzima como sendo a CPA1, idêntica à pancreática. Em seguida, as CPA1 e CPA2 foram testadas para avaliar sua capacidade de processar angiotensinas, utilizando como substratos: Ang 1-12, Ang I, Ang 1-9 e Ang II. As duas CPAs isoladas foram capazes de hidrolisar a Ang I, sendo que, a CPA1 foi capaz de formar Ang 1-9, Ang II e Ang 1-7 por clivagens sequenciais, enquanto a CPA2 só foi capaz de formar Ang 1-9. A CPA1 foi capaz de processar a Ang II, enquanto a CPA2 não demonstrou essa capacidade. Quando o substrato ofertado foi a Ang 1- 12, a CPA2 foi capaz de processá-la de maneira mais eficiente que a CPA1. Para uma caracterização complementar, oito substratos sintéticos, com sequências baseadas em Ang 1-12, Ang I, Ang 1-9 e Ang II, foram sintetizados. Todos os oito substratos sintéticos demonstraram ser processados pelas CPA1 e CPA2, mas com especificidade diferente, mostrando que nem sempre a CPA1 hidrolisa preferencialmente aminoácidos alifáticos, e, a CPA2 os aromáticos. Neste trabalho também comparamos a expressão de ECA, ECA2, CPAs 1-6, CPB e CPN no mesentério, e, as atividades enzimáticas correspondentes nos perfusatos do LAM de rato e de camundongo. Demonstrou-se que o mesentério de ambos os animais expressam as carboxipeptidases CPA1, CPA2, CPA3, CPB, CPN, ECA e ECA2. As atividades enzimáticas atuantes sobre as angiotensinas encontradas nos perfusatos do LAM de rato e camundongo, também se mostraram semelhantes, sendo capazes de processar Ang 1-12, Ang I, Ang II e Bk. Portanto, concluímos com este trabalho, que o perfusato do LAM de rato contém as CPA1 e CPA2, idênticas às pancreáticas, cujas ações sobre os vasopeptídeos formaram peptídeos ativos como Ang 19, Ang II e Ang 1-7, constituintes do sistema reninaangiotensina. Além disso, mostrou-se que os camundongos, assim como os ratos, podem ser utilizados em estudos referentes às vasopeptidases do perfusato do LAM. 


\title{
Clínica Cirúrgica
}

\section{ANÁLISE MORFOLÓGICA POR IMUNOFLUORESCÊNCIA E DA EXPRESSÃO GÊNICA DE CASPASE 3 EM LINHAGENS DE ASTROCITOMA E GLIOBLASTOMA SBMETIDAS Á TERAPIA FOTODINÂMICA}

\author{
Marcelo Morguetti \\ Orientador: Prof. Dr. Luis Fernando Tirapelli \\ Tese de Doutorado apresentada em 18/01/2010
}

A terapia fotodinâmica (TFD) está atualmente estabelecida como uma modalidade amplamente aceita para o tratamento de uma grande variedade de tumores sólidos. Ela combina a luz, fotossensibilizador e oxigênio molecular, induzindo um efeito fototóxico sobre as células tratadas, em geral, através de danos oxidativos. Neste trabalho, estudamos o efeito da TFD usando Photogem ${ }^{\circledR}$, em cinco linhagens de células de glioma (U87, U138, U251, U343 e T98G). Os resultados mostraram que as células viáveis, avaliada pelo corante azul de tripan método de exclusão, diminuíram em duas linhagens celulares, U87 e U138, após o tratamento, mas não nas outras três. A apoptose, avaliada pelo nível de expressão de mRNA para caspase-3, esteve envolvida pelo menos em parte do mecanismo de morte das linhas celulares. Em conjunto, nossos resultados indicaram que a TFD com Photogem ${ }^{\circledR}$ pode atuar em qualquer avaliação de células de glioma incentivando novas pesquisas neste campo.

\section{ESTUDO DO ESTRESSE OXIDATIVO E ASPECTOS HISTOLÓGICOS TESTICULARES EM RATOS COM VARICOCELE}

Helena de Lima Chaves Castro

Orientador: Prof. Dr. Silvio Tucci Junior

Tese de Doutorado apresentada em 05/02/2010

A varicocele pode trazer sérias repercussões na espermatogênese e consequentemente na fertilidade. Objetivo: O objetivo deste estudo foi avaliar o estresse oxidativo e os aspectos histológicos testiculares e ultra-estruturais em ratos após a indução de varicocele e após o seu tratamento com a ligadura da veia espermática interna. Materiais e Métodos: Foram utilizados 49 ratos da raça Rattus norvegicus albinus, variedade Wistar, machos, com aproximadamente 45 dias de vida, os quais foram submetidos à indução de varicocele à esquerda por meio da estenose parcial da veia renal ipsilateral e seus testículos esquerdos foram estudados após seis semanas deste procedimento (grupos $\mathrm{V}=10, \mathrm{~S}=7$ e $\mathrm{C}=7$ ) e após seissemanas do tratamento cirúrgico da varicocele $(\mathrm{FV}=11, \mathrm{FS}=8$ e $\mathrm{FC}=6)$. O grupo $\mathrm{V}$ representa o grupo experimental, $\mathrm{S}$ o grupo sham e $\mathrm{C}$ o grupo controle. $\mathrm{O}$ grupo sham foi submetido apenas à laparotomia exploradora com inventário da cavidade abdominal. As biópsias testiculares foram destinadas à dosagem da concentração do malondialdeído (MDA) para avaliação do estresse oxidativo, ao estudo histológico e morfométrico e ao estudo ultraestrutural. Resultados: a concentração do MDA não diferiu nos diferentes grupos $(\mathrm{P}=0.9689)$. No grupo experimental $\mathrm{V}$, foram observadas alterações histológicas marcantes como: tortuosidade tubular (60\%), aumento do diâmetro da luz do túbulo seminífero (10\%), diminuição do diâmetro da luz do túbulo seminífero (10\%), aumento do espaço intertubular (60\%), espessamento da membrana basal (30\%), proeminência das células de Leydig (30\%) e alteração da linhagem germinativa (10\%). Em contrapartida, essas mesmas alterações tornaram-se menos significativas ou mesmo ausentes após a cirurgia corretiva da varicocele quando se observa o grupo FV, o qual apresentou apenas diminuição do diâmetro da luz do túbulo seminífero (10\%) e fibrose (36\%). No grupo $\mathrm{S}$ também foram observadas algumas alterações: aumento do espaço intertubular (14,3\%), diminuição da luz tubular (25\%) e 14,3\% proeminência das células de Leydig (14,3\%). Já no grupo FS apenas observou-se aumento do espaço intertubular (12,5\%). Para os três parâmetros morfometricamente avaliados: espaço intertubular (EI), luz intratubular (LI) e espessura da membrana basal (MB), o grupo $\mathrm{V}$ sempre apresentou as maiores médias, as quais foram significativas $(\mathrm{P}<0.001$, $\mathrm{P}<0.0001$ e $\mathrm{P}<0.0001$ ), respectivamente. Quando se comparou $\mathrm{V}$ aos outros grupos ( $\mathrm{S}, \mathrm{C}$ e FV) essa diferença também foi significativa $(\mathrm{P}<0.05)$. O grupo $\mathrm{S}$, para os parâmetros: EI e LI, quando comparado a $\mathrm{C}$ e FS, também diferiu significativamente $(\mathrm{P}<0.05)$. Alterações ultra-estruturais como: defeito na morfologia celular, nas junções intercelulares e no compartimento adluminal testicular, estiveram presentes nos grupos $\mathrm{V}$ e FV, sendo menos intensas nesses últimos e não observadas nos grupos S, C, FS e FC. Conclusões: não se observou diferença na concentração do malondialdeído (MDA) nos diversos grupos estudados. Alterações histológicas expressivas ligadas à infertilidade estiveram presentes no grupo experimental com varicocele e regrediram em sua maioria, após a varicocelectomia; o que se confirmou com a avaliação morfométrica de alguns parâmetros. Alterações ultra-estruturais também relacionadas à infertilidade estiveram presentes tanto no grupo experimental com varicocele quanto no grupo submetido à varicocelectomia, sendo mais suaves nesses últimos. 


\title{
ESTUDO DA AÇÃO DE NEUROTRANSMISSORES NA MOTILIDADE DO CÓLON DISTAL NORMAL E INFLAMADO. MODELO EXPERIMENTAL EM RATOS
}

\author{
Fábio Antonio Perecim Volpe \\ Orientadora: Profa. Dra. Yvone Avalloni de Morais Villela de Andrade Vicente \\ Tese de Doutorado apresentada em 19/02/2010
}

Introdução: As doenças funcionais do intestino resultam em alterações do hábito intestinal e podem ser secundários a processos inflamatórios com alterações motoras no cólon distal. No entanto, a atividade motora do cólon distal nesses casos não está de todo, caracterizada. Objetivo: O objetivo deste trabalho é propor um modelo experimental de estudo funcional do cólon distal, mediante análise da pressão intraluminal, em sistema fechado, em condições normais e após agressão visceral e, também, estudar a ação da L-aminoguanidina e epibatidine. Material e Método: 30 Ratos Wistar, com 250g, divididos em dois grupos I (normal) e II (inflamado) foram subdivididos em A e B, de acordo com a droga testada. Depois de anestesiados com uretana (1,2 g/kg, subcutânea), foi implantado um cateter intratecal (i.t.) no segmento meduar L6-S1 e realizado laparotomia para isolar cólon distal. A inflamação do cólon foi realizada mediante infusão de 3,0 ml de ácido acético a $0,2 \%$. Resultados: No grupo I, foram identificados os dois tipos de ondas, rítmicas e migratórias, na frequência de uma onda migratória para cada três a quatro rítmicas. A pressão basal foi de $71,6 \mathrm{cmH}_{2} \mathrm{O}$ em média. No grupo II observou-se aumento na frequência e grande variação na amplitude das contrações. A pressão basal foi de $48,5 \mathrm{cmH}_{2} \mathrm{O}$ em média. As pressões variaram entre os grupos I e II $(\mathrm{p}<0,05)$. Em seis animais, após a infusão de $2 \mu \mathrm{Mol}$ de L-aminoguanidina, o padrão das ondas de contração permaneceu preservado, porém houve aumento nas amplitudes. Nos dois grupos, a frequência das contrações do cólon distal foi menor quando comparada com o grupo o controle. Porém, foi observada maior prevalência de ondas do tipo migratória $(\mathrm{p}<0,05)$. A ação do epibatidine na motilidade do cólon distal foi estudada em seis animais tanto com cólon normal (grupo IB) como inflamado (grupo IIB). No grupo IB, após infusão i.t. de $0,3 \mu \mathrm{g}$ de epibatidine, observaram-se complexos de contrações periódicos, intercalados por períodos sem contrações efetivas. Após infusão i.t. de 1,0 $\mu \mathrm{g}$ de epibatidine, as contrações foram abolidas. Conclusões: O modelo experimental proposto demonstrou ser adequado para o estudo da motilidade do cólon distal e permitiu pesquisar a ação de neuro transmissores envolvidos na motilidade do cólon normal e inflamado. A ação da Laminoguanidina, na dose de $2 \mu \mathrm{Mol}$, via i.t. resulta no aumento da frequência e amplitude da onda de contração, no cólon distal tanto normal como inflamado. A ação de epibatidine via i.t., é dose dependente. A infusão de $0,3 \mu \mathrm{g}$ diminui a frequência das ondas de contração do cólon distal, tanto normal como inflamado. Na dose de 1,0 $\mu \mathrm{g}$ as contrações são inibidas, mostrando ausência de atividade motora no cólon distal, tanto normal como inflamado. Estudos posteriores são necessários para a análise da ação, de doses crescentes de epibatidine, na motilidade do cólon distal e das substâncias moduladoras da dor para melhor elucidar as alterações contraditórias encontradas, com esta droga, nas dosagens utilizadas neste trabalho.

\section{ESTUDO PROSPECTIVO DA HEMODINÂMICA VENOSA E DA QUALIDADE DE VIDA DE PACIENTES OPERADOS DE VARIZES DE MEMBROS INFERIORES}

\section{Rogério Takeyoshi Uema}

Orientador: Prof. Dr. Carlos Eli Piccinato

Tese de Doutorado apresentada em 26/02/2010

Introdução: As doenças funcionais do intestino resultam em alterações do hábito intestinal e podem ser secundários a processos inflamatórios com alterações motoras no cólon distal. No entanto, a atividade motora do cólon distal nesses casos não está de todo, caracterizada. Objetivo: O objetivo deste trabalho é propor um modelo experimental de estudo funcional do cólon distal, mediante análise da pressão intraluminal, em sistema fechado, em condições normais e após agressão visceral e, também, estudar a ação da L-aminoguanidina e epibatidine. Material e Método: 30 Ratos Wistar, com 250g, divididos em dois grupos I (normal) e II (inflamado) foram subdivididos em A e B, de acordo com a droga testada. Depois de anestesiados com uretana (1,2 g/kg, subcutânea), foi implantado um cateter intratecal (i.t.) no segmento meduar L6-S1 e realizado laparotomia para isolar cólon distal. A inflamação do cólon foi realizada mediante infusão de 3,0 ml de ácido acético a $0,2 \%$. Resultados: No grupo I, foram identificados os dois tipos de ondas, rítmicas e migratórias, na frequência de uma onda migratória para cada três a quatro rítmicas. A pressão basal foi de $71,6 \mathrm{cmH}_{2} \mathrm{O}$ em média. No grupo II observou-se aumento na frequência e grande variação na amplitude das contrações. A pressão basal foi de $48,5 \mathrm{cmH}_{2} \mathrm{O}$ em média. As pressões variaram entre os grupos I e II $(\mathrm{p}<0,05)$. Em seis animais, após a infusão de $2 \mu \mathrm{Mol}$ de L-aminoguanidina, o padrão das ondas de contração permaneceu preservado, porém houve aumento nas amplitudes. Nos dois grupos, a frequência das contrações do cólon distal foi menor quando comparada com o grupo o controle. Porém, foi observada maior prevalência de ondas do tipo migratória $(\mathrm{p}<0,05)$. A ação do epibatidine na motilidade do cólon distal foi 
estudada em seis animais tanto com cólon normal (grupo IB) como inflamado (grupo IIB). No grupo IB, após infusão i.t. de $0,3 \mu \mathrm{g}$ de epibatidine, observaram-se complexos de contrações periódicos, intercalados por períodos sem contrações efetivas. Após infusão i.t. de 1,0 $\mu \mathrm{g}$ de epibatidine, as contrações foram abolidas. Conclusões: O modelo experimental proposto demonstrou ser adequado para o estudo da motilidade do cólon distal e permitiu pesquisar a ação de neuro transmissores envolvidos na motilidade do cólon normal e inflamado. A ação da Laminoguanidina, na dose de $2 \mu \mathrm{Mol}$, via i.t. resulta no aumento da frequência e amplitude da onda de contração, no cólon distal tanto normal como inflamado. A ação de epibatidine via i.t., é dose dependente. A infusão de $0,3 \mu \mathrm{g}$ diminui a frequência das ondas de contração do cólon distal, tanto normal como inflamado. Na dose de 1,0 $\mu \mathrm{g}$ as contrações são inibidas, mostrando ausência de atividade motora no cólon distal, tanto normal como inflamado. Estudos posteriores são necessários para a análise da ação, de doses crescentes de epibatidine, na motilidade do cólon distal e das substâncias moduladoras da dor para melhor elucidar as alterações contraditórias encontradas, com esta droga, nas dosagens utilizadas neste trabalho.

\section{Clínica Médica}

\section{ANÁLISE DA OSCILAÇÃO POSTURAL ESTÁTICA MULTISSEGMENTAR EM JOVENS EUTRÓFICAS, IDOSAS EUTRÓFICAS E IDOSAS OBESAS}

José Ailton Oliveira Carneiro

Orientador: Prof. Dr. Eduardo Ferriolli

Dissertação de Mestrado apresentada em 10/02/2010

Existem evidências que o aumento da gordura corporal diminui a estabilidade postural e aumenta o risco de quedas em idosos, particularmente quando combinada com a baixa massa muscular. Objetivo: Avaliar e analisar a oscilação postural estática multissegmentar em jovens eutróficas, idosas eutróficas e idosas obesas em diferentes condições sensoriais usando um sistema de sensores eletromagnéticos tridimensional. Materiais e métodos: Participaram do estudo 46 mulheres, formando três grupos: 15 jovens eutróficas, 16 idosas eutróficas e 15 idosas obesas. Foi mensurado o peso corporal, a estatura, as circunferências da cintura e quadril, a força de preensão palmar e a composição corporal pelo método da água marcada com deutério. A posturografia foi realizada para avaliar oscilação postural utilizando o equipamento tridimensional Patriot (POLHEMUS®) com dois sensores. Estes sensores foram acoplados, nas voluntárias, no nível da primeira vértebra torácica (S1) e ao nível da região sacral (S2). Os testes foram realizados com as voluntárias em pé em uma postura confortável durante 60 segundos para o primeiro teste (avaliação do limite de estabilidade) e 90 segundos para os quatro últimos, realizados em quatro diferentes condições: 1) Olhos abertos, superfície estável (OASE); 2) Olhos fechados, superfície estável (OFSE); 3) Olhos abertos, superfície instável (OASI) e 4) Olhos fechados, superfície instável (OFSI). Foram registrados o limite de estabilidade, o deslocamento máximo ântero-posterior (a-p) e médio-lateral (m-l), a trajetória e a velocidade média (a-p), (m-l) e total. Os resultados obtidos foram comparados intra e intergrupos. Resultados: A idade, o peso e a estatura média foram $25,6 \pm 3,7$ anos, $54,4 \pm 6,5 \mathrm{~kg}$ e $161 \pm 0,03 \mathrm{~cm}$ para as jovens eutróficas; $68,3 \pm 2,7$ anos, $59,1 \pm 7,1 \mathrm{~kg}$ e $158 \pm 0,05 \mathrm{~cm}$ para as idosas eutróficas e $69,1 \pm 2,7$ anos, 79,1 $1 \pm 8,8 \mathrm{~kg}$ e $153 \pm 0,04 \mathrm{~cm}$ para as idosas obesas, respectivamente. Quanto às variáveis antropométricas, não foram observadas diferenças apenas na força muscular e massa muscular entre os grupos com $(\mathrm{p}=0,978)$ e $(\mathrm{p}=0,978)$, respectivamente. Nos parâmetros de oscilação postural intergrupos, foram encontradas diferenças significantes no deslocamento máximo, na condição OASE entre as jovens eutróficas e idosas obesas a-p S1 $(2,46 \pm 1,04 \mathrm{~cm}$ versus $1,46 \pm 0,63 \mathrm{~cm}$, respectivamente, $\mathrm{p}=0,02)$, OFSE entre as jovens eutróficas e as idosas obesas a-p $\mathrm{S} 1(2,67 \pm 1,24 \mathrm{~cm}$ versus $1,48 \pm 0,75 \mathrm{~cm}$, respectivamente, $\mathrm{p}=0,01)$ e entre as idosas eutróficas e idosas obesas a-p S2 (2,84 $\pm 1,27$ versus $1,83 \pm 0,50 \mathrm{~cm}$, respectivamente, $\mathrm{p}=0,01)$. Na superfície instável, as diferenças entre os grupos foram mais evidentes, sendo significantes em diversos parâmetros. Na análise intragrupo, observou-se que quanto menos informação sensorial as voluntárias obtinham, maior a sua velocidade e a trajetória total de oscilação. Quanto à flexibilidade do segmento corporal, foi observada diferença significante apenas entre as jovens eutróficas e idosas obesas na condição OASI $(\mathrm{p}=0,036)$. Conclusões: As idosas obesas apresentaram menor amplitude de movimento e menor limite de estabilidade em relação às jovens eutróficas e idosas eutróficas. A velocidade média total da oscilação postural não foi influenciada pelo aumento da gordura corporal. As idosas utilizaram mais o quadril do que as jovens para controlar o equilíbrio em quase todas as condições sensoriais. Quanto menos informações sensoriais as voluntárias utilizavam, maior era sua oscilação postural. 


\title{
AVALIAÇÃO DOS FATORES GENÉTICOS, CLÍNICOS E IMUNOLÓGICOS RELACIONADOS À INDEPENDÊNCIA DE INSULINA EXÓGENA PÓS-TRANSPLANTE DE CÉLULAS TRONCO HEMATOPOÉTICAS PARA DIABETES MELITO DO TIPO 1
}

\author{
Maria Carolina de Oliveira Rodrigues \\ Orientador: Prof. Dr. Júlio César Voltarelli \\ Tese de Doutorado apresentada em 18/02/2010
}

O transplante autólogo de células tronco hematopoéticas (TACTH) tem sido, recentemente, aplicado para o tratamento de diabetes melito do tipo 1 (DM1). Entretanto, apesar de seus resultados iniciais encorajadores, vários pacientes têm evoluído com recaídas. O presente estudo objetiva identificar fatores de risco que possam ter influenciado as recaídas. Também é objetivo deste estudo avaliar como o sistema imunológico se comporta durante as recaídas. Vinte pacientes com DM1, que haviam sido transplantados, foram avaliados retrospectivamente quanto às necessidades de insulina, e foram, então, divididos em dois grupos. No grupo 1 foram incluídos pacientes que deixaram de usar insulina após o transplante, por um período superior a 720 dias. O grupo 2, ao contrário, reuniu pacientes que ficaram livres de insulina após o TACTH, porém durante período menor do que 720 dias. Os grupos foram comparados entre si quanto a fatores demográficos, genéticos, ambientais, imunológicos e relacionados ao transplante. Alterações imunológicas durante as recaídas também foram avaliadas nos pacientes, com e sem uso de sitagliptina. Treze pacientes foram incluídos no grupo 1 e os sete restantes, no grupo 2. Os grupos diferiram em relação a dose de insulina em uso, peso corporal, níveis de hemoglobina glicada (HbA1c) e de peptídeo C. Não houve diferenças entre os grupos em relação aos seguintes dados da fase prétransplante: idade, raça, sexo, presença de haplótipos de alto risco para DM1, níveis de peptideo C, dose de insulina exógena, perda de peso antes do diagnóstico, tempo decorrido entre diagnóstico e mobilização ou entre diagnóstico e condicionamento, número de linfócitos totais e de suas subpopulações e níveis de expressão gênica de FOXP3. Os níveis de $\mathrm{HbA} 1 \mathrm{c}$ foram maiores no grupo 2 do que no grupo 1 , pré-transplante ( $\mathrm{p}=0,04)$. Infecções virais foram investigadas às recaídas, nos pacientes sintomáticos, através de exames de sangue e lavado nasal para detecção de vírus respiratórios, os quais resultaram negativos. Seis, das onze recaídas ocorreram durante a estação do inverno brasileiro ( $\mathrm{p}=0,01)$. A análise de reconstituição imunológica revelou que os linfócitos CD8+CD28- encontravam-se mais numerosos no grupo 1 (p=0,03). Finalmente, sitagliptina foi associada a aumento dos níveis de peptídeo C e de linfócitos CD4 reguladores (CD4+CD25high) e a suspensão da insulina, em dois pacientes que recaíram tardiamente após o transplante. Em conclusão, o presente estudo não identificou fatores de risco associados às recaídas, exceto pelos níveis de HbA1c pré-transplante. O grupo 1 , que teve melhor evolução pós-TACTH, apresentou maiores níveis de linfócitos CD8+CD28- (CD8Treg) após o transplante, indicando um perfil imunologicamente mais tolerante.

\section{Farmacologia}

\section{INTERAÇÃO ENTR E OS NEUROTRANSMISSORES ÓXIDO NÍTRICO E DOPAMINA NA MODULAÇÃO DO FILTRO SENSÓRIO-MOTOR}

\author{
Ana Carolina Castro Issy Pereira \\ Orientadora: Profa. Dra. Elaine Aparecida Del Bel \\ Tese de Doutorado apresentada em 29/01/2010
}

O filtro sensório-motor refere-se à habilidade de um evento sensorial em suprimir ou modificar uma resposta motora. A redução do reflexo de sobressalto (prepulse inhibition - PPI) pode ser considerada como uma medida operacional do filtro sensório-motor, processo através do qual o organismo filtra informações externas excessivas. Déficits cognitivos observados na esquizofrenia incluem deficiência no funcionamento do filtro sensório-motor, caracterizado por prejuízo no teste de PPI. Condição semelhante pode ser farmacologicamente induzida por agonistas dopaminérgicos ou inibidores do transportador de dopamina em humanos sadios e roedores. Esse efeito pode ser revertido por antipsicóticos típicos ou atípicos. Recentemente, modelos não farmacológicos de prejuízo no teste de PPI têm sido encorajados como possíveis modelos preditivos para a ação de antipsicóticos. O óxido nítrico (NO) modula os processos de liberação e recaptação de dopamina e é sugerido que esse neurotransmissor esteja envolvido em patologias relacionadas ao sistema dopaminérgico. O objetivo geral desse estudo foi investigar a habilidade dos inibidores da enzima de síntese do NO (NOS) em reverter o distúrbio no sistema de filtro sensório-motor avaliado por meio do teste de PPI. Foram utilizadas duas condições de 
prejuízo no teste de PPI para a investigação da interação entre o NO e a dopamina no sistema de filtro sensório-motor: (i) a indução farmacológica desse prejuízo induzida pelo psicoestimulante metilfenidato em camundongos Suíços e (ii) o prejuízo espontâneo no teste de PPI apresentado por ratos Wistar. Os presentes resultados revelaram que em camundongos o metilfenidato induz prejuízo dose-dependente no teste de PPI, efeito similar ao observado para a anfetamina. Os inibidores da NOS, 7NI e L-NOARG, reduziram o prejuízo induzido por metilfenidato no teste de PPI. A favor de que essa interação ocorra centralmente, o efeito do metilfenidato foi revertido pela aplicação de 7NI no ventrículo cerebral lateral. O ODQ, inibidor da guanilato ciclase solúvel, principal alvo de atuação do NO, apresentou efeito similar ao observado com os inibidores da NOS. Os resultados obtidos com o ODQ sugerem a participação da guanilato ciclase nos efeitos decorrentes da manipulação do sistema nitrérgico. Os antipsicóticos, típico e atípico, haloperidol e clozapina, reverteram o efeito do metilfenidato no teste de PPI, sugerindo que os efeitos do metilfenidato na reação de PPI sejam predominantemente dopaminérgicos. Adicionalmente, foi investigada a hipótese de que o tratamento com 7NI modificaria a expressão da proteína c-Fos induzida por metilfenidato em áreas envolvidas na modulação do filtro sensório-motor. O tratamento agudo com metilfenidato aumenta a expressão da proteína c-Fos no córtex cingulado, amígdala basolateral e núcleo central da amígdala no núcleo acumbens porção shell. Esse efeito é atenuado pelo pré-tratamento com 7 NI. Na segunda parte do trabalho foram utilizados ratos Wistar que apresentam prejuízo espontâneo no teste de PPI. O caráter preditivo deste modelo pôde ser confirmado pela reversão deste prejuízo pelos antipsicóticos, haloperidol e clozapina e ausência de efeito do diazepam. Efeitos similares foram obtidos com os inibidores da NOS, L-NOARG (tratamento agudo e subcrônico) e 7NI (tratamento agudo) que também reverteram o prejuízo espontâneo destes ratos no teste de PPI. O envolvimento do sistema dopaminérgico na condição de prejuízo espontâneo no teste de PPI é sugerido uma vez que essa condição foi modificada pela depleção dopaminérgica por meio de lesão unilateral no feixe prosencefálico medial com neurotoxina 6- hidroxidopamina (6-OHDA). Adicionalmente, foram observadas elevadas concentrações de monoaminas e seus metabólitos no estriado e no córtex pré-frontal dos animais Wistar com prejuízo espontâneo no teste de PPI, em comparação aos animais com desempenho normal. Em conjunto, nossos resultados corroboram a hipótese de interação entre os sistemas NO/GMPc e dopamina no controle do sistema de filtro sensório-motor e sugerem a participação de áreas límbicas nesta interação. Os presentes dados podem auxiliar a compreensão dos efeitos dos psicoestimulantes e no desenvolvimento de estratégias terapêuticas complementares para os distúrbios relacionados com a alteração do sistema dopaminérgico.

\section{ENVOLVIMENTO DOS RECEPTORES CXCR1/CXCR2 E DA CINC-1 NA RESPOSTA FEBRIL INDUZIDA PELO LPS}

\section{Lívia Harumi Yamashiro}

Orientadora: Profa. Dra. Glória Emília Petto de Souza

Dissertação de Mestrado apresentada em 04/02/2010

O primeiro relato da atividade pirogênica das quimiocinas foi feito por Davatellis et al., em 1989 através da injeção do dubleto MIP-1 em coelhos. Desde então, diferentes grupos de investigadores demonstraram a atividade pirogênica do MIP$1 \alpha$ e $\beta$, IL-8, RANTES e CINC-1. Para exercer sua função as quimiocinas ligam-se aos seus receptores presentes na superfície da célula-alvo. O presente estudo investigou a participação dos receptores CXCR1/CXCR2 na resposta febril induzida pela administração i.v. de LPS ( $5 \mu \mathrm{g} / \mathrm{kg})$, bem como seu envolvimento na resposta induzida pelos mediadores desencadeados por este estímulo. CINC-1, um agonista de receptores CXCR1 e CXCR2, injetado intracerebroventricular (i.c.v. 25 ng) ou intrahipotalamicamente (i.h. 50 pg) promoveu, de maneira dose-dependente, resposta febril e não hipertermia, pois o aumento de temperatura corporal foi acompanhado por uma diminuição na temperatura da pele da cauda. Investigamos também o efeito do antagonista destes receptores (reparixina) na febre induzida pelo LPS (300 ng, i.c.v.) e pela CINC-1 (150 ng, i.c.v.). A reparixina aboliu a febre induzida pelo agonista e reduziu a induzida pelo LPS. Além disso, $1 \mathrm{~h}$ após a administração do LPS a concentração da CINC-1 aumentou significativamente no fígado, hipotálamo, fluido cerebrospinal (CSF) e plasma sendo que os maiores aumentos ocorreram no fígado e no hipotálamo. A febre induzida pela ativação dos receptores CXCR1/ CXCR2 centrais, através da administração i.c.v. de CINC-1, mostrou ser dependente de prostaglandinas, pois no pico desta resposta $\left(4^{\mathrm{a}} \mathrm{h}\right)$ ocorreu aumento da concentração de $\mathrm{PGE}_{2}$ no CSF $\left(4^{\mathrm{a}} \mathrm{h}: \mathrm{aCSF}=45,0 \pm 25,4 \mathrm{pg} / \mathrm{ml} ; \mathrm{CINC}-1=2120,0 \pm 413,0\right.$ pg/ $\mathrm{ml}$ ). Apoiando este resultado, o tratamento dos animais com inibidores não seletivos para ciclooxigenases (COX), ibuprofeno (10mg/kg, i.p.) e indometacina (2 mg/kg, i.p.) ou com inibidor seletivo para COX-2, celecoxibe (5 mg/kg, p.o.) aboliu a febre e o aumento de $\mathrm{PGE}_{2}$ no hipotálamo. O bloqueio dos receptores CXCR1/CXCR2 não alterou a resposta febril induzida por IL-

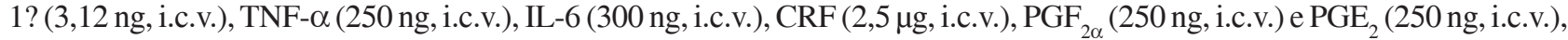
mediadores que sabidamente estão envolvidos na resposta febril induzida pelo LPS. Este conjunto de resultados indica que os receptores CXCR1/CXCR2 estão envolvidos na resposta febril induzida pelo LPS. Indica também que a CINC-1 é um dos mediadores envolvidos nesta resposta e em uma via dependente de $\mathrm{PGE}_{2}$, entretanto estes receptores não estão envolvidos na febre induzida pelas citocinas estudadas, pelo CRF ou pelas prostaglandinas $\mathrm{PGF}_{2 \alpha}$ e $\mathrm{PGE}_{2}$. 


\title{
PAPEL DA IL-17 NA GÊNESE DA HIPERNOCICEPÇÃO INFLAMATÓRIA EM MODELO DE ARTRITE INDUZIDA POR ANTÍGENO EM CAMUNDONGOS
}

\author{
Larissa Garcia Pinto \\ Orientador: Prof. Dr .Sérgio Henrique Ferreira \\ Dissertação de Mestrado apresentada em 10/02/2010
}

A interleucina 17 (IL-17) é uma citocina importante na fisiopatologia da artrite reumatóide (AR). No entanto, apesar de suas atividades pró-inflamatórias terem sido demonstradas, sua participação na gênese da nocicepção durante a AR não havia sido investigada. Neste trabalho, avaliamos o papel da IL-17 na gênese da nocicepção articular em um modelo de artrite induzida por antígeno (mBSA). Observamos que o desafio com mBSA na articulação fêmur-tibial de camundongos imunizados induziu uma hipernocicepção mecânica dose e tempo dependente. Além disso, a concentração local de IL17 estava aumentada 3 e $12 \mathrm{hs}$ após o desafio intra-articular com mBSA. Após, verificamos que o co-tratamento dos animais desafiados com um anticorpo contra IL-17 inibiu a hipernocicepão e o recrutamento de neutrófilos para a cavidade articular. Demonstramos que a injeção intra-articular de IL-17 foi capaz de induzir hipernocicepção e migração de neutrófilos, os quais foram reduzidos pelo pré-tratamento com fucoidina, um inibidor da adesão leucocitária. O efeito hipernociceptivo da IL-17 foi também reduzido em camundongos deficientes para o receptor do tipo I do TNF- $\alpha$ e pelo prétratamento com infliximabe (anticorpo anti-TNF), por um antagonista dos receptores CXCR1/2 (DF-2156) e pelo antagonista do receptor da IL-1 (IL-1ra). Corroborando com estes achados, observamos que a injeção de IL-17 na articulação aumentou a produção de TNF- $\alpha$, IL-1 $\beta$ e CXCL1/KC. Além disso, o tratamento com doxiciclina (inibidor inespecífico de metaloproteinases, MMPs), bosentan (antagonista dos receptores de endotelina $\mathrm{ET}_{\mathrm{A}} / \mathrm{ET}_{\mathrm{B}}$ ), indometacina (inibidor de COX) ou guanetidina (bloqueador simpatico) inibiram a hipernocicepção induzida pela IL-17. A injeção de IL-17 na articulação também aumentou a produção de PGE $_{2}$, a atividade de MMP-9 e a expressão de RNAm na membrana sinovial de MMP-9, COX-2 e PPET-1. Estes resultados sugerem que a IL-17 é uma citocina pró-nociceptiva na artrite induzida por mBSA e seu efeito é dependente da migração de neutrófilos e de vários mediadores pró-inflamatórios, como TNF- $\alpha$, IL-1 $\beta$ , quimiocina CXCL1/KC, MMPs, endotelinas, prostaglandinas e aminas simpáticas. Deste modo, podemos propor a IL-17 como um alvo terapêutico para o controle dos sintomas da AR.

\section{FALÊNCIA DE MIGRAÇÃO DE NEUTRÓFILOS NA SEPSE GRAVE INDUZIDA POR PNEUNOMIA: PAPEL DA ENZIMA HEME OXIGENASE}

\author{
Paula Giselle Czaikoski \\ Orientador: Prof. Dr .Fernando de Queiróz Cunha \\ Dissertação de Mestrado apresentada em 22/02/2010
}

Sepse grave é considerada a causa mais comum de morte em Unidades de Terapia Intensiva, sendo as infecções pulmonares responsáveis por $45,3 \%$ dos casos. Diversos estudos demonstram que, durante a sepse grave induzida por peritonite, ocorre falência da migração de neutrófilos para o foco infeccioso, havendo correlação positiva entre esse fenômeno e o aumento dos níveis séricos de citocinas, bacteremia e aumento da mortalidade dos animais. Entretanto, não existem relatos na literatura de falência de migração de neutrófilos para os espaços broncoalveolares em pneumonias. Desta forma, padronizamos um modelo de sepse induzida por pneumonia por Klebsiella pneumoniae em camundongos C57BL/6. Neste modelo foi induzida sepse não grave e grave através da administração intratraqueal de $1 \times 10^{7}$ e $4 \mathrm{X} 10^{8} \mathrm{UFC} /$ camundongo, respectivamente. Camundongos com sepse não-grave apresentaram eficiente migração de neutrófilos para o pulmão com consequente controle local da infecção e alta taxa de sobrevida. No entanto, camundongos com sepse grave apresentaram falência de migração de neutrófilos para os alvéolos pulmonares, intensa bacteremia e alta taxa de mortalidade. Este estudo também investigou a participação da heme oxigenase $(\mathrm{HO})$ e seus metabólitos na falência de migração de neutrófilos ao pulmão. A inibição da enzima HO restabeleceu parcialmente a migração de neutrófilos para o pulmão, diminuiu a bacteremia e aumentou a taxa de sobrevida em torno de $20 \%$ nos camundongos com sepse grave. Além disso, a inibição da heme oxigenase melhorou a função pulmonar dos animais com sepse grave. Observamos também que a biliverdina, produto da degradação do heme pela HO, inibiu a migração de neutrófilos nos animais com sepse não-grave e o monóxido de carbono (CO), outro produto, não induziu esse efeito. Esses dados sugerem que a via HO-biliverdina participa da falência de migração de neutrófilos e, consequentemente, no desenvolvimento da resposta inflamatória sistêmica na sepse induzida por pneumonia. 


\title{
PAPEL DA ENZIMA HEME OXIGENASE-1 NA PATOGÊNESE DA SEPSE GRAVE
}

\section{Andressa de Freitas}

Orientador: Prof. Dr. Fernando de Queiróz Cunha

Tese de Doutorado apresentada em 25/02/2010

O termo sepse é definido como síndrome da resposta inflamatória sistêmica (SRIS), decorrente de uma infecção, geralmente de origem bacteriana. Durante a sepse grave induzida por diferentes modelos experimentais é observado falência da migração de neutrófilos para o foco infeccioso, a qual está associada com a disseminação da infecção e, consequente mortalidade. Nossos resultados prévios demonstram que os produtos da enzima heme oxigenase (HO), monóxido de carbono (CO) e biliverdina, inibem o recrutamento de neutrófilos na vigência de um processo inflamatório induzido por carragenina. Por outro lado, estudos demonstram que altas concentrações de heme livre na circulação têm atividade pró-inflamatória e também podem catalisar a geração de radicais livres. No presente trabalho foi demonstrado que a inibição da HO-1 no início do processo infeccioso, através do pré-tratamento dos animais sépticos com ZnPP IX (inibidor específico da HO-1) preveniu a redução da expressão do receptor quimiotáxico CXCR2 na superfície dos neutrófilos circulantes. Esse evento tornou os neutrófilos capazes de responder a agentes quimiotáxicos, como o MIP-2 e, desta forma, essas células migraram para o foco da infecção. Assim, os animais apresentaram significante redução na quantidade de bactérias no lavado peritoneal e no sangue, diminuição das concentrações de TNF- $\alpha$ circulantes, decréscimo do infiltrado de neutrófilos no pulmão, menor lesão hepática, cardíaca, renal e aumento da pressão arterial média, resultando no aumento da sobrevida dos animais. Por outro lado, o tratamento com ZnPP IX, 30 minutos antes da cirurgia e 6 horas após a indução da sepse não preveniu a redução da expressão do receptor CXCR2 na superfície dos neutrófilos e, estes animais, diferentemente dos pré-tratados com ZnPP IX, apresentaram falência do recrutamento de neutrófilos para a cavidade peritoneal e consequente mortalidade. Também observamos que estes animais apresentaram aumento da quantidade de bactérias no lavado peritoneal e no sangue, concentrações séricas extremamente elevadas de TNF- $\alpha$, intenso infiltrado de neutrófilos no pulmão, lesão hepática, cardíaca e disfunção renal. Diante dos dados obtidos com o prétratamento seguido de pós-tratamento com ZnPP IX,sugerimos que o aumento da mortalidade obtido com este protocolo deve-se ao aumento das concentrações de heme. Consistente com essa possibilidade demonstramos que, os animais submetidos ao pré-tratamento seguido de pós-tratamento com ZnPP IX apresentaram aumento do heme plasmático. Ademais, o tratamento dos animais com alta dose de hemin promoveu resultados similares àqueles observados com o prétratamento seguido de pós-tratamento com ZnPP IX. Verificamos também que há um efeito direto do hemin sobre os neutrófilos, uma vez que a incubação in vitro de neutrófilos isolados da medula óssea com o hemin promoveu redução da quimiotaxia induzida por MIP-2, de maneira concentração-dependente e redução da expressão do receptor CXCR2. Concluindo, os resultados do presente estudo demonstram um papel dual da via HO-1 durante a sepse grave. Por um lado, a inibição da HO-1 no início do processo infeccioso previne a falência da migração de neutrófilos, resultando em um controle do quadro infeccioso e, consequente aumento da sobrevida dos animais. Por outro lado, a inibição contínua da HO-1 durante a sepse grave, promove aumento das concentrações plasmáticas de heme, o qual está envolvido com a falência da falência da migração de neutrófilos para o foco da infecção e consequente mortalidade. Desse modo, o nosso estudo colabora de forma significativa para a melhor compreensão dos mecanismos fisiopatológicos envolvidos na sepse grave.

\section{Fisiologia}

\section{PAPEL DO SISTEMA NERVOSO SIMPÁTICO NO CONTROLE DAS VIAS DE GERAÇÃO DE GLICEROL-3-FOSFATO NO TECIDO ADIPOSO EPIDIDIMAL DE RATOS}

\author{
Danúbia Frasson \\ Orientadores: Profs. Drs. Isis do Carmo Kettelhut \\ Tese de Doutorado apresentada em 27/01/2010
}

O objetivo do presente trabalho foi verificar os efeitos do sistema nervoso simpático no tecido adiposo branco epididimal (EPI) nas três vias de geração de glicerol-3-fosfato (G3P): a) a partir da via glicolítica, estimada pela captação de glicose; b) a partir da gliceroneogênese, avaliada pela velocidade de incorporação de 1-[14C]-piruvato em glicerol de 
triacilglicerol (TAG) e pela atividade da fosfoenolpiruvato carboxiquinase (PEPCK); c) a partir da fosforilação direta do glicerol, avaliada pela atividade da gliceroquinase (GyK). Os experimentos foram realizados no EPI de ratos nas seguintes situações experimentais: jejum de 48 horas, diabetes mellitus, adaptados a uma dieta hiperprotéica, livre de carboidratos (HP) e adaptados a dieta hipercalórica, hiperlipídica do tipo cafeteria (HCHL). Foram utilizados animais alimentados com uma dieta comercial padrão de biotério como controle dos grupos estudados, com exceção do grupo HP, cujos controles foram alimentados com uma dieta purificada balanceada. O peso do EPI mostrou-se reduzido no jejum de 48horas, no diabetes e nos animais que receberam a dieta HP em relação aos seus controles. A desnervação promoveu uma menor redução no peso do EPI nos grupos diabéticos e HP quando comparado aos tecidos inervados. A desnervação no jejum impediu a redução do peso do tecido, o qual se manteve semelhante ao peso dos tecidos dos animais alimentados. A dieta HCHL aumentou o peso do EPI e a desnervação não alterou este parâmetro. O índice de captação de glicose in vivo e in vitro foi menor nos animais jejuados, diabéticos e alimentados com a dieta HP em relação aos seus controles. A desnervação não alterou este parâmetro nos animais jejuados e alimentados com a dieta HP, porém causou uma redução adicional na captação da hexose nos animais diabéticos. A dieta HCHL aumentou este parâmetro e a desnervação simpática não alterou a captação de glicose no tecido dos animais HCHL. A incorporação de 1-[14C]-piruvato em glicerol-TAG e a atividade da PEPCK mostraram-se aumentada no EPI dos animais jejuados, diabéticos e alimentados com a dieta HP. A desnervação diminuiu estes parâmetros nos animais jejuados e diabéticos. Embora reduzida, esta via se manteve predominante na geração de G3P nestas situações. Nos animais HP, a pequena redução da atividade da PEPCK com a desnervação, não comprometeu a estimulada incorporação de piruvato em glicerol-TAG. A dieta HCHL reduziu a incorporação de 1-[14C]piruvato em glicerol- TAG e a atividade da PEPCK. A desnervação causou uma redução adicional nestes parâmetros no EPI dos animais HCHL. A atividade da GyK foi reduzida no jejum e na dieta HP, não foi alterada no estado diabético, mas foi aumentada pela dieta HCHL. A desnervação reduziu a atividade da enzima em todos os grupos experimentais. Os dados deste trabalho corroboram a hipótese que existe um controle recíproco entre as vias de geração de G3P, principalmente entre a via glicolítica e a gliceroneogênese, independente da atividade da gliceroquinase. A formação de G3P no TAB epididimal a partir da: a) via glicolítica é estimulada pela insulina. A ação estimulatória do SNS se torna evidente apenas em situações de deficiência insulínica, como no diabetes; b) via gliceroneogênica é inibida pela insulina e ativada pelo SNS; c) via de fosforilação direta do glicerol $(\mathrm{GyK})$ parece depender principalmente da inervação simpática no tecido adiposo, além de fatores hormonais e/ou metabólicos. Desta forma, podemos sugerir que existe uma interação entre a atividade do SNS e os níveis de insulina no controle das vias de geração de G3P no EPI de ratos, entretanto não podemos excluir a possibilidade de outros fatores hormonais e/ou metabólicos também interferirem nestes processos.

\title{
ESTUDO DO PALADAR A DIFERENTES AMINOÁCIDOS NO RATO NORMAL E NO RATO COM DESNUTRIÇÃO
}

\author{
Allan Fernando de Paula \\ Orientador: Prof. Dr. Ricardo Brandt de Oliveira \\ Dissertação de Mestrado apresentada em 01/02/2010
}

Introdução: existe evidencia de que o sabor umami detecta os alimentos ricos em proteínas e aminoácidos, o que presumivelmente interfere na ingestão destes alimentos. Há experimentos publicados que relacionam quadros de desnutrição ou alimentação deficiente de determinados aminoácidos, com o consumo voluntário de soluções ou ração contendo tais aminoácidos.

Objetivos: os objetivos deste trabalho foram: a caracterização das preferências gustativas para diferentes aminoácidos no rato normal e o efeito da desnutrição protéica sobre essas preferências.

Metodologia: o estudo compreendeu duas fases distintas: na primeira foram feitas comparações de consumo de soluções de aminoácidos isolados (10 gramas por litro de água) em um período curto (5 dias). As comparações foram realizadas em 4 grupos distintos, e cada grupo foi composto de 20 animais: 10 controles e 10 desnutridos. A desnutrição foi induzida pelo oferecimento de ração hipoprotéica ( $5 \%$ de caseína na primeira fase e 7,5\% de caseína na segunda fase). As soluções de aminoácidos comparadas em cada grupo foram: glutamato e glicina, glutamato e valina, triptofano e glicina e triptofano e valina, todas na concentração de $10 \mathrm{~g} / \mathrm{L}$. Na segunda fase foram realizadas comparações de consumo de soluções contendo glutamato mais um aminoácido não essencial (glicina) e glutamato mais um aminoácido essencial (lisina ou triptofano) por um período de 42 dias. Esta segunda fase foi composta de 3 grupos de animais, sendo um formado por 10 animais controles e 10 desnutridos que não receberam soluções, outro grupo com a mesma divisão de animais, mas que receberam soluções de glutamato mais glicina e glutamato mais lisina, e o último grupo recebeu soluções de glutamato mais glicina e glutamato mais triptofano. 
Resultados, discussão e conclusão: observou-se, tanto na fase 1 como na fase 2, que: a glicina e o glutamato em solução são muito atrativos; a de lisina é atrativa mas em menor intensidade do que as anteriores; a de valina é pouco atraente; o consumo da solução de triptofano foi tão pequena que esta é possivelmente aversiva. Os resultados da fase 1 indicaram que o consumo de soluções de glutamato e de valina de animais desnutridos foi significativamente maior do que o de animais controles. Entretanto, no subgrupo de ratos desnutridos, o consumo da solução de glutamato correlacionouse positivamente com o peso do animal. Na fase 2 os animais desnutridos, nas duas últimas semanas experimentais, mas não nas anteriores, apresentaram consumo significativamente maior de lisina e triptofano; a comparação do consumo de solução de glicina foi impossibilitada pelo consumo excessivo e esgotamento dos frascos. Também se constatou que os animais da segunda fase apresentaram esteatose hepática. Entre os desnutridos, o consumo de solução de lisina foi inversamente correlacionado com o peso corporal.

\title{
MECANISMOS OPIOIDÉRGICOS ENVOLVIDOS NA ANTINOCICEPÇÃO INDUZIDA COMPORTAMENTALMENTE E POR ESTIMULAÇÃO MESENCEFÁLICA NO TELEÓSTEO Leporinus macrocephalus
}

\author{
Fabiana Luca Alves
}

Orientadora: Profa. Dra. Anette Hoffmann

Tese de Doutorado apresentada em 11/02/2010

A habilidade dos peixes em perceber a dor é um assunto controverso. Alguns autores argumentam que a dor resulta da ativação de várias regiões do córtex cerebral, restringindo assim a sua percepção aos humanos e primatas. No entanto, recentes pesquisadores têm demonstrado que existem algumas semelhanças entre os peixes e os vertebrados superiores em relação à estrutura básica do sistema nervoso envolvida na percepção dolorosa. O objetivo deste estudo foi examinar as respostas do piauçu evocadas pela injeção subcutânea de formalina a 3\% (teste algesimétrico muito empregado em mamíferos), pesquisar a existência de um sistema analgésico endógeno e sua ativação comportamental, bem como estudar a participação do teto óptico, como possível componente desse sistema. As alterações dos batimentos operculares e da atividade natatória foram utilizadas como indicadores nociceptivos. Nossos dados demonstraram que a injeção subcutânea de formalina a 3\% na região próxima à nadadeira adiposa induziu um aumento dos batimentos operculares, o qual foi bloqueado pela injeção sistêmica de morfina (agonista opióide) nas doses de $50 \mathrm{mg} / \mathrm{kg}, 100 \mathrm{mg} / \mathrm{kg}$, mas não de 30mg/kg. A injeção prévia sistêmica de morfina $50 \mathrm{mg} / \mathrm{kg}$ também bloqueou o aumento da atividade natatória. O pré-tratamento com naloxona (antagonista opióide) nas doses de $10 \mathrm{mg} / \mathrm{kg}$ e $20 \mathrm{mg} / \mathrm{kg}$ não foram suficientes para reverter o efeito da morfina, porém o bloqueio da resposta foi obtido com a dose de $30 \mathrm{mg} / \mathrm{kg}$. Essas respostas neurovegetativas e comportamentais demonstraram que os peixes não reagem passiva e reflexamente a um potente estímulo doloroso, mostrando uma possível capacidade de experimentar a dor. No entanto, os animais não responderam à injeção subcutânea de capsaicina, que é um dos componentes vanilóides ativos da pimenta e pode evocar uma sensação de formigamento e ardor e atua ativando canais de cátions não seletivos, chamados de VR-1, nas terminações nervosas de fibras amielínicas do tipo C. Além disso, o aumento da atividade natatória decorrente de injeção subcutânea de formalina a 3\% foi bloqueado (ou reduzido) após a exposição dos animais à substância de alarme de um co-específico, mostrando que o sistema analgésico endógeno pode ser mobilizado em situações que potencialmente sinalizam predação. Esse efeito é bloqueado pela naloxona (20mg/kg) mostrando sua natureza opióide. Assim, podemos sugerir que a antinocicepção permite que um animal ameaçado, em uma situação de perigo iminente, apresente comportamentos de defesa (freezing) prevenindo que os comportamentos recuperativos interfiram nos esforços defensivos, aumentando a sua chance de sobrevivência. Observamos também que a microinjeção central de morfina $1,1 \mathrm{nmol} / 0,1$ ? 1 no teto óptico medial, reduz a atividade natatória induzida pela injeção subcutânea de formalina a 3\%. Nos vertebrados não-mamíferos o teto óptico é uma estrutura homóloga ao colículo superior, que sabidamente está envolvido em defesa e antinocicepção. Dessa forma, parece razoável que o teto óptico esteja envolvido com respostas defensivas e de antinocicepção, bem como de orientação e aproximação frente ao estímulo novo, pois a decisão de se orientar frente a esse estímulo está intimamente ligada com a decisão de evitá-lo. Caso a decisão escolhida seja evitar tal estímulo é necessário que as respostas antinociceptivas sejam deflagradas juntamente com comportamentos defensivos, já que durante um confronto presa-predador é importante amenizar a sensação aversiva. 


\title{
ALTERAÇÕES NO ACOPLAMENTO ENTRE AS ATIVIDADES SIMPÁTICA E RESPIRATÓRIA EM RATOS JOVENS SUBMETIDOS À HIPÓXIA CRÔNICA INTERMITENTE
}

\author{
Daniel Breseghello Zoccal \\ Orientador: Prof. Dr. Benedito Honorio Machado \\ Tese de Doutorado apresentada em 26/02/2010
}

No presente trabalho estudamos as alterações cardiovasculares e respiratórias promovidas pela hipóxia crônica intermitente (HCI) em ratos, bem como os possíveis mecanismos centrais envolvidos nessas alterações. Para tanto, utilizamos ratos Wistar jovens submetidos à $\mathrm{HCI}(6 \%$ de $\mathrm{O} 2$ por 30 a $40 \mathrm{seg}$, a cada 9 minutos, 8 horas por dia) por 10 dias, enquanto ratos controle foram mantidos em condições de normóxia (20,8\% de O2) durante o mesmo período. Observamos que ratos jovens submetidos à HCI por 10 dias apresentaram um aumento da pressão arterial basal associado a uma hiperatividade simpática basal, a qual foi avaliada por meio do bloqueio ganglionar e pela análise espectral. Esse aumento da atividade simpática após a HCI não estava relacionado a reduções no controle barorreflexo da freqüência cardíaca. Por outro lado, os níveis elevados da pressão arterial de ratos HCI apresentaram uma maior variabilidade associada à respiração, indicando uma maior influência da atividade respiratória sobre o sistema cardiovascular após a HCI. Coerente com esses resultados preparações in situ (preparação coração-tronco cerebral isolados) de ratos HCI apresentaram níveis elevados da atividade simpática torácica, observados durante a fase final da expiração, os quais se correlacionaram com uma hiperatividade motora abdominal durante a mesma fase respiratória, indicando que os mecanismos neurais envolvidos com o acoplamento entre as atividades simpática e respiratória estão alterados após a HCI. Associado as alterações basais, verificamos que preparações in situ de ratos HCI apresentaram respostas simpato-excitatória e taquipnêica à ativação do quimiorreflexo de maior magnitude, sugerindo não somente uma facilitação do processamento das respostas do quimiorreflexo, mas também que as alterações autonômicas promovidas pela HCI estão associadas às alterações respiratórias. Em preparações in situ, verificamos que microinjeções de ATP na superfície rostral ventrolateral do bulbo (RVL) de ratos HCI promoveram respostas simpatoexcitatórias de maior magnitude, sem alterações na magnitude das respostas de redução da freqüência de despolarização do nervo frênico e de aumento da atividade motora abdominal. Esse maior aumento da atividade simpática promovido pelas microinjeções de ATP no RVL de ratos HCI se correlacionou com um aumento da densidade dos receptores P2X3 e P2X4 do ATP nesta região, a qual foi avaliada pela técnica de western blot. Além disso, verificamos que microinjeções de L-glutamato no aspecto caudal do núcleo do trato solitário (NTSc) de ratos HCI promoveram menores respostas de excitação pós-inspiratória vagal e apnéia, associadas a respostas simpatoexcitatórias de maior magnitude. Observamos também alterações no padrão respiratório basal promovidas pelo antagonismo simultâneo dos receptores ionotrópicos do L-glutamato e dos receptores P2 do ATP no NTSc de ratos HCI foi menos expressivo do que nos ratos controle. Esses resultados estão de acordo com as observações de que a densidade da subunidade NMDA R1 dos receptores glutamatérgicos está aumentada no NTSc de ratos HCI. Esse conjunto de resultados indicam que a HCI parece interferir com os mecanismos purinérgicos e glutamatérgicos no RVL e no NTSc, respectivamente, os quais podem contribuir para as alterações no acoplamento central entre as atividades simpática e respiratória observadas em ratos jovens submetidos à HCI.

\section{PARTICIPAÇÃO DO ESTRADIOL NA SECREÇÃO HORMONAL E ATIVAÇÃO NEURONAL INDUZIDAS POR ALTERAÇÕES DE VOLUME E OSMOLALIDADE DO LÍQUIDO EXTRACELULAR}

\author{
Tatiane Vilhena Franco \\ Orientador: Prof. Dr. José Antunes Rodrigues \\ Dissertação de Mestrado apresentada em 26/03/2010
}

A homeostase hidreletrolítica é essencial para a sobrevivência do organismo animal. O volume e a osmolalidade dos fluidos corporais são mantidos constantes por complexos mecanismos neuroendócrinos, autonômicos, hemodinâmicos, renais e comportamentais. Um modelo experimental extensivamente usado capaz de induzir essas respostas é a expansão do volume extracelular (EVEC). Entre os vários fatores que são ativados pela EVEC, a secreção de vasopressina (AVP), ocitocina (OT) e peptídeo natriurético atrial (ANP) é um importante evento neuroendócrino que participa dessas respostas homeostáticas. A AVP e a OT são sintetizadas e secretadas por neurônios magnocelulares localizados nos núcleos paraventricular (NPV) e supra-óptico (NSO) do hipotálamo. Esses hormônios juntamente com o ANP estão envolvidos nas respostas renais a alterações do volume ou osmolalidade do líquido extracelular. Estudos anteriores realizados em machos têm demonstrado que tanto a EVEC isotônica quanto hipertônica induzem distensão atrial, a qual aumenta a liberação de ANP o que, por meio de um reflexo neuroendócrino, eleva também a secreção de OT. No que diz respeito à secreção de AVP, 
esta se reduz frente à EVEC isotônica, sendo o principal estímulo para a sua liberação a elevação da osmolalidade plasmática. Diferentes estudos têm demonstrado que os hormônios esteróides gonadais, em particular, o estradiol, tem ação relacionada ao equilíbrio hidreletrolítico, modulando, dentre outros mecanismos, a secreção de AVP, OT e ANP. Diante desse contexto, o presente trabalho visou avaliar a participação do estradiol na resposta hormonal e na ativação dos neurônios magnocelulares do NPV e NSO em resposta a alterações de volume e osmolalidade plasmática induzidas pela EVEC. Os resultados apresentados mostram que a EVEC, tanto isotônica ( $\mathrm{NaCl}$ 0,9\% 2ml/100g p.c., e.v.) quanto hipertônica ( $\mathrm{NaCl}$ 1,8\%, 2ml/100g p.c., e.v.), induziu um aumento na concentração plasmática de OT e ANP, porém não alterou a secreção de AVP em animais que receberam somente veículo (óleo de milho, 0,1 ml/rata). O prétratamento com estradiol (10ìg/Kg s.c.) não modificou a secreção hormonal induzida pela EVEC isotônica. Entretanto, em resposta à EVEC hipertônica, a reposição com estradiol aumentou a concentração plasmática de AVP e potencializou a secreção de OT e ANP. Com relação à ativação neuronal, foi observado que somente a EVEC hipertônica induziu alterações significativas no número de neurônios duplamente marcados c-Fos-OT e c-Fos-AVP no NPV e NSO. O pré-tratamento com estradiol não induziu modificações na ativação neuronal em resposta à EVEC isotônica, porém em resposta à EVEC hipertônica, potencializou o número de neurônios ocitocinérgicos e vasopressinérgicos ativados na porção medial magnocelular do NPV (PaMM) e também no NSO. Em conjunto, os resultados sugerem que as ações do estradiol estejam relacionadas ao estímulo osmótico, pois a secreção de AVP, OT e ANP, assim como a ativação neuronal vasopressinérgica e ocitocinérgica, foram influenciadas pelo estradiol em resposta à EVEC hipertônica e, ao contrário disso, essas respostas não foram observadas como resultado de alteração isosmótica do volume plasmático.

\section{Genética}

\section{PADRÃO DE INATIVAÇÃO DO CROMOSSOMO X E EXPRESSÃO DE MICRORNAS X-ESPECÍFICO NA PRÉ-ECLÂMPSIA}

\section{Adriane Araujo de Oliveira}

Orientador: Prof. Dr. Ester Silveira Ramos

Tese de Doutorado apresentada em 27/01/2010

As síndromes hipertensivas gestacionais estão entre as maiores causas de morte materna e fetal. Entre elas destacase a pré-eclâmpsia (PE), que caracteriza-se pelo aumento da pressão arterial e proteinúria, a partir da $20^{a}$ semana de gestação. Embora sua etiologia seja ainda discutida, o papel dos fatores genéticos é amplamente aceito. Alterações do padrão da inativação do cromossomo $\mathrm{X}$, processo epigenético encontrado em mamíferos com placenta, têm sido encontradas em algumas doenças que ocorrem exclusivamente em mulheres. O XIST é um gene chave nesse processo. Por outro lado, muitos microRNAs (pequenos RNAs não codificantes) são expressos abundantemente na placenta humana e alguns estão mapeados no cromossomo X. O objetivo do presente trabalho foi a verificação do padrão de inativação do cromossomo X e da expressão dos genes XIST e dos microRNAs X-específicos miR-221, miR-222 e mir-223 em mulheres com PE. O ensaio de HUMARA (receptor de andrógeno humano) utilizando PCR convencional e digestão com a enzima sensível à metilação HpaII foi analisado de forma qualitativa (visualização em gel de poliacrilamida) e semi-quantitativa (sequenciamento), sendo realizado a partir de sangue periférico (todas as amostras) e de tecido placentário [apenas das placentas de fetos femininos (17 amostras)]. Para o estudo do padrão de expressão foi obtido cDNA por transcrição reversa, a partir de RNA total extraído do tecido placentário (30 amostras). A análise foi realizada por meio de PCR em tempo real. Foram utilizados os testes de Quiquadrado e de t-Student, além do modelo linear generalizado para a análise estatística. Não houve diferença estatisticamente significativa para o parâmetro de inativação do cromossomo X entre os grupos controle e de PE, independente do tipo de tecido estudado (sangue ou placenta) quando foram aplicados os ensaios de HUMARA qualitativo e semi-quantitativo. Para o gene XIST e o microRNA miR-221 não foi evidenciada diferença estatisticamente significativa entre os grupos controle e de PE. O microRNA mir-223 não apresentou transcritos detectáveis em nenhum dos grupos de estudo. Para o microRNA $m i R-222$, houve diferença estatisticamente significativa, sendo que no grupo de PE a expressão foi mais elevada. Não foi encontrada associação entre o padrão de inativação do cromossomo X e a expressão do gene XIST e dos microRNAs estudados. Embora a inativação preferencial do cromossomo $\mathrm{X}$ tenha sido encontrada nos dois grupos, padrões de inativação preferencial extrema foram verificados em um número maior de casos com PE. Os resultados mostram que o miR-222 apresenta potencial para ser utilizado como marcador molecular da PE, sugerindo também que exista uma diminuição na expressão de seus genes-alvo que devem ser estudados como candidatos na patogênese da doença. 


\title{
ANÁLISE DA EXPRESSÃO DA REGIÃO MHM E DE GENES CANDIDATOS A SEXO-DETERMINANTES EM DIFERENTES ESTADIOS DO DESENVOLVIMENTO DE GALLUS GALLUS
}

\author{
Lisandra Cristina Caetano da Silva
}

Orientadora: Profa. Dra. Ester Silveira Ramos

Tese de Doutorado apresentada em 28/01/2010

Os embriões de galinha (Gallus gallus) são há muito tempo considerados um importante modelo de estudo para a biologia do desenvolvimento, especialmente devido a acessibilidade dos mesmos durante o desenvolvimento embrionário. Entretanto, apesar do conhecimento do sistema cromossômico de determinação sexual (ZZ para machos e ZW para fêmeas), não se sabe ao certo quais genes são responsáveis pela determinação e diferenciação sexuais em Aves. Também há muita controvérsia com relação à existência ou não de mecanismos de compensação de dose em Aves: enquanto algumas evidências apontam para o efeito da dosagem do cromossomo $\mathrm{Z}$, outros dados indicam que pode haver um efeito fêmeo-determinante gerado por um gene do cromossomo W. Genes relacionados à determinação e diferenciação sexuais em vertebrados, bem como sequências específicas de Aves, foram analisados em gônadas, tecido cardíaco e mesonéfrico de embriões de G. gallus, usando transcrição reversa e a metodologia de PCR em tempo real. O padrão de expressão dos genes DMRT1, SOX3, SOX9, DAX1, ScII, HINTZ, HINTW e da região MHM foi analisado em embriões de galinha e animais adultos, antes, durante e depois dos períodos de diferenciação gonadal. Tais resultados foram discutidos em termos do atual conhecimento da determinação do sexo em vertebrados. Todos os genes apresentaram expressão no tecido cardíaco e/ou no mesonéfrico, além do tecido gonadal. A expressão de HINTW e MHM foi observada apenas nas fêmeas e pode desempenhar um importante papel no desenvolvimento do ovário. Os transcritos dos genes HINTZ, DMRT1, DAXI e ScII foram observados em ambos os sexos mas com expressão aumentada nos primórdios gonadais masculinos, e isto pode estar relacionado com o desenvolvimento dos testículos. MHM tem sua expressão aumentada ao mesmo tempo em que DMRT1 está menos expresso nas fêmeas, o que é indicativo de que MHM deve regular a expressão de DMRT1. Este trabalho é o primeiro a demonstrar o padrão da expressão de MHM durante o desenvolvimento gonadal, por meio de real time PCR, e relacioná-lo a análise do padrão de expressão de outros genes.

\section{ANÁLISE DO PERFIL DE EXPRESSÃO DE GENES RELACIONADOS À RESISTÊNCIA A QUIMIOTERÁPICOS NA LEUCEMIA LINFÓIDE AGUDA DA CRIANÇA E DO ADOLESCENTE}

\author{
Vanessa da Silva Silveira \\ Orientador: Prof. Dr. Luiz Gonzaga Tone \\ Tese de Doutorado apresentada em 18/02/2010
}

Com a utilizacao dos atuais protocolos de tratamento, 70-80\% dos casos de leucemia linfoide aguda (LLA) na infancia tem obtido sobrevida livre de eventos em cinco anos. Entretanto, os $20 \%$ restantes, que se mostram resistentes ao tratamento, apresentam recidivas e as causas desse insucesso no tratamento ainda permanecem desconhecidas. Dessa forma, com o intuito de melhor compreender os mecanismos moleculares que participam desse processo, o presente trabalho teve por objetivo avaliar o perfil de expressao de um painel de genes que foram previamente associados a resistencia e/ ou sensibilidade aos quimioterapicos: prednisona (F8A, CDK2AP1, BLVRB, CD69), vincristina (RPLP2, CD44, TCFL5, KCNN1, TRIM24), daunorrubicina (MAP3K12, SHOC2, PDCH9, EGR1, KCNN4) e asparaginase (GPR56, MAN1A1, CLEC11A, IGFBP7, GATA3). Para a realizacao do estudo, foram utilizadas inicialmente amostras de medula ossea de pacientes portadores de LLA pertencentes a quatro grandes centros de oncologia pediatrica do Estado de Sao Paulo e que foram submetidos ao protocolo de tratamento do GBTLI-99. A analise da expressao gênica foi realizada pela tecnica de PCR quantitativa em tempo real, utilizando-se o reagente SYBR Green, o gene GUS $\beta$ como controle endogeno e amostras de medula ossea normais como referencia. A analise dos dados de expressao genica em relacao aos diversos parâmetros clinicos e laboratoriais avaliados na LLA, demonstrou associacoes importantes entre os diversos genes estudados e variaveis clinicas importantes como contagem de glóbulos brancos ao diagnostico, presenca do antigeno CD10 (CALLA), translocacao TEL/AML1, presenca de doenca residual minima entre outras. Dentre os genes avaliados destacaram -se como possiveis marcadores de bom prognostico os genes SHOC2 e GPR56. Posteriormente, reavaliou-se o perfil de expressao desses genes em pacientes submetidos ao protocolo de tratamento europeu do grupo BFM com o intuito de verificar o padrao de expressao em pacientes com um background genetico distinto e submetidos a um protocolo terapêutico distinto. Os resultados confirmaram os dados encontrados anteriormente e demonstraram a hiperexpressao do gene $S H O C 2$ (que foi previamente associado a sensibilidade a daunorrubicina) associada ao grupo de pacientes bons respondedores, sugerindo a correlacao desse gene com criterios favoraveis de prognostico. Para verificar o nivel de interacao desse gene avaliou-se 
ainda a expressao proteica do mesmo, que confirmou os padroes de expressao genica obtidos por RQ-PCR. A funcao do gene $S H O C 2$, que embora nao esteja completamente elucidada, ja foi anteriormente descrita pela literatura, que demonstra a participacao do gene no processo de ativacao da proteina Erk pela via Ras. Finalmente para melhor compreender os possiveis mecanismos que envolvem o gene $S H O C 2$ no processo de melhor resposta a quimioterapia, utilizou-se a tecnica de RNAi para silencialo na linhagem celular leucemica Jurkat. Os resultados demosntraram a associacao da expressao do gene $S H O C 2$ com proliferacao celular e tambem com a inducao de apoptose. Esses dados sugerem que a hiperexpressao desse gene pode ser importante para o processo de sensibilidade das celulas leucemicas ao tratamento. Como conclusao, este trabalho demonstrou a associacao de diversos genes com importantes parametros clinicos da LLA e destaca principalmente o papel do gene SHOC2 como possivel alvo terapeutico para o tratamento da leucemia linfoide aguda.

\title{
DINÂMICA DE POLIMORFISMOS GENÉTICOS LIGADOS AO GENE DA HEMOFILIA A (F8) NA POPULAÇÃO BRASILEIRA
}

\section{Juliana Doblas Massaro}

Orientador: Prof. Dr. Aguinaldo Luiz Simões

Tese de Doutorado apresentada em 02/03/2010

A Hemofilia A é uma doença sanguínea condicionada por gene localizado no cromossomo X. É causada pela deficiência parcial ou total da atividade do Fator VIII (FVIII), uma glicoproteína plasmática cuja função é necessária para a coagulação normal do sangue. Devido às dificuldades encontradas para o reconhecimento direto da mutação no gene F8, o diagnóstico das portadoras é feito de forma indireta, isto é, por análise de ligação com marcadores polimórficos localizados dentro ou próximos ao gene que permite determinar a co-segregação do haplótipo e da mutação na família sob estudo e, desta maneira, detectar o estado de portadora e, eventualmente, auxiliar no diagnóstico pré-natal. O presente trabalho teve por objetivo avaliar o poder de alguns desses marcadores na diferenciação das populações e determinar o grau de sua informatividade para o diagnóstico e aconselhamento genético de famílias afetadas, bem como verificar o eventual uso forense de tais marcadores. Foram então determinadas as frequências alélicas e haplotípicas, iversidade genética, diferenciação populacional, desequilíbrio de ligação e composição ancestral de quatro microssatélites intragênicos (IVS 1, IVS 13, IVS 22, IVS 25.3), localizados em introns do F8, e um extragênico (IKBKG) em amostras de populações brasileiras urbanas (indivíduos normais de São Paulo, Rio Grande do Sul e Pernambuco), de quilombos (Mimbó, Sítio Velho e Gaucinha localizados no Estado do Piauí) e Ameríndios (Tikúna, Baníwa e Kashináwa). As análises, quando cabível, incluíram um grupo de pacientes hemofílicos. O DNA dos sítios polimórficos foi amplificado por PCR, os produtos separados em PAGE e corado por nitrato de prata. Para as análises estatísticas foram empregados programas já considerados de uso rotineiro. Os parâmetros de diversidade mostraram diferenças entre as amostras populacionais analisadas. Tais diferenças regionais nas frequências alélicas devem ser levadas em conta quando o diagnóstico indireto da Hemofilia A estiver sendo realizado. Com exceção do IKBKG, todos os demais microssatélites apresentaram altas taxas de heterozigose. Usando tais marcadores, o diagnóstico foi possível em 10 das 11 famílias analisadas. Os microssatélites IVS 22, IVS 1, IVS 13, IVS 25.3 e IKBKG foram informativos em 63,6\% (7/11), 54.5\% (6/11), 54.5\% (6/11), 45.5\% (5/11) e 18.2\% (2/11) dos casos, respectivamente, demonstrando a eficácia do uso desses microssatélites no diagnóstico pré-natal e na identificação de portadoras na população brasileira.

\section{FREQUÊNCIA DE ANEUPLOIDIAS EM CÉLULAS GERMINATIVAS DE HOMENS FUMANTES}

\author{
Ciro Silveira e Pereira \\ Orientadora: Profa. Dra. Lucia Regina Martelli \\ Dissertação de Mestrado apresentada em 03/03/2010
}

As aneuploidias cromossômicas em espermatozóides estão diretamente relacionadas à infertilidade, elevando o risco de anomalias congênitas e perda fetal. Apesar da idade materna avançada ainda permanecer como um dos poucos fatores de risco bem estabelecido, outros fatores têm sido identificados como contribuintes potenciais para o aumento de aneuploidias, entre eles o etilismo, o tabagismo e a exposição ocupacional a pesticidas. No presente estudo, utilizando a técnica de FISH, foram avaliadas as frequências de dissomias dos cromossomos 3, 13, 21, 22, X e Y em espermatozóides de dez homens fumantes, sendo comparadas ao grupo controle de sete homens férteis, não fumantes. Os indivíduos de ambos os grupos apresentaram cariótipo normal. A frequência total de dissomias apresentou aumento significativo no grupo fumante $(2,74 \%)$ quando comparada ao grupo controle (2,03\%). O erro em meiose I para o par sexual (dissomia XY) 
e dissomias envolvendo o cromossomo 3 apresentaram aumento significativo nos fumantes, assim como a frequência de diploidias com erro iniciado em meiose I. Nossos resultados sugerem associação entre o hábito do tabagismo e a não redução na meiose I. Não foi encontrada diferença estatisticamente significante entre a frequência de dissomias, quando os fumantes foram separados em indivíduos que fumavam menos e mais do que 20 cigarros por dia. A investigação citogenética molecular de células germinativas mostrou-se ferramenta fundamental para a elucidação dos mecanismos de segregação meiótica, possibilitando a identificação de possíveis fatores responsáveis pela infertilidade.

\title{
EFEITOS DA INIBIÇÃO DE AURORA-QUINASES EM LINHAGENS CELULARES DE GLIOBLASTOMA
}

\author{
Kleiton Silva Borges \\ Orientador: Prof. Dr. Luiz Gonzaga Tone \\ Dissertação de Mestrado apresentada em 19/03/2010
}

Os astrocitomas são tumores cerebrais que surgem dos astrócitos, células gliais que tem a função de fornecer suporte estrutural e funcional aos neurônios. Segundo a Organização Mundial da Saúde (OMS), estes tumores são classificados de acordo com características celulares e de proliferação observadas no tecido, sendo então subdivididos em quatro grupos: Astrocitoma pilocítico, Astrocitoma difuso, Astrocitoma Anaplásico e Glioblastoma. Este último é o mais agressivo e dentre as diversas neoplasias possui um dos piores prognósticos. Apesar dos avanços diagnósticos e terapêuticos, ainda não há medicamentos que melhorem significativamente a sobrevida dos pacientes com glioblastoma. Vários estudos têm buscado novos alvos terapêuticos para o tratamento do câncer, e dentre estes, os genes das Auroraquinases têm sido amplamente estudados em diversos tumores. Esta família compreende três homólogos de quinase de serina/treonina, o Aurora-A, B e C, que atuam em vários processos do ciclo celular, tais como, maturação dos centrossomos, organização do fuso mitótico e ancoragem das proteínas do fuso ao cinetocoro dos cromossomos. Em diferentes tipos de neoplasias, dois membros desta família, Aurora-A e o Aurora-B, têm sido encontrados hiperexpressos, e desta forma acredita-se que os mesmos desempenham um papel importante no estabelecimento do câncer. No caso dos glioblastomas, a hiperexpressão dos genes Aurora-A e Aurora- $B$ tem sido previamente relatada. No presente trabalho, foram analisados os efeitos do ZM447439 (inibidor de aurora-quinases), associado ou não com a Temozolomida, nas linhagens celulares de glioblastoma U343p53sel e U251p53mut, através de estudos de proliferação celular, índice mitótico e sobrevivência clonogênica após irradiação. A expressão dos genes foi avaliada por RQ-PCR. Ambas as linhagens hiperexpressam os genes Aurora-A e Aurora- $B$. O tratamento com o ZM inibiu a proliferação das linhagens em dose e tempo-dependentes. A capacidade clonogênica foi reduzida após o tratamento, sensibilizando as células para a irradiação. Houve uma diminuição do índice mitótico das linhagens após o tratamento, sendo mais intenso na linhagem U343p53wt. Estes dados sugerem que as Auroras kinases podem ser alvos interessantes para o tratamento futuro de glioblastoma e estudos subsequentes devem ser realizados para confirmar este potencial.

\section{ESTUDO POPULACIONAL E MOLECULAR DE Nannotrigona testaceicornis COCKERELL (HYMENOPTERA, APIDAE, MELIPONINI) ATRAVÉS DO DNA MITOCONDRIAL}

\author{
Amanda Freire De Assis \\ Orientador: Prof. Dr. Ademilson Espencer Egea Soares \\ Dissertação de Mestrado apresentada em 26/03/2010
}

Nannotrigona testaceicornis é uma espécie de abelha sem ferrão sendo que seus ninhos são largamente encontrados na zona urbana. Os meliponíneos estão entre os principais polinizadores da flora brasileira, no entanto, muitas espécies estão seriamente ameaçadas de extinção em consequência da perda do habitat e isolamento causados principalmente pelo desmatamento, uso indiscriminado de defensivos agrícolas e grandes queimadas, pois tais alterações resultam em ecossistemas fragmentados, formando mosaicos de vegetação remanescente, mergulhados numa paisagem antropizada. Nesse processo, grandes populações são reduzidas e subdivididas, o que pode acarretar alterações ecológicas e genéticas. Estudos populacionais de espécies de meliponíneos ainda são muito escassos, fazendo-se necessário a ampliação desses estudos para uma melhor compreensão da dinâmica populacional dessas abelhas. Neste contexto, este trabalho teve como objetivo a realização de um estudo populacional em ninhos amostrados nos estados de São Paulo e Minas Gerais, utilizando-se o mtDNA como ferramenta molecular. As análises através de PCR+RFLP de 05 regiões do mtDNA não revelaram polimorfismos nas populações estudadas, sendo detectado apenas um haplótipo. O estudo através do sequenciamento de um fragmento do gene COI I de sessenta operárias provenientes do campus da USP-RP, Ribeirão Preto, 
Bonfim Paulista, Franca, Campinas, São Paulo, Uberlândia, Várzea da Palma, Viçosa e Caratinga, revelou a presença de cinco haplótipos nas populações amostradas dos quais três eram exclusivos de uma única populaçaõ e um era compartilhado por $70 \%$ das populações. A média da diversidade haplotípica $(\mathrm{Hd}=0,264)$, e a diversidade nucleotídica $(?=0,00386)$ foram avaliadas revelando uma baixa divergência entre os haplótipos encontrados. As análises estatísticas revelaram que as populações estudadas estão estruturadas em três grupos, sendo esta estruturação um reflexo de eventos antigos em consequência de mudanças climáticas devido às glaciações do Pleistoceno levando a um gargalo populacional e posterior dispersão, juntamente com a barreira geográfica do mosaico de montanhas do complexo da "Serra do Espinhaço" que isolou duas das populações estudadas (Viçosa e Caratinga) levando à diferenciação das mesmas.

\title{
ESTUDO CITOGENÉTICO DE INDIVÍDUOS AFETADOS POR DEFICIÊNCIA MENTAL EM TRÊS APAES DA REGIÃO DE RIBEIRÃO PRETO
}

\author{
Ludmila Serafim de Abreu \\ Orientador: Prof. Dr. João Monteiro de Pina Neto \\ Dissertação de Mestrado apresentada em 26/03/2010
}

Em estudos etiológicos sobre a deficiência mental (DM), as anomalias cromossômicas, tanto numéricas quanto estruturais, são fatores que apresentam frequência relativa significante. O objetivo deste trabalho foi estudar as frequências e os tipos de anomalias cromossômicas em afetados por DM nas APAEs (Associação de Pais e Amigos dos Deficientes) de Batatais, Altinópolis e Serrana, objetivando conhecer melhor a contribuição destas anomalias na DM nessa região, caracterizando os tipos e as frequências das aberrações cromossômicas observadas e compará-las entre as APAEs. Pacientes com suspeita de anomalias cromossômicas foram selecionados para o estudo. O critério usado para a seleção da amostra foi a realização do cariótipo em todos os afetados por DM com anomalias estruturais maiores e/ou menores. A análise citogenética foi feita através de cultura de linfócitos do sangue periférico e a coloração utilizada foi banda $\mathrm{G}$, sendo analisadas 20 metáfases por paciente. Dos 505 indivíduos avaliados nas três APAES, 265 realizaram estudo citogenético, sendo encontradas 61 alterações cromossômicas (12,1\% do total e 23,0\% dos selecionados para cariótipo). Na APAE de Batatais, dos 305 indivíduos avaliados, 174 realizaram cariótipo, sendo encontradas 33 (10,8\% do total) anomalias cromossômicas. Em Altinópolis, dos 107 indivíduos avaliados, 54 realizaram cariótipo, sendo observados 16 cariótipos anômalos (14,9\% do total). Na APAE de Serrana, dos 93 indivíduos avaliados, 37 realizaram cariótipo, sendo encontradas 12 (12,9\% do total) anomalias cromossômicas. Esses resultados demonstram que anomalias cromossômicas contribuem significativamente para a etiologia da DM e que a citogenética clássica possui importantes implicações na prática médica para o diagnóstico dos indivíduos afetados, assim como, para o aconselhamento genético das famílias. Além disso, observa-se que a APAE de Batatais, por apresentar uma porcentagem menor de indivíduos afetados por DM grave, 60,7\%, possui uma menor incidência de anomalias cromossômicas quando comparada as APAEs de Altinópolis e Serrana que apresentam uma frequência de 87,8\% e 83,9\% de indivíduos com DM grave, respectivamente, indicando que alterações cromossômicas são mais frequentes em indivíduos afetados por DM grave.

\section{MECANISMOS ENVOLVIDOS NAS RESPOSTAS CELULARES AO ANTITUMORAL CISPLATINA ASSOCIADO AO INIBIDOR DE PI3K (LY294002) EM LINHAGENS DE GLIOMA}

\author{
Patricia de Oliveira Carminati \\ Orientador: Profa. Dra. Elza Tiemi Sakamoto Hojo - FFCLRP-USP \\ Tese de Doutorado apresentada em 26/03/2010
}

Os gliomas malignos são os tumores primários do sistema nervoso central mais comuns, sendo os mais agressivos e mais difíceis de serem tratados. Dessa maneira, novas estratégias de tratamento, buscando aumentar a taxa de indução de morte celular, têm sido investigadas. Neste estudo, foram analisadas as respostas celulares ao tratamento com a cisplatina, associada ou não ao LY294002 (inibidor da família de proteínas PI3K e DNA-PK) em células de glioma, linhagens U343, U87 (ambas proficientes para TP53), além de MO59K e MO59J (proficiente e deficiente para DNA-PK, respectivamente). Os resultados mostraram que a cisplatina causou uma grande diminuição na porcentagem de células sobreviventes (linhagens U343 e U87), sendo que o LY294002 aumentou o efeito da cisplatina. As células U343 sofreram apoptose em resposta à cisplatina e cisplatina+LY294002, o que não foi observado nas células U87. Também foi detectado um leve bloqueio em S nas células U343 após o tratamento com a cisplatina. A linhagem MO59K foi resistente à cisplatina em comparação à MO59J, sendo observado um bloqueio na fase $\mathrm{S}$ do ciclo celular nas células MO59K. A análise dos níveis de 
expressão protéica revelou que TFIIHp80 (função associada ao reparo do DNA) foi expressa em todos os tratamentos empregados. PCNA (duplicação e reparo do DNA) se expressou em todas as condições testadas (U343), apresentando um aumento de expressão dependente da concentração nas células MO59K após o tratamento com a cisplatina, condizente com o bloqueio em S. Por outro lado, não houve uma alteração na expressão de PCNA nas células MO59J. A expressão de SAPK/JNK apresentou níveis basais nas células não tratadas. As proteínas envolvidas na percepção e sinalização dos danos induzidos no DNA (como ATR, CHK1 e TP53) apresentaram uma maior expressão nas amostras tratadas com cisplatina e cisplatina+LY294002. Adicionalmente, verificou-se a formação de foci de $\gamma \mathrm{H} 2 \mathrm{AX}$ nas células tratadas com cisplatina e cisplatina+LY294002, condizente com a geração de DSBs pela cisplatina como lesões secundárias. A análise da expressão gênica por cDNA microarrays mostrou 108 genes significativamente modulados (28 induzidos e 80 reprimidos) pelo tratamento com cisplatina; 274 genes (94 induzidos e 180 reprimidos) modulados pelo tratamento com cisplatina+LY294002, e 33 genes (6 induzidos e 27 reprimidos) modulados por LY294002. O tratamento combinado causou uma maior alteração transcricional nas células U343 relativamente aos demais tratamentos (cisplatina ou LY294002). Os genes modulados estão relacionados principalmente com os processos de 13 reparo do DNA (RAD51D, RAD52, ATR, NBS1 e PRKDC), apoptose (FOXO3A, CASP8AP2, BIRC2, CAV1 e DUSP22), controle do ciclo celular e proliferação (CDC14A, SESN1, SRPK2, EGFR e MAPK6), e adesão celular (CDH13, ADAM12, SPP1 e STOML2). O gene PRKDC, o qual codifica a DNA-PK, foi reprimido nas células tratadas com cisplatina+LY294002 e LY294002, confirmando o efeito inibitório do LY294002. Os padrões de expressão de alguns genes (PRKDC, DUSP22, FEN1, BTG2, CAV1 e RAD52) por PCR em tempo real foram similares aos perfis de expressão gerados pelo método de microarrays. Em conclusão, os resultados apresentados demonstraram que LY294002 associado à cisplatina aumentou os efeitos causados pela droga sozinha, fato que pode ser devido à inibição de DNA-PK, a qual está envolvida no reparo NHEJ (non-homologous end joining). Os resultados obtidos também indicam que a DNA-PK é um determinante crítico da sobrevivência celular após exposição à cisplatina, e a falta de um bloqueio em $\mathrm{S}$ nas células MO59J é provavelmente responsável pelo aumento de morte celular após o tratamento com a cisplatina. O presente estudo sugere que a DNA-PK constitui um alvo terapêutico eficiente para sensibilizar as células de glioma à cisplatina.

\title{
PREDIÇÃO in silico DE EPÍTOPOS DE MICRORGANISMOS COM IDENTIDADE A AUTOANTÍGENOS HUMANOS
}

\author{
André Luis da Silva Breve \\ Orientadora: Profa. Dra. Silvana Giuliatti \\ Dissertação de Mestrado apresentada em 31/03/2010
}

A origem das doenças autoimunes é multifatorial, sendo que envolve condições ambientais e predisposição genética, dificultando sua identificação. Muitos pesquisadores têm estudado a associação entre agentes infecciosos e autoimunidade, a qual pode ser disparada pelo processo conhecido por mimetismo molecular. Neste caso, respostas imunes cruzadas envolvendo antígenos próprios têm sido documentadas. O presente projeto tem como objetivo a busca in silico por associações entre epítopos de microrganismos e autoantígenos humanos. Iniciaram-se as análises pela identificação de semelhanças de sequências de aminoácidos entre epítopos de microrganismos e autoantígenos humanos por meio do alinhamento local de sequências efetuado pelo programa BLASTP. As sequências de epítopos dos microrganismos e autoantígenos humanos foram previamente adquiridas nos bancos de dados Immune Epitope Database and Analysis Resource (IEDB) e no Genbank, respectivamente. Foram também realizadas modelagens de estruturas proteicas para o antígeno e o autoantígeno que obtiveram melhores valores de alinhamento, com base no valor do $E$-value, por meio dos programas Modeller e Rosetta. Por fim, a predição de epítopos foi executada, pelo uso dos softwares NetMHC e NetMHCII, para avaliar a possibilidade de epítopos de microrganismos e de autoantígenos humanos se associarem aos mesmos alelos de HLA. Como resultado, foram encontradas similaridades tanto de sequências proteicas quanto de afinidade a 4 tipos de alelos de HLA entre um epítopo do antígeno LSA-1 de Plasmodium falciparum e o autoantígeno de miosina, o que sugere uma associação entre eles, atingindo o objetivo deste trabalho. 


\title{
Imunologia Básica e Aplicada
}

\section{AVALIAÇÃO DA EXPRESSÃO DE RECEPTORES PARA IFN- $\gamma$, IL-4, IL-10 E IL-12 EM ANIMAIS COM SUSCEPTIBILIDADE DISTINTA À INFECÇÃO POR Mycobacterium tuberculosis}

\author{
Cássia Alves Sérgio \\ Orientadora: Profa. Dra. Vânia Luiza Deperon Bonato \\ Dissertação de Mestrado apresentada em 09/02/2010
}

O entendimento da relação patógeno, hospedeiro e resposta imune é essencial para o desenvolvimento de novas medidas que sejam realmente eficazes para reduzir o número de casos de tuberculose no mundo, doença que causa 7 milhões de mortes por ano (WHO, 2008). Embora o progresso na identificação de células, mediadores solúveis e mecanismos que participam da resposta imune na infecção por Mycobacterium tuberculosis tenha sido notório nos últimos anos, ainda pairam questões sobre a relação desse patógeno com o hospedeiro. Por exemplo, apesar de um terço da população mundial estar infectada com M. tuberculosis, apenas 5-10\% dos indivíduos infectados desenvolvem a patologia em determinada fase da vida, enquanto as demais pessoas mantêm a infecção latente. Por que isso ocorre, o que diferencia a resposta imunológica dos indivíduos com infecção latente daqueles que tem a forma ativa e progressiva da doença ainda permanece uma indagação. Nesse contexto, a busca por biomarcadores que possam predizer o estágio da infecção, susceptibilidade ou resistência do hospedeiro está entre as metas de diferentes grupos que trabalham para compreender melhor esta patologia. Neste estudo nós avaliamos a expressão dos receptores para IFN- $\gamma$, IL-4, IL-10 e IL-12, além da expressão dos receptores DC-SIGN, TLR2 e TLR4, em duas linhagens de camundongos BALB/c e C57BL/6, que possuem capacidade distinta de controlar a infecção por M. tuberculosis. Dois períodos da infecção foram avaliados: 30 dias, que corresponde à fase inicial, e 70 dias, que corresponde à fase tardia do modelo experimental, de acordo com estudos prévios de nosso grupo. Os dados obtidos referentes à expressão dos receptores para IFN- $\gamma$, IL-10 e IL-12 em animais BALB/c e C57BL/6 nos dois períodos avaliados sugerem que diferenças genéticas do hospedeiro contribuem para a expressão diferencial desses receptores. Nós observamos baixa expressão da cadeia R1 do receptor para IFN- $\gamma$ nas células CD11b+ na fase tardia e a regulação positiva na expressão da cadeia do receptor para IL-10 nas células CD11b+e células CD11c+ do pulmão de animais BALB/c aos 30 dias de infecção. Além disso, encontramos aumento significativo na expressão do receptor para IFN- $\gamma$ nas células CD11b+ de animais C57BL/6 e baixa expressão do receptor para IL-10. Esses dados sugerem que a modulação esses receptores pode contribuir para o controle da infecção na fase tardia. Em adição, também constatamos aumento na expressão do receptor para IL-12 nas células CD4+ e CD8+ do pulmão de animais C57BL/6, e alta expressão do receptor TLR2 nas células CD11b+ de animais C57BL/6 na fase tardia da infecção. Embora seja um estudo descritivo, os dados gerados a partir do desenvolvimento desse projeto sugerem que novos marcadores imunológicos podem ser identificados nas distintas fases da infecção por $M$. tuberculosis, sendo tais fases associadas ou não ao controle do crescimento dos bacilos. Estudos funcionais poderão contribuir para confirmar o papel desses receptores e poderão abrir perspectivas para que tais receptores sejam avaliados em amostras de pacientes com tuberculose ativa, latente e em contatos de pacientes, com a finalidade de que se confirme o potencial como biomarcadores.

\section{PAPEL DE CCR4 NA INFECÇÃO POR Paracoccidioides brasiliensis: CONTROLE DA MIGRAÇÃO DE CÉLULAS T CD4+CD25+ PARA O LOCAL DA LESÃO}

\section{Fernanda Agostinho Rocha}

Orientador: Prof. Dr. João Santana da Silva

Dissertação de Mestrado apresentada em 22/02/2010

A paracoccidioidomicose (PCM) é uma doença crônica, granulomatosa, causada pela inalação de propágulos aéreos do fungo Paracoccidioides brasiliensis. As células T reguladoras $\mathrm{CD}^{+} \mathrm{CD} 25^{+}$(Treg) estão presentes em lesões pulmonares de pacientes com PCM e podem estar envolvidas nos casos de recidivas, comumente relacionadas a esta micose. Como a migração dessas células é parcialmente dependente do receptor de quimiocina CCR4, avaliamos o papel deste receptor durante a infecção por $P$. brasiliensis em camundongos C57BL/6 e geneticamente deficientes de CCR4 $\left(\mathrm{CCR}^{-/}\right)$. Os dados obtidos neste estudo demonstraram que no dia 3 após a infecção, camundongos CCR $4^{--}$apresentam aumento significativo $(\mathrm{p}<0,05)$ da migração de células $\mathrm{CD} 11 \mathrm{~b}^{+}$e CD11 $\mathrm{b}^{+} \mathrm{CD} 11 \mathrm{c}^{+}$para os pulmões, resultando em extensa lesão inflamatória, porém, reduzida produção de NOS2. Até a segunda semana após a infecção os camundongos CCR $4^{-1-}$ 
são incapazes de controlar o crescimento e disseminação das leveduras, apresentando maior taxa de mortalidade durante esse período. A ausência de CCR4 prejudica a migração de linfócitos T para as lesões, sendo que o número de células T $\mathrm{CD}^{+}, \mathrm{CD}^{+}$e $\mathrm{CD} 4^{+} \mathrm{CD} 25^{+}$foi significativamente $(\mathrm{p}<0,05)$ diminuída e o número de células Foxp3 $3^{+}$no pulmão foi menor quando comparado com camundongos selvagens. Após a transferência adotiva de células T CD $4^{+} \mathrm{CD} 25^{+}$provenientes de camundongos selvagens para CCR4 ${ }^{-/-}$ocorreu uma diminuição significativa $(\mathrm{p}<0,05)$ da quantidade de fungos nos pulmões, enquanto que a transferência de células $\mathrm{CD}^{+} \mathrm{CD} 25^{-}$não alterou significativamente o crescimento das leveduras. Em conjunto os resultados revelam que CCR4 modula a migração e a função supressora das células T reguladoras $\mathrm{CD}^{+} \mathrm{CD} 25^{+}$ controlando a sobrevivência do fungo dentro dos granulomas.

\title{
FRAGMENTOS DE ANTICORPOS HUMANOS (SCFV) CAPAZES DE INIBIR, in vitro E in vivo, AÇÕES TÓXICAS DO VENENO DE ABELHAS AFRICANIZADAS
}

\author{
Jaqueline Carlos Funayama \\ Orientador: Prof. Dr. José Elpidio Barbosa \\ Tese de Doutorado apresentada em 22/02/2010
}

As abelhas africanizadas trouxeram inúmeras vantagens aos apicultores, mas essas possuem comportamentos indesejáveis tais como instinto de defesa da colônia e ataques em massa, resultando em acidentes graves, podendo levar a morte. O veneno de abelha é uma mistura complexa com atividades tóxicas e um tratamento efetivo para casos de intoxicação ainda é esperado. Uma alternativa para a produção do antiveneno é a tecnologia de Phage Display, que permite a produção de anticorpos humanos, sem causar a "Doença do soro" ou anafilaxia nos pacientes tratados. O objetivo deste trabalho foi produzir fragmentos de anticorpos monoclonais humanos (scFv), capazes de inibir ações tóxicas do veneno bruto de abelhas africanizadas. Utilizou-se um protocolo de imobilização das proteínas do veneno bruto em fase sólida, para seleção de fagos-anticorpos contra as mesmas. Duas seleções, de 4 e 3 turnos, para o veneno bruto e uma re-seleção para melitina foram realizados. Os fagos-anticorpos policlonais foram analisados por ensaio de ELISA e os melhores turnos foram escolhidos para a produção de placas de cultura de fagos anticorpos monoclonais. Os seis melhores clones foram selecionados por ensaio de ELISA e esses foram utilizados para a produção de fragmentos de anticorpos solúveis. Condições de produção e purificação foram estabelecidas e os clones foram testados quanto a sua capacidade de inibição do veneno. Após ensaio hemolítico de ponto final, 3 clones foram selecionados e testados em ensaio de ELISA para detecção da ligação à melitina e fosfolipase $\mathrm{A}_{2}$. Dois clones $(\mathrm{C} 5$ e C12) foram positivos para melitina e o clone A7 foi positivo para fosfolipase $A_{2}$. Os 3 clones foram testados em ensaio cinético de inibição de hemólise individualmente ou sinergicamente. Uma combinação sinérgica dos clones A7 e C12 foi a que apresentou melhores resultados e foi a escolhida para os ensaios de inibição de miotoxicidade e letalidade. A combinação de anticorpos conseguiu inibir a ação miotóxica do veneno in vivo e aumentou a sobrevida dos animais que receberam o tratamento.

\section{CARACTERIZAÇÃO DAS POPULAÇÕES DE CÉLULAS T REGULADORAS E CÉLULAS T PRODUTORAS DE IL-17 DURANTE O DESENVOLVIMENTO DO DIABETES INDUZIDO POR ESTREPTOZOTOCINA E AVALIAÇÃO DO POTENCIAL TERAPÊUTICO DE CÉLULAS ESTROMAIS MESENQUIMAIS NESSE MODELO EXPERIMENTAL}

\author{
Juliana Navarro Ueda Yaochite \\ Orientador: Prof. Dr. Júlio César Voltarelli \\ Dissertação de Mestrado apresentada em 23/02/2010
}

O diabetes mellitus do tipo 1 é uma doença autoimune órgão-específica, mediada por células T e é caracterizada pela destruição seletiva de células $\beta$ pancreáticas produtoras de insulina. O tratamento convencional é feito com insulina e outras abordagens terapêuticas são limitadas, como o transplante de ilhotas pancreáticas. Esse cenário estimula novas pesquisas em busca de alternativas terapêuticas, tais como o tratamento com células-tronco. As células estromais mesenquimais (MSCs) possuem capacidade de diferenciar-se em outros tipos celulares, de migrar para tecido lesados, de modular o sistema imunológico e de secretar diversas citocinas e fatores de crescimento. O diabetes experimental pode ser induzido através de múltiplas doses de estreptozotocina (STZ) em camundongos de linhagens suscetíveis, no qual o efeito tóxico da droga promove a liberação de antígenos das células beta pancreáticas e estimula uma reação imune contra essas células. Muitos estudos têm mostrado a relaçãode células T reguladoras e células T produtoras de IL-17 (Thl7 e Tc17) na patogênese de diversas doenças autoimunes, no entanto, a real função dessas células no diabetes não está 
totalmente esclarecida. Desta forma, o presente estudo teve dois objetivos principais: (I) avaliar a população de células T reguladoras e células T produtoras de IL-17 no modelo de diabetes induzido por STZ em camundongos C57BL/6 e (II) avaliar o potencial terapêutico de células estromais mesenquimais (MSCs) humanas nesse modelo experimental. Os períodos iniciais de desenvolvimento do diabetes foram marcados por uma diminuição na expressão de moléculas reguladoras CTLA-4, GITR e PD-1 na superfície das células T CD4+CD25+ no baço dos animais diabéticos e aumento na quantidade de células T CD4+CD25+ positivas para Foxp3 e células T produtoras de ) IL-17 nos linfonodos pancreáticos desses animais. Ainda nesta fase de progressão da doença, observamos níveis aumentados de IL,6, IFN- $\gamma$ e TNF- $\alpha$ no pâncreas dos animais tratados com STZ e não observamos aumento na concentração de IL-17, sugerindo a participação de células Th1 na destruição das células beta pancreáticas. Nos períodos mais tardios de desenvolvimento da doença, observamos aumento na expressão das moléculas CTLA-4, GITR e PD-1 na superfície das células T CD4+CD25+, bem como aumento nos níveis de IL 10 no pâncreas dos animais diabéticos, sugerindo um estágio de regulação e finalização da resposta imune. Com relação ao potencial terapêutico das MSCs no tratamento do diabetes experimental, observamos que duas infusões de MSCs humanas em camundongos C57BL/6 diabéticos foram capazes de reverter a hiperglicemia dos animais diabéticos, e, além disso, os animais tratados apresentaram aumento na massa de células beta produtoras de insulina, sugerindo um possível processo de regeneração promovido pelo transplante de MSCs. Desta forma, podemos sugerir que as células T produtoras de IL-17 participam nos períodos iniciais de desenvolvimento do diabetes neste modelo experimental, não atuando de forma direta na destruição das células beta, mas ficando retidas nos linfonodos pancreáticos. Além disso, os mecanismos reguladores da resposta imune começam a aparecer nos períodos mais tardios de progressão da doença. O tratamento com MSCs se mostrou eficaz podendo ser realizado de forma não restrita ao MHC.

\title{
AVALIAÇÃO DO EFEITO IMUNOMODULADOR DE ANTÍGENOS MICOBACTERIANOS NA ALERGIA EXPERIMENTAL
}

\author{
Denise Morais da Fonseca \\ Orientadora: Profa. Dra. Vânia Luiza Deperon Bonato \\ Tese de Doutorado apresentada em 14/03/2010
}

Dados epidemiológicos e experimentais mostram que exposição a diferentes espécies de micobactéria, bem como a antígenos micobacterianos, pode modular a resposta alérgica. Entretanto, a imunização com micobactérias viáveis pode não ser aplicável para imunoterapia em humanos. A administração de agonistas de receptores do tipo Toll (TLR) também pode modular a resposta alérgica e vários ensaios clínicos motram seu potencial promissor. Neste trabalho, nós avaliamos o efeito terapêutico do antígeno micobacteriano Hsp65, utilizado como vacina de DNA (DNA-HSP65) ou DNA encapsulado em lipossomas (DRV-DNA-HSP65) no modelo asma experimental induzida pela sensibilização com ovalbumina (OVA). Em adição, nós também utilizamos proteínas de filtrado de cultura de Mycobacterium tuberculosis em presença de oligodeoxinucleotídeos $\mathrm{CpG}$ (PFC/CpG) com o intuito de avaliar se esses antígenos micobacterianos poderiam acentuar o efeito de modulação da resosta alérgica conferido pela terapia com $\mathrm{CpG}$ apenas. Camundongos previamente sensibilizados e desafiados com OVA foram tratados com DNA-HSP65 pela via intramuscular, DRV-DNA-HSP65 pela via intranasal ou com PFC/CpG pela via subcutânea. Quinze dias após o tratamento, os animais receberam um segundo desafio com OVA e 72 horas após o desafio, os animais alérgicos tratados com DNA-HSP65, DRV-DNA-HSP65 or PFC/CpG exibiram uma redução significativa inflamação pulmonar; eosinofilia e produção de IL-4, IL-5, IL-13, TSLP e eotaxina no lavado broncoalveolar (LBA); anticorpos séricos IgG1 e IgE alérgeno-específicos e produção de citocinas de padrão Th2 por células de baço estimuladas com OVA. Paralelamente, em relação ao grupo alérgico não tratado, o tratamento com DNAHS65 aumentou a produção de IL-10, enquanto o tratamento com PFC/CpG induziu aumento da produção de IFN- no LBA e em sobrenadante de cultura de células de baço estimuladas com OVA. O efeito imunomodulador das células específicas para Hsp65 e PFC foi confirmado pela redução da eosinofilia em LBA de camundongos alérgicos que receberam transferência de células de baço provenientes de animais transgênicos para a proteína GFP (Green-Fluorescent-Protein) que foram previamente imunizados com DNA-HSP65 ou PFC/CpG. Os linfócitos GFP+ transferidos migraram para o LBA, pulmão e linfonodos drenantes dos animais alérgicos. Por isso, foi realizado um experimento no qual camundongos tratados com DNA-HSP65 ou PFC/CpG receberam uma dose adicional de Hsp65 recombinante (rHsp65) ou PFC, respectivamente, pela via intranasal. A administração desses antígenos pela via intranasal aumentou os efeitos terapêuticos de DNA-HSP65 e PFC/CpG e induziu uma redução mais acentuada da eosinofilia em relação aos animais tratados apenas pela via parenteral. As células específicas para Hsp65 ou PFC transferidas secretavam IL-10 e IFN- $\gamma$. Dessa forma, o papel de IL-10 e IFN- $\gamma$ na modulação da resposta alérgica pela imunoterapia foi confirmado quando os efeitos terapêuticos de DNA-HSP65 e PFC/ CpG foram ausentes em camundongos IL-10 -/- e IFN- $\gamma$-/-, respectivamente. Além disso, o efeito protetor das células 
provenientes de animais imunizados com DNA-HSP65 foi parcialmente dependente da expressão de MyD88 e não estava relacionado com a expressão de TLR2 ou FAS. Paralelamente, os efeitos terapêuticos de PFC/CpG foram totalmente dependentes de FAS e parcialmente dependentes de MyD88. Esses resultados mostram que é possível realizar uma imunoterapia livre de alérgeno usando antígenos micobacterianos. A imunoterapia com DNA-HSP65 modulou a resposta alérgica por mecanismos dependentes de IL-10 e MyD88 enquanto o efeito terapêutico de PFC/CpG foi dependente de IFN- $\gamma$, FAS e MyD88.

\title{
ANÁLISE DA EXPRESSÃO DE GENES RELACIONADOS A CÉLULAS T REGULADORAS, Th17, Th1 E Th2 EM PACIENTES COM DOENÇAS AUTOIMUNES SUBMETIDOS AO TRANSPLANTE AUTÓLOGO DE CÉLULAS-TRONCO HEMATOPOIÉTICAS
}

\author{
Gabriela Trentin Scortegagna \\ Orientador: Prof. Dr. Júlio César Voltarelli \\ Dissertação de Mestrado apresentada em 31/03/2010
}

Ensaios clínicos têm demonstrado que a imunoablação seguida de transplante autólogo de células tronco hematopoiéticas (TACTH) é capaz de suprimir a atividade inflamatória em pacientes com doenças autoimunes (DAIs) e pode induzir remissões clínicas prolongadas nesses pacientes, mas o mecanismo de ação do TACTH ainda não é bem esclarecido. O objetivo deste trabalho foi analisar a expressão de genes relacionados a células T reguladoras, Th17, Th1 e Th2 em pacientes com diabete melito tipo 1 (DM-1, N=22) e pacientes com esclerose múltipla (EM, N=17), sequencialmente após o TACTH. As células mononucleares do sangue periférico (PBMC) foram isoladas dos controles e de pacientes nos períodos pré-transplante, D+180, D+360, D+540, D+720, D+900 e D+1080 pós-transplante. As PBMC foram utilizadas para extração de RNA, síntese de cDNA, quantificação da expressão por PCR em tempo real dos genes IL-10, TGF- $\beta$, Foxp3, CD25, GITR, CTLA-4, PD-1, IL-17, IL-23, IL-25, IL-27, GATA3, STAT-6, IL-6, IL-4, IFN- $\gamma$, TNF- $\alpha$, STAT-1, STAT-4, STAT-3, IL-21. Os resultados de expressão gênica foram representados por fold change calculados através do método $2^{\wedge}-\Delta \Delta C T$. Em relação aos controles, os pacientes com DM-1, no período PRE, apresentaram expressão elevada dos genes IL-10 (8.5x, p<0.0001), CTLA-4 (1.2x, p=0.01), IL-27 (2.5x, p=0.04) e GATA3 (4.1x, p=0.001), e após o transplante, em pelo menos um período do seguimento, essa expressão atingiu níveis normais, enquanto os genes IL-6 e IL-17 aumentaram sua expressão, em 29.5x $(\mathrm{p}<0.0001)$ e $2.9 \mathrm{x}(\mathrm{p}=0.01)$ respectivamente, ambos no $\mathrm{D}+540$. Os pacientes com EM apresentaram no período PRE, em relação aos controles, níveis de expressão elevados dos genes IL-10 (12.3x, p<0.0001), PD-1 (2.8x, p=0.04), IL-6 (5.4x, p=0.04), IL-27 (13.4x, p<0.0001), e diminuídos do gene CD25 (0.2x, p=0.01), e em pelo menos um período do seguimento póstransplante, exceto para IL-27, esses níveis se normalizaram, enquanto CTLA-4 e TNF- $\alpha$ elevaram sua expressão, respectivamente, em $1.4 \mathrm{x}(\mathrm{p}=0.02, \mathrm{D}+720)$ e $11.6 \mathrm{x}(\mathrm{p}=0.001, \mathrm{D}+540)$. Esses resultados sugerem que a terapia de IAD/TACTH modulou a expressão destes genes, em ambas as doenças, o que pode ter contribuído para a remissão clínica desses pacientes.

\section{Neurologia}

\section{ASPECTOS CLÍNICOS E EVOLUTIVOS DA FORMA RACEMOSA DA NEUROCISTICERCOSE}

\author{
Rodrigo Bazan \\ Orientador: Prof. Dr. Osvaldo Massaiti Takayanagui \\ Dissertação de Mestrado apresentada em 02/02/2010
}

Este estudo avaliou, de maneira retrospectiva, 36 pacientes portadores da forma racemosa da neurocisticercose. Foram analisadas as apresentações clínico-evolutivas incluindo líquido cefalorraquidiano (LCR), neuroimagem e tratamento. Dezesseis pacientes eram mulheres e 20 homens; 77,8\% moravam na zona urbana, a maioria com ensino fundamental. Associações de formas clínicas estiveram presentes em 94,4\% dos pacientes, hipertensão intracraniana, 75\%, meningite, 72,2\%, epilepsia, 61,1\%, cefaléia, 50\% e outras síndromes clínicas (cerebelares, vasculites, depressão e mielorradicuolopatia), 11,1\%. Das síndromes clínicas, houve predomínio de cefaléia no grupo feminino. Apresentaram na admissão, exame neurológico normal 38,9\%, alterações na fundoscopia 33,3\% e anormalidades em sistema motor e/ou tono $22,2 \%$. Evolutivamente, o exame neurológico foi normal em 55,6\% e anormal em 44,4\% (19,4\%, alterações cerebelares, $11,1 \%$, 
fundoscópicas). Houve 13,9\% de casos com a forma psiquiátrica da doença. Na análise do LCR, um paciente apresentou exame normal, em 26 pacientes evidenciou-se um padrão de meningite com predomínio linfocítico e em nove, o exame não foi realizado. Houve presença de eosinofilorraquia em $30 \%$ e o teste ELISA teve sensibilidade de $80 \%$. Na neuroimagem observaram-se lesões em cisternas do tronco encefálico em $86,1 \%$, cisternas da base 52,8\%, fissuras Silvianas $41,7 \%$, coróideas $25 \%$, inter-hemisférica $14 \%$, sulcos frontais 2,8\% e lesões em topografia extramedular em $11,1 \%$; $66,7 \%$ dos pacientes tiveram associações de topografias. Em 75\% dos pacientes houve associação com lesões intraparenquimatosas, com predomínio de lesões calcificadas e em 41,7\%, combinação com lesões ventriculares, principalmente no quarto ventrículo. Em $25 \%$ dos pacientes houve tratamento exclusivamente clínico, exclusivamente cirúrgico em 30,6\%, clínicocirúrgico em $36,1 \%$ e nenhum tratamento em $8,3 \%$. Receberam corticosteróide 77,8\% dos pacientes. Fizeram uso do albendazol como cisticida 95,4\% e dos que foram submetidos ao tratamento cirúrgico, em 23 pacientes houve interposição de derivação ventrículo peritoneal (95,8\%). Como principais complicações observaram-se: ventriculite (8,3\%), aracnoidite (30,6\%), infecção do cateter de derivação $(16,7 \%)$, córtico-dependência $(11,1 \%)$ e meningite bacteriana após procedimento cirúrgico (8,3\%). Evoluíram favoravelmente 33,3\% dos pacientes, desses, 66,7\% eram mulheres e 33,3\% homens. Tiveram desfecho considerado desfavorável 66,7\%; 11,11\% evoluíram para óbito (todos homens) e 55,6\% apresentaram melhora parcial ou sequela; desses, $60 \%$ eram homens. A causa dos óbitos foi atribuída à hipertensão intracraniana.

\title{
PERFIL HLA-DRB, ASPECTOS CLÍNICOS E RESSONÂNCIA MAGNÉTICA NUCLEAR EM PACIENTES BRASILEIROS COM ESCLEROSE MÚLTIPLA E NEUROMIELITE ÓPTICA
}

\section{Doralina Guimarães Brum Souza}

Orientador: Prof. Dr. Amilton Antunes Barreira

Tese de Doutorado apresentada em 19/02/2010

A neuromielite óptica (NMO) e a esclerose múltipla (EM) são doenças inflamatórias, autoimunes do sistema nervoso central (SNC), com sobreposição de características clínicas e outras, as quais têm levado NMO a ser considerada uma variante da EM. A NMO é mais frequente em não-brancos, enquanto a EM é mais prevalente em brancos. Recentemente, um anticorpo reativo contra aquaporina-4 (AQP4) (NMO-lgG), específico para NMO foi identificado, facilitando o diagnóstico diferencial com EM. No presente estudo, foram avaliados o perfil do HLA-DRB, os aspectos clínicos e de imagens em pacientes brasileiros com NMO ou EM, estratificados em grupos populacionais brancos ou mulatos, de acordo com a origem geográfica e étnica dos seus ancestrais. Foram avaliados 113 pacientes com EM (84 brancos, 29 mulatos), 27 com NMO soropositivo para NMO-lgG (NMO-lgG); e 114 doadores de sangue saudáveis (86 brancos e 28 mulatos). O grupo de alelos HLA-DRB1 *15 tem sido associado à EM nas diversas populações caucasianas, bem como em nossa série de pacientes com EM ( $\mathrm{p}=0,0155, \mathrm{OR} .=2,7)$. Comparado aos controles, o alelo HLA-ORB1 *1501 teve frequência aumentada em brancos com EM $(\mathrm{p}=0,0028, \mathrm{OR}=2,90)$, enquanto o alelo HLA-DRB1*01 teve frequência aumentada em pacientes mulatos $(\mathrm{p}=0,0024 ; \mathrm{OR}=4,28)$. O grupo de alelo HLAORB $1 * 03$ teve frequência aumentada em pacientes com NMO comparado com controles saudáveis ( $\mathrm{p}=0,0401 ; \mathrm{OR}=3,23)$. As comparações entre $\mathrm{NMO}$ e EM, nessa série, evidenciaram que o grupo de alelos HLA-DRB1 *15 estava aumentado na EM (OR=15,89; p<0,0001). O DRB3 apresentou-se aumentado na NMO $(\mathrm{p}=0,0064)$ e o DRBS na EM ( $\mathrm{p}=0,0009)$. O grupo de alelos HLAORB $1 * 15$ mostrou-se associado com a ausência de lesões extensas e centrais na RM da medula espinal. Em adição, o grupo de alelos HLA-ORB1 *15 foi associado com o preenchimento dos critérios de Barkhof. Esses resultados indicam que o perfil de HLA na NMO é diferente daqueles observados na EM, corroborando a distinção entre a NMO e a EM.

\section{EVOLUÇÃO CLÍNICA E FUNCIONAL APÓS HEMORRAGIA INTRAPARENQUIMATOSA CEREBRAL PRIMÁRIA: UM ESTUDO PROSPECTIVO BRASILEIRO}

\author{
Larissa Audi Teixeira da Silva \\ Orientador: Prof. Dr. João Pereira Leite \\ Dissertação de Mestrado apresentada em 19/02/2010
}

Acidente vascular cerebral (AVC) é a principal causa de morte e um grande problema de saúde pública no Brasil. A hemorragia intraparenquimatosa cerebral (HIC) é responsável por 10 a 15\% dos casos de AVC e está associada a uma alta mortalidade. Existem poucos estudos nacionais sobre epidemiologia, apresentação e evolução clínica de pacientes com HIC. A grande maioria dos dados sobre esta patologia é extrapolada de estudos realizados em países desenvolvidos, a despeito das disparidades étnicas e sócio-econômicas. Neste estudo, objetivamos traçar um perfil clínico e epidemiológico 
dos pacientes com HIC, acompanhar sua evolução e definir aspectos preditivos dessa evolução. Todos os pacientes adultos com HIC primária, admitidos no HCFMRP-USP entre janeiro de 2006 e dezembro de 2007 foram avaliados. A evolução dos pacientes foi acompanhada através da utilização de escalas clínicas de comprometimento neurológico na fase aguda e subaguda (Escala de coma de Glasgow-GCS, NIHSS) e escalas de incapacidade na fase subaguda e crônica (índice de Barthel e escala de Rankin modificada) aplicadas em 3, 6 e12 meses após o evento inicial. Os dados obtidos pela aplicação das escalas clínicas foram confrontados com os achados de neuroimagem colhidos na primeira semana após a admissão e com os exames laboratoriais. Foram admitidos 96 pacientes com HIC primária, sendo 63,5\% homens, idade média de $60,35 \pm$ 13,8 anos, após 11,5 \pm 14,5 horas em média do início dos sintomas. Á admissão os pacientes apresentaram NIHSS com mediana de 22 (IQ: 14 - 34); GCS com mediana de 11 (IQ: 6 - 14), volume da HIC média de 33,6 $\pm 33,2$ Ml, sendo que 63,5\% já apresentavam hemorragia intraventricular (IV) e 49\% hidrocefalia. Intubação orotraqueal foi necessária em 64,6\% dos pacientes e pneumonia ocorreu em 47,9\%. A mortalidade intrahospitalar (IH) foi de 40,6\%; 36,5\% em 30 dias; de 45,8\% até 3 meses; 52,1\% até 6 meses e 60,4\% até 1 ano. Após análise multivariada, os preditores de mortalidade foram glasgow à admissão $<8$, creatinina à admissão $\geq 1,2$, volume do hematoma $\geq 30$, hidrocefalia, origem infratentorial do hematoma e idade $\geq 50$. Os preditores de Rankin $\geq 5$ foram glasgow $<8$ à admissão, volume da HIC $\geq 30 \mathrm{~mL}$, hemorragia IV à admissão, hidrocefalia nos 4-5 primeiros dias e pneumonia. Os preditores de Barthel $<70$ a 3 meses foram NIHSS, volume da HIC $\geq 30$ $\mathrm{mL}$ e hidrocefalia à admissão e pneumonia. Os preditores de NIHSS $\geq 15$ foram volume da HIC $\geq 30$ mL e hidrocefalia à admissão. Estes achados demonstram uma elevada mortalidade da HIC no Brasil e sugerem que a os pacientes com HIC no país tem peculiaridades demográficas e de evolução neurológica que merecem ser consideradas e melhor exploradas.

\title{
ESTUDO MORFOMÉTRICO DO NERVO SURAL NA POLIRRADICULONEUROPATIA DESMIELINIZANTE INFLAMATÓRIA CRÔNICA IDIOPÁTICA
}

\author{
João Natel Polônio Machado \\ Orientador: Prof. Dr. Amilton Antunes Barreira \\ Tese de Doutorado apresentada em 01/03/2010
}

A síndrome da polirradiculoneuropatia desmielinizante inflamatória crônica é uma desordem adquirida do nervo periférico, usualmente responsiva ao tratamento. Avaliamos, retrospectivamente, dados clínicos, laboratoriais, eletrofisiológicos e biópsias do nervo sural de 38 pacientes com PDIC idiopática. Nossos objetivos foram a descrição dos achados morfométricos, a existência de possíveis grupos de anormalidades à morfometria e as possíveis correlações destas anormalidades com parâmetros clínicos, laboratoriais, eletrofisiológicos e resposta ao tratamento. O critério INCAT foi empregado para diagnostico. A medida de idade foi de 42,7 anos, predomínio do sexo masculino. A apresentação clínica mais frequente foi sensitivo motora, com fraqueza motora (95\%), hipo ou arreflexia (92\%), perda sensitiva de fibras grossas (79\%). O curso foi progressivo em $79 \%$ e recidivante em $21 \%$ dos casos. Grave incapacidade motora ocorreu em $65 \%$ dos casos. A eletroneuromiografia mostrou padrão desmielinizante em 47\%, desmielinizante e axonal em $45 \%$ e axonal em $8 \%$. Hiperproteinorraquia foi observada em $42 \%$. À microscopia de luz, 50\% das biópsias foram desmielinizantes, $45 \%$ desmielinizante e axonal e 5\% predominantemente axonal. Formação de bulbo de cebola ocorreu em $18 \%$, infiltrados celulares em $10 \%$ e edema endoneural em 5\%. Os pacientes com PDIC, apresentaram redução em $66 \%$ do número de fibras mielínicas e 55\% na densidade de fibras mielínicas. Identificamos três grupos de acordo com a razão g: desmielinizante, axonal e intermediário, com frequências de 50\%, 40\% e 10\%. As anormalidades histológicas qualitativas e morfométricas não se correlacionaram com os padrões eletrofisiológicos ou com as características clínicas ou resposta ao tratamento. No grupo desmielinizante na razão g apresentou diferença significativa relacionada à hiperproteinorraquia. A biópsia do nervo sural não tem valor preditivo para resposta ao tratamento e deve ser reservada nos casos suspeitos de PDIC, nos quais os estudos eletrofisiológicos e liquóricos são inconclusivos para o diagnóstico.

\section{VALIDAÇÃO DA VERSÃO BRASILEIRA DA ESCALA DE EQUILÍBRIO E MARCHA (GABS) E ANÁLISE DO RISCO DE QUEDAS DE INDIVÍDUOS COM DOENÇA DE PARKINSON E SUJEITOS SAUDÁVEIS}

\author{
Jussara Almeida de Oliveira \\ Orientador: Prof. Dr. Vitor Tumas \\ Dissertação de Mestrado apresentada em 02/03/2010
}

Os estudos realizados até o momento demonstram que os instrumentos descritos na literatura possuem pouca capacidade de identificar os indivíduos em risco de quedas e portanto, existe a necessidade do desenvolvimento de novos 
testes ou de uma bateria de testes para essa população. Este estudo teve como objetivo traduzir e validar a Escala de Equilíbrio e Marcha (GABS) para aplicação em pacientes com doença de Parkinson (DP), determinar as características clínicas que estariam associadas ao maior risco de quedas em pacientes com DP e sujeitos saudáveis e analisar a utilidade do teste de Estabilidade Postural para avaliar o risco de quedas nos pacientes com DP. Foram selecionados pacientes do Ambulatório de Distúrbios do Movimento (AEXP) do Hospital das Clínicas da Faculdade de Medicina de Ribeirão Preto - Universidade de São Paulo, com diagnóstico de DP e controles saudáveis. Os participantes foram avaliados por meio da versão motora simplificada da UPDRS, escalas de HY, SE, FOGQ, FES-I, BBS e GABS. Fizeram parte do estudo 107 pacientes com DP e 80 controles e pode-se verificar que a versão brasileira da GABS mostrou ser válida e confiável, com ótima consistência interna e boa confiabilidade inter e intraexaminador. Além disso, obteve validade convergente consistente, com correlações boas com outros instrumentos que avaliam o mesmo conceito. Somado a esses resultados, a GABS teve boa acurácia, sensibilidade, especificidade, valor preditivo positivo e valor positivo negativo considerável. Quando a GABS foi comparada com a BBS, as duas escalas tiveram resultados semelhantes. Entretanto, a GABS mostrou ser uma escala mais completa que a BBS, pois avalia diversos aspectos relacionados ao risco de quedas, como a instabilidade postural, alterações na marcha, o freezing e o medo de quedas, mostrando ser um instrumento mais interessante de ser utilizado em futuros ensaios clínicos e estudos prospectivos de evolução clínica da doença. Com relação às quedas, o principal ambiente relacionado às quedas nos pacientes com DP foi o doméstico e a marcha a principal causa, já nos controles o principal local das quedas também foi o doméstico e a principal causa de quedas foram os obstáculos presentes no ambiente. Além disso, maior tempo de doença e maior medo de quedas foram os fatores que mais contribuíram para explicar as quedas da população com DP. O teste de Estabilidade Postural conseguiu diferenciar os indivíduos com DP que sofreram quedas dos que não sofreram quedas, obteve correlações significativas com outros instrumentos que avaliam o equilíbrio e teve boa confiabilidade interexaminador.

\title{
Oftalmologia, Otorrinolaringologia e Cirurgia da Cabeça e Pescoço
}

\section{EFICIÊNCIA MASTIGATÓRIA NA DEFORMIDADE DENTOFACIAL}

\author{
Melissa Nara de Carvalho Picinato Pirola \\ Orientadora: Profa. Dra. Luciana V. Voi Trawitzki \\ Dissertação de Mestrado apresentada em 25/01/2010
}

A eficiência mastigatória pode ser quantificada pela capacidade individual de fragmentar alimentos naturais ou artificiais e pode estar prejudicada em indivíduos com deformidade dentofacial. O objetivo deste trabalho foi analisar a eficiência mastigatória em indivíduos com deformidades dentofacias, comparativamente a um grupo controle e verificar se o sexo, o índice de massa corpórea (IMC), a queixa de dificuldade para mastigar e o lado de preferência mastigatória referido influenciam na eficiência mastigatória. Participaram deste estudo 30 pacientes com deformidade dentofacial classe II (GD-II), 9 homens e 21 mulheres (média de 25 anos) e 35 pacientes com o diagnóstico de deformidade dentofacial classe III (GD-III), 18 homens e 17 mulheres (média de 24 anos); todos os pacientes com indicação para cirurgia ortognática. Também participaram 30 voluntários (GC), 12 homens e 18 mulheres (média de 24 anos), sem alterações na morfologia da face ou na oclusão dentária, sem ausências dentárias (à exceção dos terceiros molares) e sem sinais ou sintomas de disfunção na articulação temporomandibular (ATM). Foi aplicado um questionário com questões referentes a dificuldades para mastigar, lado de preferência mastigatória referido pelo participante, peso atual e altura também referidos pelo participante; e realizado um exame da cavidade oral. A eficiência mastigatória foi analisada pelo método colorimétrico com beads, assim, para cada cápsula mastigada, obteve-se um valor em concentração de fuccina (mg/ml). Cada indivíduo mastigou uma cápsula de beads por vez, durante 20 segundos cronometrados, num intervalo de 3 minutos entre cada mastigação, sendo duas cápsulas mastigadas habitualmente, uma do lado direito e uma do lado esquerdo, totalizando 4 cápsulas. As comparações dos valores de eficiência mastigatória em relação aos diferentes grupos, sexos, dificuldade para mastigar e ao lado de preferência mastigatória referido foram feitas por meio da análise de variância (ANOVA) considerando o nível de significância p<0,05; e o coeficiente de correlação de Pearson foi utilizado na comparação do IMC e a eficiência mastigatória, sendo que quanto mais próximo os valores estiverem de 1 ou -1, mais forte é a associação linear entre as variáveis. Verificou-se que a presença da deformidade dentofacial classe II e classe III influenciou a eficiência mastigatória quando comparada ao GC, mas não houve diferença entre GD-II e GD-III; o sexo influenciou a eficiência mastigatória apenas no GC, sendo que os homens apresentaram valores maiores de eficiência mastigatória do que as 
mulheres na mastigação habitual 2 e na mastigação unilateral à esquerda; o IMC e a queixa de dificuldade para mastigar relatada por alguns indivíduos não influenciaram a eficiência mastigatória em nenhum dos grupos e o lado preferencial da mastigação referido pelos indivíduos influenciou a eficiência mastigatória apenas no GC, sendo que os indivíduos que não relataram um lado de preferência mastigatória apresentaram maior eficiência mastigatória na mastigação habitual 2 e na mastigação unilateral à esquerda do que os indivíduos que relataram preferência por um lado de mastigação.

\title{
VALIDAÇÃO DE PROPOSTAS DE EDUCAÇÃO EM SAÚDE OCULAR COMUNITÁRIA APLICADAS A PROFISSIONAIS DE SAÚDE EM CENTROS DE ATENÇÃO PRIMÁRIA
}

\author{
Fabiano Cade Jorge \\ Orientador: Prof. Dr. Jayter Silva de Paula \\ Dissertação de Mestrado apresentada em 11/02/2010
}

O objetivo do presente estudo foi o de avaliar a atuação do oftalmologista como modificador das práticas da saúde ocular, através da comparação da qualidade das fichas de referências provenientes de centros primários de saúde antes e após um programa de treinamento em oftalmologia (PTO), e o impacto deste processo educacional nos profissionais da atenção básica de saúde.

Foi realizado, retrospectivamente, o estudo de prontuários médicos de pacientes referenciados para um serviço público de oftalmologia, em Ribeirão Preto, região Sudeste do Brasil. A amostra foi composta por fichas de referências de pacientes provenientes de atendimentos em quatro Núcleos do Programa Saúde da Família (NSF) em dois momentos de estudo, antes (M1 - fevereiro e março/ 2007) e depois do PTO (M2 - outubro e novembro/ 2007), e por outros pacientes advindos, no mesmo período, de quatro Unidades Básicas de Saúde (UBS) que não receberam o PTO. A hipótese diagnóstica dos encaminhamentos foi comparada com os diagnósticos estabelecidos no centro de referência pelo especialista e foram avaliados os principais diagnósticos referenciados. A avaliação do impacto do processo educacional deu-se complementarmente por meio de um questionário básico aplicado aos agentes comunitários de saúde, antes e após o PTO.

Duzentos e quarenta e seis casos foram estudados, 53 provenientes dos NSF e 193 de outras UBS. Após o PTO, o número de referências advindas dos NSF foi significativamente menor que antes do PTO (8/138 e 45/108, respectivamente; $\mathrm{P}<0.0001$ - teste exato de Fisher). As taxas de concordância (kappa) dos diagnósticos dos NSF, quando comparados com os firmados pelo oftalmologista, foram maiores que os das UBS nos dois momentos do estudo, porém nenhuma comparação mostrou significância estatística (0,47 e 0,25 em M1 e 0,50 e 0,37 em M2, para NSF e UBS, respectivamente). Na análise comparativa, não se observaram diferenças significantes com relação às respostas dos agentes comunitários de saúde, entre $\mathrm{M} 1$ e $\mathrm{M} 2(\mathrm{P}=0,586$, teste t pareado).

Apesar de os níveis de concordância não apresentarem diferenças significantes, observou-se uma tendência de maior número de acerto diagnóstico nas fichas de referência advindas dos centros submetidos a seis meses do PTO. Além disso, o PTO pode estar relacionado com o menor número de encaminhamentos pelos NSF em estudo, provavelmente devido à melhor condução local dos problemas oculares.

\section{INFLUÊNCIA DO ENVELHECIMENTO SOBRE OS MECANISMOS SECRETÓRIOS E ANTI-OXIDANTES DA GLÂNDULA LACRIMAL}

Lilian Midori Tomiyoshi

Orientador: Prof. Dr. Eduardo Melani Rocha

Dissertação de Mestrado apresentada em 03/03/2010

O envelhecimento é responsável por alterações funcionais e estruturais na glândula lacrimal, incluindo o acúmulo de radicais livres, levando a danos em proteínas, lipídios e DNA em vários tecidos. O objetivo do presente estudo é avaliar o efeito do envelhecimento na estrutura e nos mecanismos secretórios da glândula lacrimal, entre eles a expressão de proteínas das famílias Rab e SNARE, e elementos relacionados a mecanismos anti-oxidantes. Foram utilizados 10 ratos Wistar machos de 24 meses e 10 ratos Wistar machos de 02 meses. Foi comparada a secreção lacrimal e citologia de impressão da córnea. As glândulas lacrimais foram retiradas e submetidas à comparação esturural e morfológica, à análise da expressão de peroxidase, vitamina E e MDA. A análise da expressão de proteínas da família Rab e SNARE foi realizada por RT-PCR. No grupo de ratos velhos, houve aumento do peso do animal $(\mathrm{p}=0,043)$ e do peso da glâdula lacrimal $(\mathrm{p}=0,0079)$, porém quando ajustados para proporção (peso da glândula/peso do animal) não houve diferença estatística $(\mathrm{p}=0,2222)$. A citologia de impressão demonstrou maior metaplasia na córnea dos velhos $(\mathrm{p}=0,0320)$. Em relação aos marcadores de estresse oxidativo, houve aumento de MDA ( $\mathrm{p}=0,0571)$ e diminuição de vitamina $\mathrm{E}(\mathrm{p}=0,0159)$ na glândula 
lacrimal dos velhos. A expressão do RNAm de Rab 27b e Rab $3 b$ foi confirmada nesse tecido e estão diminuídas com o envelhecimento $(\mathrm{p}<0,05)$, mas não há diferença na expressão gênica da Vamp. Mecanismos secretórios e anti-oxidantes alterados pelo envelhecimento demonstrados nesse estudo podem ajudar a explicar distúrbios lacrimais e da superfície ocular. Essas informações podem ajudar a propor novas medidas terapêuticas para o olho seco relacionado à senilidade.

\title{
ESTUDO DA RELAÇÃO ESCAVAÇÃO/DISCO EM ADOLESCENTES
}

\author{
Maria Elizabete Jimenes de Campos \\ Orientadora: Profa. Dra. Maria de Lourdes Veronese Rodrigues \\ Dissertação de Mestrado apresentada em 15/03/2010
}

Objetivos: Determinar as razões escavação/disco e verificar a porcentagem de assimetrias entre os dois olhos em uma população de adolescentes de uma cidade do Estado de São Paulo, região sudeste do Brasil. Verificar eventual influência de vícios de refração sobre essas razões escavação/disco. Método: Retinografias de ambos os olhos de 123 jovens foram digitalizadas na resolução de 300 Pixels por polegada (300dpi), 8 bits, padrão de cor RGB. Para a realização das medidas dos parâmetros verticais do disco óptico foi utilizado o software Image J, versão 1.42, desenvolvido pelo National Institute of Health $(\mathrm{NIH})$, plataforma Java versão 1.6. As medidas de refração foram realizadas no Auto-kerato-refractometer KR 7000, Topcon, California, USA, sendo utilizados os equivalentes esféricos. Resultados: As médias das medidas da relação escavação/disco óptico foram de 0,343 \pm 0,110 (mediana 0,340) para o olho direito e 0,339 \pm 0,098 (mediana 0,340) para o olho esquerdo. Os valores das diferenças entre as medidas da relação escavação/disco óptico, entre os dois olhos de um mesmo indivíduo, variaram de 0 a 0,3. Conclusões: As razões escavação/disco óptico e a frequência de assimetrias em adolescentes são similares às descritas para a população adulta ocidental.

\section{Ortopedia, Traumatologia e Reabilitação}

\section{ASSOCIAÇÃO ENTRE POSTURA E PARÂMETROS FUNCIONAIS DOS SISTEMAS, ESTOMATOGNÁTICO, CERVICAL E PULMONAR EM CRIANÇAS ASMÁTICAS E NÃO ASMÁTICAS}

\author{
Thaís Cristina Chaves \\ Orientadora: Profa. Dra. Débora Bevilacqua Grossi \\ Tese de Doutorado apresentada em em 09/02/2010
}

Introdução: Nas crianças asmáticas o desenvolvimento da hiperinsuflação pulmonar e overuse da musculatura cervical inspiratória, bem como a respiração bucal, podem estar associadas ao desenvolvimento de alterações da postura corporal. Além disso, especificamente a respiração bucal pode estar associada ao aparecimento de alterações na função mastigatória e Disfunção Têmporo-mandibular (DTM), bem como a alterações da postura crânio-cervical e consequente Disfunção da Coluna Cervical (DCC). E a literatura demonstra a existência de associação entre essas disfunções em indivíduos adultos não asmáticos e não respiradoras bucais. Objetivo: O objetivo deste estudo foi avaliar os fatores envolvidos no desenvolvimento da DTM, DCC e das alterações da postura corporal e crânio-cervical em crianças asmáticas respiradoras bucais quando comparadas a não asmáticas respiradoras nasais, bem com verificar a associação entre

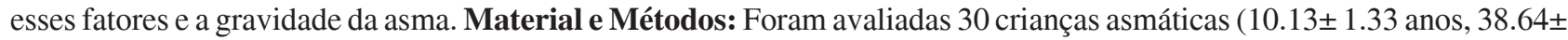
$9.99 \mathrm{~kg}$ e $1.42 \pm 0.09 \mathrm{~m})$ e 30 crianças não asmáticas $(10.28 \pm 1.14$ anos, $38.76 \pm 7.16 \mathrm{~kg}$ e $1.43 \pm 0.08 \mathrm{~m})$. Das 30 crianças asmáticas, 15 apresentaram asma leve persistente e 15 asma moderada em concordância com os critérios da GINA (2004). Os pacientes foram submetidos às seguintes avaliações: avaliações através dos índices de Fonseca et al. (1994) e da aplicação do Eixo I do RDC/TMD para DTM, através do índice de Wallace \& Klineberg (1993) para avaliação da DCC, Limiar de dor por pressão (LDP) dos músculos mastigatórios e cervicais, avaliação da postura corporal por Fotogrametria, Morfologia crânio-facial e Postura crânio-cervical através de radiografias e a atividade elétrica durante atividades mastigatórias. Análise Estatística: Os dados foram analisados através do teste-t de student, teste de qui-quadrado, Coeficiente de Correlação Intraclasse (ICC) e Correlação de Spearman (p<0.05). Resultados: Mais de 43.33\% das crianças asmáticas foram classificadas em alguma categoria do eixo I do RDC/TMD em relação a 16\% dos não asmáticos. A intensidade dolorosa à palpação dos músculos mastigatórios mostrou-se significativamente maior nos asmáticos quando comparados aos controles para a maior parte das estruturas mastigatórias consideradas e também foram verificados 


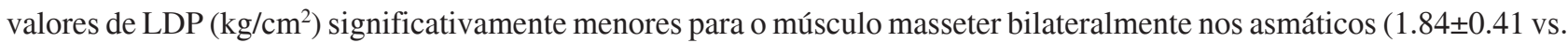
$2.06 \pm 0.45$ e $1.65 \pm 0.35$ vs. $1.86 \pm 0.42)$. Não foram verificadas diferenças entre os grupos com relação aos sinais e sintomas de DCC. Na análise da postura corporal não foram observadas diferenças significativas entre os grupos de asmáticos e não asmáticos e não foi verificada influência da gravidade da asma. Com relação à morfologia crânio-facial foram observados valores médios significativamente maiores no grupo de crianças asmáticas para vários ângulos de posicionamento da mandíbula e maxila (NSL/ML: $34.59 \pm 6.21$ vs. 30.71 \pm 5.87 ; NSL/NL: $6.63 \pm 5.02$ vs. $4.30 \pm 3.38$; ML/RL: $129.14 \pm 4.92$ vs. $125.38 \pm 5.50$;

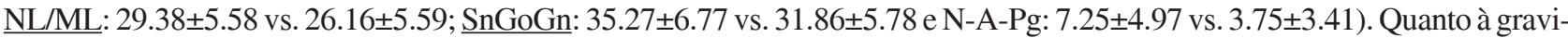
dade da asma foi verificado ângulo de inclinação dos incisivos superiores significativamente maior nos asmáticos moderados e ângulo de convexidade de face (N-A-Pg) (ILs/NL: $117.22 \pm 5.96$ vs. $112.30 \pm 5.55$; N-A-Pg: $5.53 \pm 3.34$ vs. 9.23 \pm 5.89 ) e frequência significativamente maior de classe II e III esquelética nesse grupo. Para a postura crânio-cervical foi observado ângulo crânio-vertebral (CVA) significativamente menor nos asmáticos em relação aos não asmáticos (106.38ะ7.66 vs. 111.21 7.40 ) e frequência significativamente maior de crianças asmáticas com alterações no posicionamento do hióideo em relação às não asmáticas (36\% vs. $7 \%$ ). Também foram observados valores significativamente maiores nos asmáticos moderados em relação aos asmáticos leves para os ângulos de inclinação da cervical superior em relação à horizontal. Durante os testes de eletromiografia de superfície de músculos mastigatórios não foram verificadas diferenças significativas entre os grupos e nos grupos divididos quanto à gravidade da asma. Foram observadas correlações leves e moderadas no grupo de crianças asmáticas para as seguintes variáveis: (1) ângulos de postura da cabeça, morfologia crânio-facial e variáveis de função pulmonar; (2) níveis de atividade elétrica, ângulos de postura crânio-cervical e sinais e sintomas de DTM e (3) ângulos de morfologia crânio-facial e valores de LDP de músculos mastigatórios e cervicais. Conclusão: Esses resultados demonstraram que a asma está associada ao desenvolvimento de DTM, mas não de DCC. Os asmáticos também demonstraram alterações em extensão da cabeça e cervical alta, maior inclinação do plano maxilar e mandibular, aumento da convexidade da face, sugerindo um padrão de face alongada, bem como maior frequência de alterações oclusais dentárias em relação à maior gravidade da asma.

\title{
PROPOSTA DE AVALIAÇÃo E INTERVENÇÃo ATRAVÉS DA PREVENÇÃo DE INCAPACIDADE EM PACIENTES COM HANSENÍASE
}

\author{
Fernanda Carvalho Batista Rodini
}

Orientadora: Profa. Dra. Marisa de Cássia Registro Fonseca

Dissertação de Mestrado apresentada em 19/02/2010

A hanseníase é uma doença infectocontagiosa, de evolução lenta, que se manifesta principalmente através de sinais e sintomas dermatoneurológicos, com lesões na pele e nos nervos periféricos, principalmente nos olhos, mãos e pés. O objetivo deste estudo foi elaborar um manual de orientação visando à prevenção de incapacidade nos olhos, mãos e pés dos pacientes com hanseníase e avaliar sua eficácia em relação ao aparecimento e evolução das deficiências sensitivo-motoras, incapacidade e qualidade de vida desses pacientes. Foram comparadas as avaliações fisioterapêuticas inicial e após 12 meses de tratamento de uma amostra de 26 pacientes com diagnóstico recente de hanseníase atendidos no HCFMRP-USP entre 2007 e 2008. Foram utilizados métodos de avaliação qualitativa e quantitativa. A análise estatística foi realizada pelos modelos lineares de efeitos mistos através do software SAS versão 9 e o teste exato de Fisher. Os nervos mais acometidos foram o ulnar e tibial posterior. Houve melhora significativa nos domínios Dor e Aspectos Sociais do Questionário SF-36. Na amostra estudada, apesar das medidas preventivas aplicadas, as deformidades e o grau de incapacidade permaneceram, porém houve melhora no ressecamento da pele e da função muscular das mãos e dos pés. O manual de orientações mostrou ser uma ferramenta importante no tratamento dos pacientes com hanseníase, pois a informação sobre a doença permitiu que esses pacientes participassem ativamente do tratamento e no combate ao estigma da doença.

\section{ANÁLISE FUNCIONAL DA MARCHA APÓS A APLICAÇÃO DO ULTRASSOM TERAPÊUTICO NA MEDULA ESPINHAL ASSOCIADO AO EXERCÍCIO FÍSICO - ESTUDO EXPERIMENTAL EM RATOS SUBMETIDOS A LESÃO NERVOSA}

Fernanda Guadallini Jatte

Orientador: Prof. Dr. Nilton Mazzer

Dissertação de Mestrado apresentada em 19/02/2010

Um estudo sobre a influência da natação e do ultrassom terapêutico aplicado na medula espinhal, na inserção da raiz dorsal do nervo ciático de ratos, submetidos a lesão por esmagamento controlado e avaliado por meio de vídeo- 
filmagem foi realizado. Quarenta ratos Wistar machos foram utilizados e divididos em quatro grupos de dez animais, de acordo com o estímulo aplicado. O nervo ciático direito dos animais foi exposto sob anestesia geral e por uma incisão cutânea longitudinal na face lateral da coxa, foi esmagado utilizando um dispositivo de peso morto em um segmento logo acima da bifurcação durante 10 minutos, com carga estática de 5000g. Os animais foram divididos em quatro grupos de acordo com o tratamento pós-operatório: Grupo I - sham, irradiação simulada; Grupo II - ultrassom, irradiação efetiva; Grupo III - natação; Grupo IV - ultrassom + natação. A irradiação ultrassônica foi de baixa intensidade (intensidade de 0.16 W/cm²; frequência de $1 \mathrm{MHz}$; duração de 1 minuto). A natação teve duração de sessenta minutos cada sessão. Os estímulos foram iniciados no $7^{\circ}$ dia pós-operatório e aplicados diariamente por 6 semanas, totalizando 42 dias. As impressões das pegadas dos animais foram realizadas na fase pré-operatória e da $1^{\mathrm{a}}$ até a $7^{\mathrm{a}}$ semana de estímulo. Foram capturadas por vídeo-filmagem e avaliadas através do Índice Funcional do Ciático (IFC) pelo programa Análise Funcional dos Nervos Periféricos - AFNP. Os resultados foram submetidos à análise estatística e mostraram que nas condições deste trabalho, a aplicação do ultrassom terapêutico sobre a medula espinhal e suas raízes acelerou o processo de regeneração do nervo ciático. Já o exercício físico não demonstrou resultados satisfatórios, porém, quando associado ao ultrassom, apresentou resultados funcionais visíveis.

\title{
TRADUÇÃO, ADAPTAÇÃO CULTURAL E VALIDAÇÃO DO QUESTIONÁRIO SHOULDER PAIN AND DISABILITY INDEX (SPADI) PARA LÍNGUA PORTUGUESA: SPADI-BRASIL
}

\author{
Jaqueline Martins
}

Orientadora: Profa. Dra. Anamaria Siriani de Oliveira

Dissertação de Mestrado apresentada em 22/02/2010

O objetivo desse estudo foi realizar a tradução e adaptação cultural do questionário SPADI para a Língua Portuguesa do Brasil e avaliar sua confiabilidade e validade. Para tanto, duas fases foram desenvolvidas. A primeira fase consistiu na tradução e adaptação cultural do SPADI para Língua Portuguesa do Brasil, enquanto que a segunda fase testou sua confiabilidade e validade. Noventa indivíduos participaram da primeira fase e quarenta e nove participaram da segunda, todos caracterizados pela presença de disfunção no ombro, faixa etária acima de 18 anos e nível educacional e sociocultural variado. O processo de tradução e adaptação cultural se baseou em um protocolo internacionalmente aceito e consistiu de seis estágios: tradução, síntese, retro-tradução, revisão pelo Comitê, pré-teste e avaliação dos documentos pelo Comitê e pelo autor da versão original do SPADI. O estudo foi autorizado pelo autor do SPADI, que manteve contato constante com os pesquisadores. Durante a fase de adaptação cultural, os itens não compreendidos por $20 \%$ ou mais dos pacientes foram reformulados de forma a manter equivalência com a versão original, sendo reaplicados até que valores menores que $20 \%$ fossem alcançados. Os testes de confiabilidade e validade foram realizados através de duas entrevistas, separadas por um intervalo de tempo de 2 a 7 dias. Na primeira entrevista, foram aplicados os questionários SPADI-Brasil, Disabilities of Arm, Shoulder and Hand (DASH), domínios de dor, função física e saúde mental do Short Form-36 (SF-36) e a escala de satisfação, enquanto que na segunda entrevista o SPADI-Brasil foi reaplicado juntamente com uma Escala de Avaliação Global que identificou os pacientes estáveis para a condição de disfunção. A versão brasileira do SPADI foi testada para validade de conteúdo através dos efeitos mínimo e máximo e para validade de constructo convergente e discriminante através do Coeficiente de Correlação de Pearson estabelecido para as comparações entre os instrumentos e pela construção de três hipóteses. A confiabilidade testereteste foi analisada pelo Coeficiente de Correlação Intraclasse (ICC) e a consistência interna pelo Alpha de Cronbach. Os resultados desse estudo revelaram a necessidade de três repetições do pré-teste. Na primeira e segunda aplicação, o SPADI foi auto-administrado e na terceira aplicação a versão brasileira do SPADI (SPADI-Brasil) foi obtida na forma de entrevista, com a elaboração de um material de instruções para orientar o examinador. A confiabilidade teste-reteste foi excelente, variando de 0.90 a 0.94 e a consistência interna foi positiva, variando de 0.87 a 0.89 . Correlação de forte a moderada foi observada para as comparações entre o SPADI-Brasil, o DASH e os domínios de dor e de função física do SF-36, com correlação mais fraca entre o SPADI e o domínio de saúde mental do SF-36. As hipóteses foram confirmadas para validade tanto convergente quanto discriminante. Este estudo conclui que a versão brasileira do SPADI se mostrou um instrumento confiável e válido para avaliação da dor e da incapacidade de pacientes com disfunção de ombro. 


\title{
ANÁLISE DA CONFIABILIDADE DE UM MÉTODO SEMIAUTOMÁTICO ASSISTIDO POR COMPUTADOR NA DETERMINAÇÃO DE PARÂMETROS RELACIONADOS A ESCOLIOSE IDIOPÁTICA
}

\author{
Michele Carneiro Tanure \\ Orientadora: Profa. Dra. Anamaria Siriani de Oliveira \\ Dissertação de Mestrado apresentada em 23/02/2010
}

\begin{abstract}
O objetivo desse estudo foi avaliar a confiabilidade das mensurações digitais da rotação axial vertebral e do desvio lateral da coluna no plano frontal a partir de radiografias digitalizadas, utilizando um novo método digital, capaz de reproduzir de forma semiautomática as técnicas de Perdriolle e Raimondi para o cálculo da rotação e o ângulo de Cobb para o desvio lateral da coluna. Para isso, foram analisadas 26 radiografias das vértebras T3 e L4 rodadas previamente com medidas conhecidas e 44 radiografias panorâmicas de pacientes com escoliose idiopática selecionados no ambulatório de coluna do Hospital das Clínicas de Ribeirão Preto. Durante a pesquisa, três médicos ortopedistas, cirurgiões da coluna estimaram a rotação e o desvio lateral da coluna usando o método digital e o método manual tradicional. Para analisar a confiabilidade do método digital, foi calculado a acurácia (grau de veracidade) e precisão (grau de reprodutibilidade) das medições realizadas pelos avaliadores através do Erro médio quadrático $(R M S)$ e seu desvio padrão (DP). Também foi calculado o coeficiente de correlação intraclasse (ICC) das medidas e o intervalo de confiança a 95\% (IC) do ICC. Os resultados mostraram que, na análise da rotação, o método digital tem um erro $43 \%$ menor do que o manual e uma correlação mais forte. Para a análise do ângulo de Cobb, podemos observar que os métodos manual e digital não apresentaram diferenças estatisticamente significativas $(t=0.51>0.05)$ o que nos garante que o método digital é válido para a função do cálculo do ângulo de Cobb. Além desses valores, o método digital apresentou vantagens como menor tempo para o cálculo, fácil acesso para comparações e acompanhamento, menor risco de perda de radiografias, além de permitir ao usuário mensurar a curvatura com maior nitidez de imagem, com grande resolução e zoom. A técnica digital pode ser facilmente aplicável a prática clínica e ainda possibilitar a criação de um banco de dados com precisão, estendendo seu uso para estudos longitudinais. Em consequência disto, podemos concluir que o método digital foi capaz de incrementar a acurácia e precisão das medidas de rotação vertebral e desvio lateral da coluna, mostrando-se confiável.
\end{abstract}

\section{FREQUÊNCIA E SEVERIDADE DA DISFUNÇÃO TEMPOROMANDIBULAR (DTM) EM MULHERES COM MIGRÂNEA E MIGRÂNEA CRÔNICA}

\author{
Maria Cláudia Gonçalves \\ Orientadora: Profa. Dra. Débora Bevilacqua Grossi \\ Dissertação de Mestrado apresentada em 26/02/2010
}

A Migrânea e a Disfunção Temporomandibular (DTM) são doenças crônicas e tem como aspecto mais importante a dor crônica. Muitos trabalhos descrevem sinais e sintomas de DTM em pacientes com cefaleia sugerindo uma associação entre essas duas condições. Porém, ainda são poucos os trabalhos que utilizaram um critério que fornecesse não apenas sinais e sintomas, mas também a classificação diagnóstica. Assim, o objetivo deste trabalho foi avaliar a frequência da DTM a partir da aplicação do RDC/TMD e a severidade da DTM através do Índice Anamnésico de Fonseca em mulheres com Migrânea, Migrânea Crônica e mulheres sem queixa de cefaleia. Participaram deste estudo 91 mulheres, divididas em três grupos: 30 mulheres no Grupo Controle (GC), 38 mulheres no Grupo Migrânea (GM) e 23 mulheres no Grupo Migrânea Crônica (GMC). As voluntárias dos grupos GM e GMC foram selecionadas durante a primeira consulta no Ambulatório de Cefaleia (ACEF) do Hospital das Clínicas de Ribeirão Preto da Faculdade de Medicina da Universidade de São Paulo e as do GC entre as acompanhantes dos pacientes naquele mesmo dia. Foram inclusas voluntárias com idade entre 18 e 55 anos, que não tivessem ingerido antiinflamatórios e/ou analgésicos nas últimas 24 horas antecedentes à avaliação fisioterapêutica, que não tivesse história de trauma na face, nem usasse prótese dentária parcial ou total e foram excluídas voluntárias com outros tipos de cefaleia e doenças sistêmicas como fibromialgia e artrite reumatóide. Para o GC, as voluntárias não podiam ter queixa de cefaleia nos últimos 3 meses. Três examinadores participaram da coleta. Para análise dos dados foi utilizado a análise da variância (ANOVA two-Way $\mathrm{p}<0,05$ ) na comparação dos dados antropométricos e da amplitude de movimento mandibular entre os três grupos e Tukey como post-hoc análise para avaliar a diferença no número de locais dolorosos e o número de diagnósticos, com nível de significância de $(\mathrm{p}<0,05)$. O teste qui-quadrado foi utilizado para verificar a diferença de diagnóstico entre os três grupos e para verificar a frequência da severidade entre os três grupos foi utilizado o teste exato de Fisher. As voluntárias dos grupos com migrânea apresentaram maior frequência de diagnósticos de DTM em comparação ao GC, p $<0,05$ e não foi observada diferença entre os grupos com migrânea. Os diagnósticos, segundo o RDC/TMD, do grupo I (dor miofascial) foram os mais prevalentes nos três grupos estudados e 
foi mais frequente nos grupos com migrânea. Os diagnósticos dos grupos I+III estiveram presentes nos três grupos estudados e com maior frequência no grupo GM. Não foram encontrados diagnósticos individuais pertencentes apenas aos grupos II e III. O número de pontos dolorosos musculares foi significativamente maior nos grupos GM e GMC em relação ao controle e não houve diferença entre os grupos com GM e GMC. As voluntárias dos grupos com migrânea apresentaram maiores graus de severidade de DTM, em comparação ao GC, p<0,05 e o GMC apresentou maior severidade que o GM. Os resultados deste trabalho demonstraram que Mulheres com Migrânea tem maior frequência de DTM, apresentam maior número de diagnósticos e de pontos dolorosos segundo o RDC/TMD que mulheres sem migrânea bem como maiores graus de severidade de DTM. Portanto a DTM e a Migrânea estão clinicamente relacionadas.

\title{
AVALIAÇÃO DO EFEITO DO CETOROLACO E DA MORFINA NA DOR AGUDA PÓS-OPERATÓRIA EM PACIENTES SUBMETIDAS Á ANESTESIA SUBRACNÓIDE COM BUPIVACAÍNA HIPERBÁRICA
}

\author{
Cláudia Cristiane Feracini Righeti \\ Orientadora: Profa. Dra. Gabriela Rocha Lauretti \\ Dissertação de Mestrado apresentada em 31/03/2010
}

Introdução: Pacientes submetidos a artroplastia total do joelho frequentemente queixam-se de dor de forte intensidade durante o período pós-operatório imediato beneficiando-se da associação de morfina por via espinal, onde tanto a analgesia quanto os efeitos adversos são dependentes da dose. O objetivo deste estudo foi avaliar o efeito antinociceptivo de morfina e do cetorolaco administrados por via espinal, de forma isolada ou combinada, em pacientes submetidos a artroplastia total de joelho.

Métodos: Após aprovação do Comitê de Ética em Pesquisa e consentimento formal, 80 pacientes submetidos à artroplastia total do joelho sob anestesia subaracnóide com bupivacaina hiperbárica foram divididos de forma prospectiva, aleatória e duplamente encoberta em 4 grupos. O grupo Controle recebeu solução fisiológica (2 ml) como droga teste espinal. O grupo Morfina (GM) recebeu 200 g de morfina, o grupo Cetorolaco (GK) recebeu 2 mg de cetorolaco como droga teste espinal, e finalmente o grupo Morfina-Cetorolaco (GMK) recebeu $200 \mathrm{~g}$ morfina $+2 \mathrm{mg}$ cetorolaco. Analgesia e efeitos adversos foram avaliados. $\mathrm{P}<0,05$ foi considerado significante.

Resultados: Os grupos foram demograficamente semelhantes entre si. Em relação ao tempo de requisição do primeiro analgésico o GM foi semelhante ao GK e maior quando comparados ao GC (p<0,01). O GMK apresentou o maior tempo de analgesia comparado aos demais grupos ( $\mathrm{p}<0,001)$. O consumo de analgésicos foi: $\mathrm{GC}>\mathrm{GM}=\mathrm{GK}(\mathrm{p}<0,05)$. $>\mathrm{GMK}$ $(\mathrm{p}<0,01)$.

Conclusões: A administração de $200 \mathrm{~g}$ de morfina espinal associada a $2 \mathrm{mg}$ de cetorolaco espinal resultou em efeito analgésico superior em relação ao tempo de requisição do primeiro analgésico e consumo total de analgésicos, comparado com as drogas administradas de forma isolada, sem contudo resultar em aumento da incidência de efeitos adversos.

\section{Patologia}

\section{OS EFEITOS DOS FÁRMACOS LISINOPRIL E LOSARTAN SOBRE A PANCREATITE OBSTRUTIVA EM RATOS}

\author{
Roberto de Barros Silva \\ Orientadora: Profa. Dra. Leandra Náira Zambelli Ramalho \\ Dissertação de Mestrado apresentada em 26/01/2010
}

A pancreatite aguda é uma doença inflamatória do pâncreas, que leva a uma série de efeitos deletérios aos órgãos adjacentes do pâncreas. No Brasil, a incidência desta disfunção é de 15,9 casos por 100.000 habitantes. A mortalidade ocupa $25 \%$ quando há necrose pancreática, sendo que 50\% dos óbitos ocorrem na fase precoce, ou seja, nos primeiros 14 dias devido a Síndrome da Resposta Inflamatória Sistêmica (SRIS). A etiologia da pancreatite aguda tem sido considerada multifatorial; com isso eventos patológicos discretos contribuem para a iniciação e a perpetuação desta disfunção. Muitos estudos têm mostrado uma íntima relação entre o Sistema Renina - Angiotensina - Aldosterona na causa e perpetuação da pancreatite aguda. Em modelos obstrutivo de pancreatite esta relação permanece obscura. O objetivo desse estudo é 
mostrar os efeitos de dois fármacos anti-hipertensivos (lisinopril e losartan) sobre esses modelos obstrutivos de pancreatite. Foi-se feito imunoistoquímica para células estreladas pancreáticas em ratos Wistar, que foram divididos em três grupos e foi-se feito Hematoxilina e Eosina juntamente com Sírius Red, para ver infiltrado inflamatório e deposição de colágeno respectivamente. Nosso trabalho mostrou que os animais tratados tanto com lisinopril quanto com Losartan tiveram uma depleção significativa na formação de fibrose pancreática em modelo experimental obstrutivo de pancreatite aguda.

\title{
ÚLCERAS ESOFÁGICAS EM PORTADORES DO VÍRUS DA IMUNODEFICIÊNCIA HUMANA: ETIOLOGIA E ANÁLISE COMPARATIVA ENTRE MÉTODOS DIAGNÓSTICOS
}

\author{
Mariângela Ottoboni Brunaldi \\ Orientador: Prof.Dr. Sérgio Zucoloto \\ Dissertação de Mestrado apresentada em 19/02/2010
}

As infecções virais são as maiores responsáveis pelas úlceras esofágicas no portador do HIV, sendo o Citomegalovírus (CMV) o agente mais observado, seguido pelo Herpes Vírus Simples (HSV). A abordagem clínica adequada e a utilização de métodos diagnósticos precisos são de grande relevância para o estabelecimento etiológico. Os objetivos deste trabalho foram: avaliar a prevalência de úlceras esofágicas em portadores do HIV; pesquisar os agentes etiológicos associados; verificar a acurácia dos métodos diagnósticos comparando as impressões obtidas pela endoscopia digestiva alta (EDA), histologia utilizando o método de Hematoxilina-Eosina (H\&E) e Imuno-histoquímica (IH) para pesquisa de CMV e HSV; avaliar o impacto da coloração para fungos (Gomori metenamina prata- GMS) e bacilos álcool-ácidos resistentes [BAAR- Ziehl-Neelsen (ZN)] e a relevância numérica da amostragem tecidual na avaliação etiológica. Trata-se de um estudo descritivo, retrospectivo, do tipo transversal, baseado em levantamento de dados demográficos, clínicolaboratoriais, endoscópicos obtidos por revisão de prontuários e análise histológica às cegas de biópsias endoscópicas (H\&E, IH, GMS e ZN) de úlceras esofágicas em 41 portadores do HIV, no período de agosto de 2002 a setembro de 2006 . A IH foi considerada método padrão. No período avaliado, 399 portadores do HIV submeteram-se à EDA, detectando-se úlcera esofágica em 41 pacientes (23 homens, 25 a 56 anos) com uma prevalência de 10,27\%. A mediana da contagem de CD4 foi 49 céls/mm3 e da carga viral 58869,5 cópias/ml. A EDA revelou 29/41úlceras esofágicas suspeitas de infecção pelo CMV; 7/41 pelo HSV; 2/41 relacionada ao refluxo gastroesofágico (DRGE); 1/41 por monilíase; 1/41 por paracoccidioidomicose (PCM) e 1/41 inespecífica. O H\&E detectou: 25/41 úlceras com aspectos inflamatórios inespecíficos (61\%); 6/41 associadas à monilíase (16\%); 4/41 por infecção pelo CMV (10\%); 2/41 HSV (5\%); 1/41CMV e HSV (2\%); 1/41 por PCM (2\%); 1/41 devido a Histoplasmose (2\%) e 1/41 infiltração neoplásica por Linfoma não Hodgkin (2\%). A IH para CMV e HSV confirmou os achados do H\&E e detectou mais um caso. A EDA revelou sensibilidade alta (100\%) para a detecção da úlcera esofágica, especificidade baixa para a caracterização etiológica viral (15\%) quando comparada ao H\&E e a IH. O H\&E mostrou-se um método adequado para avaliação etiológica com sensibilidade de $87 \%$ e especificidade de $100 \%$ quando comparada a IH. A pesquisa de BAAR pelo ZN foi negativa nas 34 amostras realizadas. O GMS confirmou a presença de fungos detectados ao H\&E e foi fundamental na caracterização morfológica do Histoplasma capsulatum e do Paraccocidioides brasiliensis. O número de amostras não influenciou na avaliação etiológica final. Os nossos achados recomendam o H\&E como método adequado na avaliação etiológica de úlceras esofágicas no portador do HIV e indicam a IH para pesquisa viral somente nos casos suspeitos, porém, não típicos ao H\&E.

\section{Saúde da Criança e do Adolescente}

\section{AVALIAÇÃO DO ESTADO NUTRICIONAL DE CRIANÇAS PORTADORAS DE CARDIOPATIAS CONGÊNITAS COM INDICAÇÃO CIRÚRGICA}

\author{
Maria Olímpia Ribeiro do Vale Almada \\ Orientadora: Profa. Dra. Jacqueline Pontes Monteiro \\ Dissertação de Mestrado apresentada em 11/02/2010
}

A cardiopatia congênita é definida como uma anomalia estrutural do coração e de seus vasos que ocorre durante a vida fetal e acomete cerca de $0,8 \%$ dos recém-nascidos vivos. A incidência é baixa, de, aproximadamente, $1 \%$ no Brasil e América Latina, e somente $0,1 \%$ ou $0,2 \%$ dos casos apresentarão situações ameaçadoras à vida no período neonatal. A 
cardiopatia congênita leva a uma série de alterações fisiológicas, como a inadequada ingestão alimentar, aumento do consumo de oxigênio, infecções respiratórios de repetição, insuficiência cardíaca, hipermetabolismo e à redução da absorção intestinal de nutrientes. Essas alterações influenciam diretamente o estado nutricional da criança, contribuindo para a subnutrição e o retardo do crescimento. O presente estudo teve como objetivos descrever o estado nutricional de crianças com cardiopatias congênitas (1 mês a 3 anos de idade) no pré-operatório de cirurgia cardíaca e comparar com crianças saudáveis. Para avaliação do estado nutricional, foi utilizado a antropometria (peso, estatura, prega cutânea triciptal e circunferência muscular do braço). Para avaliar a composição corporal foi utilizada a análise por diluição isotópica e a avaliação da ingestão alimentar, realizada através do recordatório 24hs. Participaram do estudo 18 crianças com cardiopatias congênitas de 1 a 34 meses de idade, submetidas à cirurgia cardíaca no Hospital da Clinicas de Ribeirão Preto, e 15 crianças saudáveis de 2 a 34 meses com acompanhamento de rotina no Centro Médico Social Comunitário Vila Lobato, cidade de Ribeirão Preto, São Paulo. O grupo das crianças com cardiopatias congênitas ingeriu consideravelmente mais carboidrato do que o das crianças saudáveis $(51,73+10,7$ x 42,7 $\pm 5,3$ p=0,006). Em relação ao peso $(7689,8 \pm 3095,2$ x 10016,5 $\pm 3084,9$ $\mathrm{p}=0,04)$ e à classificação de Gomez, as crianças doentes ) tiveram menores resultados do que as crianças saudáveis apresentando subnutrição $(81,69 \pm 10,49$ x 99,6 $\pm 11,96$ p=0,000), apenas duas crianças saudáveis apresentaram subnutrição grau I. Em relação à dobra cutânea triciptal, o grupo doente apresentou menor valor quando comparado ao grupo saudável $(6,97 \pm 1,56 \times 10,04 \pm 2,81$ p=0,000). Quando comparou-se os dados demográficos e as análises da composição corporal feitas pelo dentário os grupos foram semelhantes. A composição corporal e a antropometria não apresentaram diferenças estatísticas entre os dois grupos (doentes e saudáveis) nas crianças maiores de um ano de idade, porém as crianças com cardiopatias congênitas ingeriram menos proteína do que as crianças saudáveis $(45,72 \mathrm{~g} \pm 17,36$ x 79,91g \pm $16,58 \mathrm{p}=0,002)$. De acordo com a classificação de Gomez, as crianças menores de um ano de idade estavam mais subnutridas quando comparadas com as saudáveis $(77,60 \% \pm 10,88 \times 105,86 \% \pm 11,45 \mathrm{p}=0,000)$ e apresentaram piores valoresde massa gorda de acordo com avaliação realizada pela prega cutanea tricipital $(6,83 \mathrm{~mm} \pm 1,90 \times 10,92 \mathrm{~mm} \pm 3,10 \mathrm{p}=0,002)$ quando comparadas com o grupo controle. A ingestão de energia e de macronutrientes não apresentou diferença estatística. Os resultados mostram que os pacientes com cardiopatias congênitas com mais de um ano de idade são menos subnutridos do que as crianças doentes com menos de um ano de idade quando comparadas com crianças saudáveis. O método dos isótopos estáveis, utilizando o dentário, não detectou diferenças na composição corporal entre as crianças com cardiopatias congênitas e as crianças saudáveis, sendo a antropometria um método de avaliação mais prático e mais fácil para avaliar o estado nutricional (ou composição corporal) de crianças com cardiopatias congênitas.

\title{
USO DE INIBIDORES DE PROTEASE E ALTERAÇÕES DO LIPIDOGRAMA E DO ESTADO NUTRICIONAL DE CRIANÇAS E ADOLESCENTES INFECTADAS PELO VÍRUS DA IMUNODEFICIÊNCIA HUMANA (HIV-1)
}

\author{
Marina Hjertquist Tremeschin \\ Orientadora: Profa. Dra. Jaqueline Pontes Monteiro \\ Dissertação de Mestrado apresentada em 22/02/2010
}

Introdução e Objetivo: A proporção de mortes por Aids no Brasil, reduziu de forma significante, após a introdução da terapia antiretroviral de alta potência (HAART). Concomitante aos avanços no tratamento da Aids, foi identificado nos indivíduos adultos infectados pelo HIV, alterações morfológicas causadas pela exposição ao HAART como a lipodistrofia, caracterizada pela redistribuirão da gordura corporal, ocorrendo também hiperlipidemia. A terapia HAART é composta por três ou mais antiretrovirais (ARV), sendo o inibidor de protease (IP) frequentemente associado à lipodistrofia. Entretanto, existem poucos estudos clínicos no Brasil, sobre a associação do uso de IP com a síndrome da lipodistrofia, e seu impacto no estado nutricional de crianças e adolescentes, como existe em adultos. Dessa forma o objetivo do presente estudo é descrever e comparar as alterações do lipidograma e do estado nutricional em crianças e adolescentes infectados pelo HIV1 e em crianças e adolescentes HIV- negativo. Metodologia e Resultados: Trata-se de um estudo longitudinal no qual foram feitas avaliações antropométricas, de composição corporal, de ingestão alimentar e do lipidograma em 35 crianças e adolescentes, infectados pelo HIV-1 divididos em 3 grupos: Grupo 1 (G1) pacientes que não utilizam IP; Grupo 2 (G2) pacientes em uso de IP a mais de dois meses e Grupo 3 (G3) pacientes em uso de IP por um tempo menor ou igual a dois meses e em 16 crianças e adolescentes HIV - negativo, grupo 4 (G4), que foram avaliadas em dois momentos inicio do estudo (M0) e após doze meses de acompanhamento (M2) e comparadas entre si. Crianças e adolescentes infectadas pelo HIV em uso de IP (G2 e G3), apresentaram maiores níveis de triglicérides quando comparados ao grupo 4, no momento M0 $(\mathrm{p}=0,003)$ e no momento M2 ( $\mathrm{p}=0,004)$. Os níveis de HDL - colesterol apresentaram-se menores para os grupos 1 e 3 ) quando comparados ao grupo 4, no momento M2 (p=0,004). Após doze meses de acompanhamento, o grupo 2 apresentou 
os resultados mais baixos com relação aos parâmetros antropométricos e o grupo 4 os maiores, quando comparados aos grupos 1 e 3 . Os grupos 2 e 3 apresentaram pior índice estatura/idade e peso/estatura quando comparadas ao G1. O consumo de energia e macronutrientes foram similares entre os grupos. Na análise longitudinal não se observou nenhuma mudança no perfil lipídico para todos os grupos ( $\mathrm{p}>0.05$ ), exceto um aumento no HDL - colesterol para o grupo 4. Após doze meses de acompanhamento todos os grupos apresentaram melhora no estado nutricional, com aumento de massa corporal magra e gorda. Conclusão: Crianças e adolescentes infectados pelo HIV-1 apresentaram evolução nutricional deficiente quando comparadas ao grupo controle apesar de apresentarem similar ingestão alimentar. Crianças e adolescentes em uso de IP apresentaram maiores níveis de triglicérides, além de uma pior adequação das pregas cutâneas e da circunferência muscular do braço, evidenciando uma provável redistribuirão de gordura corporal e o estado clínico/ nutricional critico que esses pacientes se encontravam. Crianças e adolescentes infectados pelo HIV que não fazem uso de IP apresentaram uma eminente dislipidemia com diminuição estatística do HDL - colesterol.

\title{
HIPÓXIA SANGUÍNEA RELACIONADA A DOENÇAS RESPIRATÓRIAS AGUDAS E A REGULAÇÃO DO SISTEMA IGF EM CRIANÇAS
}

\author{
Rodrigo José Custodio \\ Orientador: Prof. Dr. Carlos Eduardo Martinelli Júnior \\ Tese de Doutorado apresentada em 23/02/2010
}

A hipóxia, relacionada à restrição do crescimento intra-uterino em animais, foi capaz de promover aumento na concentração sérica da IGFBP-1 sem alterações nas concentrações séricas de IGF-I. Além disso, a hipóxia grave provoca aumento na expressão do IGF1R de cones neuronais de crescimento dos fetos de ovelhas. Entretanto, em situações clínicas graves, houve redução das concentrações séricos do IGF-I e aumento da IGFBP-1 sérica. Porém, há pouca informação sobre a regulação do sistema IGF exercida pela hipóxia aguda em humanos. O objetivo desse estudo foi avaliar o sistema IGF e sua relação com a hipóxia aguda em crianças previamente normais. Para tanto foram dosadas as concentrações séricas de IGF-I, IGFBP-1, IGFBP-3 e insulina e quantificada a expressão do IGF1R em linfócitos de 27 crianças (14 meninos e 13 meninas) de 15 dias a 9,5 anos de idade com hipóxia aguda devida a problemas respiratórios e após sua recuperação, na mesma criança cujos valores são mostrados em médias ( \pm DP) emedianas $\mathrm{P}_{25} \mathrm{P}_{75}$. As concentrações de IGFI, IGFBP-1, IGFBP-3 e insulina foram determinadas por ELISA específico. Os linfócitos periféricos foram isolados de outras células utilizando Fycoll-Hypaque ${ }^{\circledR}$ e, após, o RNA foi extraído. A expressão do mRNA do IGF1R foi obtida mediante realização de RT-PCR em tempo real. As análises estatísticas foram realizadas por pareamento. A saturação de oxigênio foi $87,8( \pm 3,5) \%$ durante a hipóxia e $96,3( \pm 1,2) \%$ após recuperação ( $<<0.0001)$. Houve redução das concentrações séricas de IGF-I durante a hipóxia aguda: $21,3( \pm 37,8)$ e $60,2( \pm 58,6)$; e medianas de $12,3(6,24-20,14)$ e $54,8(24,51-72) \mathrm{ng} / \mathrm{ml}(\mathrm{p}<$ 0,0001); assim como das concentrações séricas da IGFBP-3: $1,53( \pm 0,8)$ e 2,34 $( \pm 0,7)$; e medianas de 1,32(0,86-2,17) e $2,25(1,9-2,78) \mathrm{mg} / \mathrm{l}(\mathrm{p}=0,0002)$. As concentrações séricas da ) IGFBP-1 aumentaram na hipóxia: $135,3( \pm 79,3)$ e 75,2 $( \pm 55,5)$; e medianas de $115,5(77,4-171,6)$ e $68,5(28,25-106,8) \mathrm{ng} / \mathrm{ml}(\mathrm{p}=0,0014)$. As concentrações séricas de insulina permaneceram inalteradas: $11,7( \pm 7)$ e 14,5 ( $\pm 9,6)$ e medianas de 9,1 $(8,48-11,1)$ e 9,8 $(8,79$ - 18,6) $\backslash 03 \mathrm{BCUI} / \mathrm{ml}$, nas situações de hipóxia e sem hipóxia $(\mathrm{p}=0,132)$, respectivamente. Houve aumento da expressão do IGF1R nos linfócitos onde as médias e medianas durante a hipóxia e sem hipóxia foram de 1,61 ( $\pm 1,26)$ e 1,21 ( $\pm 1,1)$; e de 1,28 (0,8 - 2,11) e 0,93 (0,41 - 1,7), respectivamente. Após Rareamento, houve diferença significativa na expressão do IGF1R entre as duas situações $(p=0,0373)$. Os dados apresentados, analisados em conjunto, sugerem que a hipóxia aguda, provavelmente, associada a fatores infecciosos, foi capaz de estimular alterações do sistema IGF com a redução do estímulo anabólico provocado pelo IGF-I e o aumento na expressão do gene codificador do IGF1R sugere um mecanismo compensatório de ativação tecidual.

\section{DETECÇÃO DA HIPOVITAMINOSE A E AVALIAÇÃO DAS CONCENTRAÇÕES PLASMÁTICAS DE VITAMINA E E IGF-1 APÓS DOSE TERAPÊUTICA DE VITAMINA A EM CRIANÇAS ATENDIDAS EM UMA UNIDADE DE SAÚDE}

\author{
Viviane Imaculada do Carmo Custodio \\ Orientador: Prof. Dr. Júlio César Daneluzzi \\ Tese de Doutorado apresentada em 23/02/2010
}

A vitamina A (VA) é uma substância lipossolúvel obtida através da dieta, sendo fundamental para a homeostase do organismo. Sua deficiência, mesmo em situação subclínica, é um sério problema de saúde pública, também no Brasil, 
podendo gerar sérios distúrbios às crianças, inclusive com repercussões para a vida futura. Uma vez que diversos estudos apontam para o papel da VA como um dos reguladores do crescimento e a associação frequente da deficiência de vitamina A (DVA) e de vitamina E (VE), principalmente em países em desenvolvimento, este trabalho verificou a ocorrência de deficiência de VE (DVE) através da dosagem de 103B1-tocoferol e de DVA através de comparação entre os métodos do retinol basal e dos testes de resposta à dose +S30DR (resposta sérica de 30 dias) e RDR (resposta relativa à dose). Além disso, foi verificada a influência da suplementação de VA com o estado de VE e IGF-1 em escolares. Para tanto, foi realizado estudo transversal, descritivo e prospectivo em 94 crianças saudáveis de 5 anos e 6 meses a 11 anos incompletos atendidas no CMSC de Vila Lobato (serviço de atendimento pediátrico primário vinculado à Faculdade de Medicina de Ribeirão Preto da Universidade de São Paulo). O +S30DR consiste na coleta de sangue para dosagem das concentrações de retinol sérico antes $A_{0}$ da suplementação com 200000 UI de palmitato de transretinil (PTR) por via oral e de uma nova coleta de sangue para a mesma dosagem 30-45 dias após $\left(\mathrm{A}_{30}\right)$ a suplementação. Para o cálculo do $+\mathrm{S} 30 \mathrm{DR}$, foi aplicada a fórmula $A_{30}-A_{0} A_{30} X 100$; resultados individuais $\backslash 226520 \%$ indicam baixas reservas hepáticas de VA. Para análise do retinol sérico foram utilizados os valores pré-suplementação $\mathrm{A}_{0}$; resultados inferiores a 1,05\03BCmol/1 foram considerados deficientes. Como "padrão ouro" foi utilizado o teste ) RDR, para tanto, foi administrado 1000\03BCg de PTR e colhido sangue no tempo zero $A_{0}$ e cinco horas após essa dose $A_{5}$ e aplicada a fórmula $A_{5}-A_{0} A_{5} \times 100$. Resultados positivos ( $(2265$ $20 \%$ ) são indicativos de DVA subclínica. A análise laboratorial do retinol sérico e do \03B1-tocoferol foi realizada através de HPLC, o IGF-1 foi mensurado através de ensaio imunorradiométrico. 5,3\% (5/94) e 24,5\% (23/94) das crianças apresentaram valores basais de retinol sérico respectivamente $<0,70 \backslash 03 \mathrm{BCmol} / 1$ e $<1,05 \backslash 03 \mathrm{BCmol} / 1$; testes RDR e +S30DR positivos foram observados em 20,2\% (19/94) e 28,2\% (27/94) dos sujeitos, respectivamente. Em relação ao RDR, o +S30DR apontou sensibilidade, especificidade, valor preditivo positivo e valor preditivo negativo de 84,2\% (IC 95\%: 76,8\%-91,6\%), 85,3\% (IC 95\%: 78,1\%-92,5\%), 59,3\% e 95,5\%, respectivamente. Os dados de sensibilidade, especificidade, valor preditivo positivo e valor preditivo negativo quando retinol sérico <1,05\03BCmol/1 foram respectivamente de 63,2\% (IC 95\%: 38,4\% - 83,7\%), 85,3\% (IC 95\%: 75,3\% - 92,5\%), 52,2 e 90,1\%, respectivamente. Sendo assim, o +S30DR mostrou-se superior para a detecção de DVA em relação ao retinol sérico, com a vantagem de ser também terapêutico. DVE foi encontrada em 7,5\% (7/94) das crianças. Houve incremento nos valores de IGF-1 e VE após a suplementação de VA nas crianças com DVA, não tendo havido alteração nas concentrações de IGF-1 e VE nas crianças sem DVA. Em relação ao IGF-1, tais resultados sugerem um possível papel da VA na regulação do crescimento. Em relação ao incremento dos resultados de VE nas crianças com DVA, pode-se supor que pelo menos parte do efeito anti-oxidante da VE deve ser mediado pela VA.

\title{
Saúde Mental
}

\section{CORRELATOS DE MORFOMETRIA BASEADA EM VOXEL DE IMAGENS DE RM COM MEDIDAS COGNITIVAS E FISIOLÓGICAS DO TESTE DE SIMULAÇÃO DE FALAR EM PÚBLICO NO ESPECTRO DE ANSIEDADE SOCIAL}

\author{
Maria Cecília da Silva Freitas \\ Orientador: Prof. Dr. José Alexandre de Souza Crippa \\ Tese de Doutorado apresentada em 19/02/2010
}

Introdução: Os limites diagnósticos do Transtorno de Ansiedade Social (TAS) são ainda controversos, uma vez que este transtorno poderia ser mais bem caracterizado dentro de um continuum de gravidade ao invés de uma condição qualitativa distinta. O presente estudo objetiva investigar as possíveis diferenças entre sujeitos pertencentes ao espectro da ansiedade social, utilizando a correlação entre o Teste de Simulação de Falar em Público (TSFP) e a morfometria cerebral de imagens adquiridas por ressonância magnética (RNM). Métodos: A amostra foi composta de estudantes universitários selecionados aleatoriamente com idades entre 18 e 25 anos. Foram incluídos pacientes com TAS (n=22), sujeitos com TAS subclínico (presença de temor de situações sociais sem evitação; $n=14$ ) e controles saudáveis ( $\mathrm{n}=25)$. Entre esses participantes, 46 indivíduos realizaram RNM estrutural: 17 pacientes com TAS; 14 sujeitos com TAS subclínico e 15 controles saudáveis. Em um primeiro momento, houve aplicação da TSFP, um modelo experimental de indução de ansiedade em humanos. Posteriormente, as medidas subjetivas e fisiológicas do TSFP foram correlacionadas com o volume de substância cinzenta cerebral, por meio da técnica de morfometria baseada em voxel (VBM). Foram considerados apenas clusters em regiões definidas a priori que tivessem uma significância para valores de Z maiores que 3,09 (correspondente a um limiar $\mathrm{p}<0,01$, não corrigido para múltiplas comparações). Tal limite de significância foi adotado também para as correlações. 
Resultados: Os achados no TSFP indicam que a evitação e os prejuízos funcionais constituintes do quadro de TAS estão mais ligados à autoavaliação negativa do que ao nível de ansiedade experimentada $(\mathrm{p}<0,001)$. Quando todos os grupos foram analisados juntos, houve correlação positiva entre os níveis de ansiedade e o volume da amígdala direita. A autoavaliação negativa de desempenho no teste foi associada a uma redução no volume do córtex cingulado anterior somente no grupo de pacientes com TAS. Conclusão: Os resultados sugerem que a associação entre ansiedade e volume da amígdala pode fazer parte de um continuum na ansiedade social. A associação entre a autoavaliação negativa de desempenho e a redução do volume do córtex cingulado anterior no grupo TAS é consistente com a hipótese de que esta área cerebral está envolvida no processamento de emoções negativas acessadas no TAS, mas não suporta a tese de que esta associação é parte de um continuum na ansiedade social.

\title{
EFEITO ANSIOLÍTICO DO CANABIDIOL NO FLUXO SANGUÍNEO CEREBRAL REGIONAL EM PACIENTES COM TRANSTORNO DE ANSIEDADE SOCIAL
}

\author{
Guilherme Nogueira Derenusson \\ Orientador: Prof. Dr. Jaime Eduardo Cecílio Hallak \\ Dissertação de Mestrado apresentada em 26/02/2010
}

O Transtorno de Ansiedade Social (TAS) apresenta com frequência baixo controle pelas medicações existentes; assim, parece clara a necessidade de pesquisa de novos agentes terapêuticos para o manejo deste transtorno. O consumo da Cannabis é comum em pacientes com TAS e relatos anedóticos sugerem que alguns pacientes usam esta droga para aliviar sintomas de ansiedade social. Estudos com animais e humanos têm mostrado que o canabidiol (CBD), um dos principais componentes da planta Cannabis Sativa, possui propriedades ansiolíticas, embora isto não tenha sido testado em casos de ansiedade patológica. O objetivo do presente estudo foi investigar esta droga em pacientes com TAS usando neuroimagem funcional e avaliar como seus efeitos são mediados no sistema nervoso central. Para tanto, o fluxo sanguíneo cerebral regional (FSCr) de repouso foi medido com o uso da tomografia por emissão de fóton único (SPECT), com traçador 99mTc-ECD, em 10 pacientes com TAS sem história de uso de drogas e tratamento, randomicamente divididos em dois grupos de 5 sujeitos. Cada sujeito foi avaliado em duas ocasiões, intercaladas pelo período de uma semana. Na primeira sessão, os sujeitos fizeram uso de CBD $(400 \mathrm{mg})$ ou placebo, em um procedimento duplo-cego. As imagens SPECT foram adquiridas 90 minutos após a ingestão da droga. A escala analógica visual do humor (VAMS) foi aplicada para avaliação dos estados subjetivos. Na segunda sessão, o mesmo procedimento foi realizado usando a droga que não havia sido administrada na sessão anterior. Comparações de FSCr entre as duas condições do mesmo sujeito foram realizadas para a confecção do mapa estatístico paramétrico (SPM). O CBD diminuiu significativamente a ansiedade sem acarretar sedação, enquanto o placebo não induziu mudanças significativas. A avaliação das regiões cerebrais onde os efeitos ansiolíticos do CBD foram preditos revelou inicialmente uma diminuição da captação de ECD na condição CBD em relação a placebo, com um agrupamento de voxel de significância ( $\mathrm{p}<0,001$, sem correção para múltiplas comparações) localizado no giro parahipocampal esquerdo e no hipocampo, estendendo-se para o giro temporal inferior. Um significante aumento ( $<<0,001$, sem correção para múltiplas comparações) na captação de ECD em relação à condição placebo foi também evidente no giro do cíngulo posterior direito. Não houveram outras regiões cerebrais preditas ou que mostrassem diferenças na captação de ECD entre as condições, com nível de significância p <0,001. Considerando a condição CBD, o SPM mostrou correlações negativas com o fator de ansiedade da VAMS revelando 2 agrupamentos de voxel (>20 voxels) que apresentaram nível de significância ( $\mathrm{p}<0,001$, sem correção para múltiplas comparações): um localizado à esquerda, outro localizado na amígdala direita. Estes resultados sugerem que o CBD tem propriedades ansiolíticas e que estes efeitos são mediados por uma ação em áreas cerebrais límbicas e paralímbicas.

\section{EFEITO DA ADIÇÃO DE NITROPRUSSIATO DE SÓDIO, UM DOADOR DE ÓXIDO NÍTRICO, AO TRATAMENTO ANTIPSICÓTICO HABITUAL DE PACIENTES COM DIAGNÓSTICO DE ESQUIZOFRENIA}

João Paulo Maia de Oliveira

Orientador: Prof. Dr. Antonio Waldo Zuardi

Dissertação de Mestrado apresentada em 19/03/2010

Introdução: Apesar de inúmeros estudos, a etiologia e fisiopatologia da esquizofrenia permanecem desconhecidas (embora muitas evidências científicas sugiram se tratar de um transtorno neuroevolutivo). Diversos trabalhos têm apontado para um possível papel do NO (óxido nítrico) na esquizofrenia. NO é um gás de química única que influencia a liberação de 
neurotransmissores, o aprendizado, a memória e o neurodesenvolvimento. Estudos recentes que investigaram o papel do NO em pacientes com esquizofrenia,sugerem um possível prejuízo na neurotransmissão mediada pelo NO neste transtorno. No presente trabalho, nós examinamos os efeitos do nitroprussiato de sódio, um doador de NO, como tratamento coadjuvante de pacientes com esquizofrenia. Materiais e Métodos: 20 pacientes adultos, de ambos os sexos, com esquizofrenia em tratamento antipsicótico habitual e em internação integral, foram divididos em dois grupos, que, receberam de forma randomizada a infusão por 4 horas de nitroprussiato de sódio ou placebo. Os sintomas psiquiátricos foram avaliados no início do experimento e a cada hora durante a administração da droga em estudo com a Escala de Avaliação Psiquiátrica Breve (BPRS) e com a subescala negativa da Escala de Avaliação de Sintomas Positivos e Negativos (PANSS). Adicionalmente, estes sintomas foram reavaliados 12 horas após a infusão, diariamente durante 7 dias e, em seguida, semanalmente até completar 4 semanas. Avaliação cognitiva (FAS, N-Back e Stroop) foi realizada antes e após 12 horas do experimento. Resultados: Vinte sujeitos completaram todas as fases do experimento. Quatro pacientes foram retirados do estudo devido a recusa em participar no dia do experimento. Nenhum efeito colateral foi reportado. Todas as características clínicas e demográficas dos pacientes, tais como idade, escolaridade, tempo de doença, gênero, subtipo diagnóstico e tipos de antipsicótico foram semelhantes nos dois grupos. O grupo nitroprussiato melhorou significativamente os escores de sintomas, mas não o grupo placebo (BPRS e PANSS). A performance cognitiva também melhorou significativamente no grupo nitroprussiato, mas não no grupo placebo (SCWTStroop Color Word Test e N-back). Não houve diferenças significativas entre os dois grupos quanto aos parâmetros fisiológicos analisados (pressão arterial sistólica, pressão arterial distólica, frequiência cardíaca e saturação de oxigênio). Conclusão: A estratégia em administrar 0,5 mcg/kg/min de nitroprussiato de sódio a pacientes com esquizofrenia em tratamento antipsicótico durante quatro horas foi bemsucedida. Nossos achados suportam a hipótese que a via "NMDA-NO-GMPc" esteja comprometida na esquizofrenia. Portanto, doadores de óxido nítrico, como o nitroprussitado de sódio, podem ser uma abordagem promissora para o tratamento da esquizofrenia. Apesar de animadores, estes resultados são preliminares e necessitam ser reproduzidos em estudos futuros.

\section{DOR, TEMPERAMENTO E PROBLEMAS DE COMPORTAMENTO EM CRIANÇAS COM QUEIXA DE DOR DE CABEÇA}

\section{Luciana Leonetti Correia}

Orientadora: Profa.Dra. Maria Beatriz Martins Linhares

Tese de Doutorado apresentada em 29/03/2010

A presente Tese teve por objetivo verificar a relação entre dor, temperamento e problemas de comportamento em crianças com queixa de dor de cabeça. Para a realização deste objetivo, foram desenvolvidos três objetivos específicos: 1) identificar a prevalência de dor em uma amostra de crianças cadastradas em Núcleos de Atenção Primária do Programa de Saúde da Família (PSF); 2) comparar dois grupos de crianças diferenciados em relação à presença de queixa de dor de cabeça, quanto a temperamento e problemas de comportamento e 3) identificar o melhor modelo de predição de queixa de dor de cabeça em crianças na fase préescolar. A amostra foi composta de 75 crianças e suas mães, as quais pertenciam a famílias cadastradas em Núcleos de Atenção Primária do PSF. De forma a atender ao segundo objetivo, a amostra foi distribuída em dois grupos, de acordo com a presença de queixas de dor de cabeça das crianças, que foi referida pela mãe, por meio do Questionário sobre histórico de saúde, queixa de dor e desenvolvimento da criança, sendo 22 crianças com queixa de dor de cabeça (Grupo CD) e 53 crianças sem esta queixa (Grupo SD). A coleta de dados foi realizada em visitas domiciliares com entrevistas com as mães. Na primeira entrevista foram aplicados a SCID Não- Paciente- Entrevista Clínica Estruturada para DSM III-R, o Questionário da Associação Brasileira de Estudos Populacionais, a Escala de Eventos Vitais, o Teste de Cefaléia e o Inventário de Sintomas de Stress para adultos de Lipp. Na segunda entrevista foram aplicados o Inventário de Comportamentos para as idades 1 1/2- 5 anos (CBCL for ages 1 1⁄2- 5), o Questionário de Comportamento da Criança (CBQ) e o Questionário sobre histórico de saúde, queixa de dor e desenvolvimento da criança. Foi realizada a análise de comparação entre grupos de crianças distribuídas de acordo com a presença de queixa de dor de cabeça referida pela mãe. A fim de identificar o melhor modelo de predição de queixa de dor de cabeça das crianças na fase pré-escolar, referida pela mãe, utilizou-se da análise de regressão logística. De acordo com os resultados, na análise de comparação entre grupos independentes, em relação ao temperamento, as crianças com queixa de dor de cabeça apresentaram significativamente mais desconforto quando comparadas as crianças sem esta queixa. Em relação aos problemas de comportamento, as crianças com queixa de dor de cabeça apresentaram significativamente mais problemas totais de comportamento, de internalização e externalização, sendo que os problemas totais e internalizantes apresentaram níveis de classificação clínica, quando comparadas às crianças sem esta queixa. As crianças do grupo com queixa de dor de cabeça apresentaram mais comportamento agressivo no eixo externalizante e, reação emocional, queixas somáticas e retraimento 
no eixo internalizantes, em relação às crianças do grupo sem esta queixa. A fim de verificar as variáveis preditoras da presença de queixa de dor de cabeça das crianças préescolares, foi testado um modelo de predição, utilizando-se a análise de regressão logística, o qual identificou a presença de sintomas de enxaqueca materna foi a melhor preditora da presença de queixa de dor de cabeça em crianças pré-escolares. Os achados apontam que crianças pré-escolares com queixa de dor de cabeça são vulneráveis a apresentarem mais queixas de dor e problemas de comportamento com classificação clinica quando comparadas às crianças sem esta queixa.

\title{
Saúde na Comunidade
}

\section{FORÇA MUSCULAR RESPIRATÓRIA RELACIONADA À QUALIDADE DE VIDA DE IDOSOS}

\author{
Aline Patricia Bonato Miranda \\ Orientador: Prof. Dr. Jair Licio Ferreira Santos \\ Dissertação de Mestrado apresentada em 26/01/2010
}

Nas últimas décadas o número de idosos é crescente, e este aumento da população em envelhecimento deve-se a diminuição da mortalidade, ao aumento da expectativa de vida e a diminuição da fecundidade, acompanhado pelas doenças crônicas, maior dependência e perda da autonomia. No entanto, a partir dos 50 anos de idade ocorre redução dos valores de pressão máxima inspiratória e expiratória. Sendo este diferencial pressórico que determinará a eficiência da tosse e consequente ocorrência de processos patológicos, como o acúmulo de secreção brônquica, levando a infecção pulmonar e consequente perda da qualidade de vida desses indivíduos. O presente trabalho teve por objetivo investigar a relação entre qualidade de vida e força muscular respiratória de indivíduos idosos. Trata-se de um estudo transversal descritivo e analítico, com abordagem quantitativa e foram analisados 55 indivíduos entre a faixa etária de 60 a 80 anos de idade. Os resultados evidenciam que a PImax diminui com a idade, não sendo encontrado significância estatística da PEmax em relação a idade, não havendo alteração entre os sexos, no entanto, este estudo sugere que a idade influência diretamente nos valores de PImax e PEmax ou seja, na força muscular respiratória (FMR), em ambos os sexos, principalmente nos homens. Conclui-se que há correlação entre a força dos músculos respiratórios e a qualidade de vida dos idosos, por isso é importante criar políticas públicas para essa faixa da população, promovendo infra-estrutura adequada para poder fazer frente às doenças limitantes, crônico-degenerativas, e consequentemente obter melhora da qualidade de vida dos idosos.

\section{AVALIAÇÃO DA ESTRATÉGIA SAÚDE DA FAMÍLIA EM UM MUNICÍPIO DE PEQUENO PORTE-MORRO AGUDO-SP, BRASIL}

\section{Daniel Moreira Pinto}

Orientadora: Prof ${ }^{\mathrm{a}}$. Dr ${ }^{\mathrm{a}}$. Aldaísa Cassanho Forster

Dissertação de Mestrado apresentada em 22/02/2010

Este estudo pretendeu avaliar a influência dos serviços prestados pela Estratégia Saúde da Família após sua implantação, no período de 2007 a 2008, utilizando indicadores de resultado.

Trata-se de um estudo de caso, com caráter exploratório-descritivo, centrando-se numa abordagem quantitativa. Para análise dos resultados da implantação da ESF do Município de Morro Agudo foram utilizados alguns indicadores de processo e resultado obtidos através do Sistema de Informação da Atenção Básica (SIAB) e de repercussões sobre o sistema local de saúde. Os dados levantados no período do estudo foram: Número de encaminhamentos para outros níveis de complexidade do sistema municipal ou regional de saúde, Número de contra-referência recebida de outros níveis de complexidade do sistema municipal ou regional de saúde, Número de Cesáreas, Número de Partos realizados, Referências da equipes de SF para internações hospitalares nas clínicas básicas, urgências e emergências, Total de casos novos de tuberculose bacilífera curados, Casos de hanseníase diagnosticados nos anos das coortes 2005 e 2004, e curados até 31/ 12/2008 e Número de óbitos femininos por causas maternas (obstétricas diretas, indiretas e não especificadas - 095) e outros utilizados na elaboração dos indicadores de saúde aprovados e monitorados no Pacto da Saúde (2006). 
A resolutividade foi $99,12 \%$ para o ano de 2007 e de $97,35 \%$ para o ano de 2008 , com uma diminuição em $11 \%$ da taxa de cesariana no período, observando-se também uma melhoria na maioria dos indicadores assistenciais.

A análise de cada um dos núcleos mostrou um incremento na produção assistencial, embora a recente implantação das Unidades de Saúde da Família não possibilitou perceber mudanças nos indicadores epidemiológicos da população da área.

O estudo concluiu que há necessidade de um período maior de monitoramento para observar mudanças sobre os indicadores de saúde, embora o processo assistencial já aponte algumas melhorias na utilização do sistema de saúde local.

\title{
ADAPTAÇÃO CULTURAL E VALIDAÇÃO DO INSTRUMETO GENÉRICO DE AVALIAÇÃO DE QUALIDADE DE VIDA COOP FUNCTION CHARTS
}

\author{
Gualter Santana Pedrini \\ Orientador: Prof. Dr. Antonio Ruffino Netto \\ Dissertação de Mestrado apresentada em 22/02/2010
}

Os profissionais da atenção primária, ainda hoje clinicamente orientada, apresentam dificuldade em entender o impacto que certas doenças provocam na vida de seus pacientes, além daquilo que já considerado sinal ou sintoma típico. Com o desenvolvimento de uma prática médica voltada para o paciente, aumenta cada vez mais o interesse por métodos de avaliação da qualidade de vida que fogem do modelo tradicional de mortalidade e morbidade que não penetram dentro da perspectiva do indivíduo diante de sua enfermidade. De fácil aplicação, o sistema COOP charts já foi traduzido e testado em vários países, sem uma versão brasileira. Assim sendo, realizou-se a tradução e adaptação cultural deste instrumento para o português brasileiro e, posteriormente, avaliou-se suas propriedades de medida. A tradução foi realizada por três profissionais bilíngues e a mesma foi aplicada em uma amostra de 30 pacientes duas vezes, até a obtenção de pelo menos 90\% de compreensão dos entrevistados em todos os itens. Para avaliar a reprodutibilidade interobservador, dois entrevistadores avaliaram 40 indivíduos de forma independente, no mesmo dia. Para a estabilidade temporal, 30 pacientes foram avaliados pelo mesmo entrevistador em dois momentos distintos, entre 12 e 14 dias. Tanto para avaliar o grau de concordância entre os avaliadores e esta estabilidade temporal foi utilizado o índice Kappa, sendo discriminado cada domínio. Para a consistência interna, foi realizado o cálculo do coeficiente de precisão Alfa de Cronbach para cada uma das categorias criadas em 70 entrevistas realizadas. A validação concorrente foi realizada comparando os resultados com o Medical Outcomes Study 36-Item Short-Form Health Survey (SF-36). Para tanto, os dois instrumentos sofreram adequações para que ambos possuíssem o mesmo número de domínios e a mesma forma de pontuação. O coeficiente Kappa também foi utilizado para avaliar a concordância entre os dois e foram entrevistados um total de 382 pacientes. Todo o processo de entrevista ocorreu na unidade do Programa Saúde da Família (PSF) da Água Comprida, na cidade de Bragança Paulista-SP, a faixa etária utilizada situou-se 18 e 65 anos. Na reprodutibilidade interobservador obteve-se coeficientes a partir de 0,76. Ao avaliar a estabilidade temporal, os valores obtidos apresentaram uma força de concordância que variou entre grande e perfeita (0,69 - 1,00). Para a consistência interna o cálculo do coeficiente de precisão Alfa de Cronbach global foi de 0,71 , a exclusão de cada domínio, provocou reduções significativas nos valores calculados, exceto o domínio D5, o que pode apontar para o fato de que a escala deveria ser utilizada sem subdivisões ou a exclusão de itens. Na avaliação da validade concorrente foi obtida uma força de concordância também quase perfeita. A adaptação transcultural do COOP charts para o português, bem como a demonstração de sua confiabilidade e validade, tornam este instrumento um elemento adicional para ser usado de forma genérica, tanto em pesquisas como na prática clínica rotineira.

\section{AVALIAÇÃO DA ASSISTÊNCIA PRÉ-NATAL ÀS GESTANTES ADOLESCENTES DE UM MUNICÍPIO PAULISTA}

\author{
Ana Cláudia da Silva Paschoal \\ Orientadora: Prof ${ }^{\mathrm{a}}$. Dra ${ }^{\mathrm{a}}$. Elisabeth Meloni Vieira \\ Dissertação de Mestrado apresentada em 26/02/2010
}

Trata o presente estudo de uma avaliação da assistência pré-natal oferecida pelo serviço municipal de saúde a gestantes adolescentes, residentes no município de Franca, estado de São Paulo, para saber se esta cumpre os protocolos estabelecidos pela Portaria GM/MS nº 569 de $1^{\circ}$ de junho de 2000, do Ministério da Saúde, para o atendimento da gestante em todo ciclo gravídico-puerperal. É um estudo com referencial teórico da avaliação de serviços de saúde, utilizando o 
indicador de processo para descrever como a assistência está sendo prestada às gestantes adolescentes inscritas no SISPRENATAL no município de Franca (SP), nos anos de 2006 e 2007. Foram usados como ferramentas essenciais os dados estatísticos alimentados no sistema de informação, utilizando como critérios os indicadores apontados pelo Ministério da Saúde. Os resultados, nos itens priorizados para a avaliação, indicam precariedade no serviço prestado. A análise sugere que a assistência oferecida à gestante é de baixa qualidade, em particular à adolescente grávida. Nos resultados destaca-se: 81,7\% das gestantes adolescentes iniciaram o acompanhamento de PN antes de 120 dias de gestação, contudo realizam-se em média 4,4 consultas durante o PN, e apenas para 32,8\% delas foi cumprido o protocolo de realização de no mínimo seis consultas de PN. Quanto à distribuição da realização dos exames laboratoriais durante o PN, foi verificado que em média $77 \%$ das gestantes adolescentes tiveram exames realizados na primeira consulta e que somente $28,8 \%$ tiveram seus exames repetidos dentre a $28^{\mathrm{a}}$ e $30^{\mathrm{a}}$ semana de gestação. Observou-se que uma pequena parcela $(6,7 \%)$ de gestante realizou a consulta puerperal antes de completarem 42 dias de pós parto e que a maioria $(84,9 \%)$ se concentra na consulta puerperal após 42 dias de pós parto. Em relação à imunização contra o Tétano, foi verificado que apenas 51,9\% encontravase imunizada ou que já havia recebido a dose de reforço da vacina Dupla adulto. A discussão em torno dessas diferenças possibilitou ao término do estudo, concernir que o município de Franca (SP), enquanto fornecedor de dados ao sistema SISPRENATAL, nos anos considerados não teve êxito. Portanto, é pertinente que se realize a avaliação do processo nos anos subsequentes bem como as ações necessárias para a melhoria deste quadro. 